

UNIVERSIDADE DE BRASÍLIA - UnB

FACULDADE DE EDUCAÇÃO FÍSICA - FEF

PROGRAMA DE PÓS-GRADUAÇÃO EM EDUCAÇÃO FÍSICA

MESTRADO EM EDUCAÇÃO FÍSICA

\title{
A CORPOREIDADE DE JOVENS CATÓLICOS PERTENCENTES À RENOVAÇÃO
} CARISMÁTICA

LETÍCIA RODRIGUES TEIXEIRA E SILVA 
A CORPOREIDADE DE JOVENS CATÓLICOS PERTENCENTES À RENOVAÇÃO CARISMÁTICA

LETÍCIA RODRIGUES TEIXEIRA E SILVA

Dissertação apresentada à Faculdade de Educação Física da Universidade de Brasília, como requisito parcial para obtenção do grau de Mestre em Educação Física, na área de Estudos Sociais Pedagógicos da Educação Física, Esporte e Lazer. Defendida em 05/08/15.

ORIENTADORA: PROF . DRª . DULCE MARIA FILGUEIRA DE ALMEIDA 
Ficha catalográfica elaborada automaticamente,

com os dados fornecidos pelo(a) autor(a)

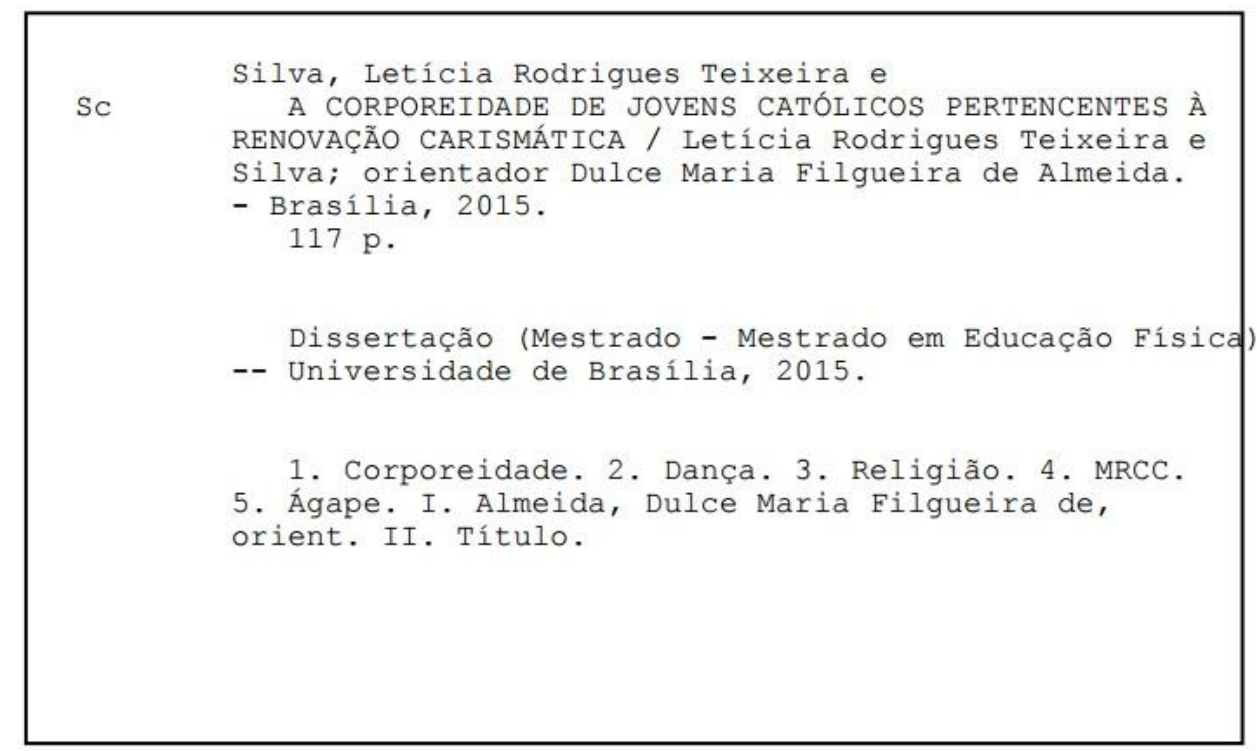




\section{BANCA EXAMINADORA:}

Prof ${ }^{\text {a. }}$ Dra . Dulce Maria Filgueira de Almeida

Universidade de Brasília - FEF/UnB

Profá. Dra ${ }^{\text {a }}$ Larissa Michelle Lara

Universidade Estadual de Maringá - FEF/UEM

Prof. Dr. Luiz Renato Vieira

Senado Federal

Prof. Dr.Tadeu João Ribeiro Baptista

Universidade Federal de Goiás - FEF/UFG

Brasília, 05 de agosto de 2015. 
Para quê os versos se não há quem os ouçam Para quê os elogios se não há quem os recebam Para quê o sorriso se não há alegria Para quê as lágrimas se não há sentimentos

Para quê as mãos se não as usamos

Para quê discursos se não há quem influir Para quê memórias se não há boas recordações Para quê as flores se não há quem as olhem Para quê milagres, se não acreditam na vida

Não somos máquinas, somos humanos, Há um coração que pulsa em nós, Por debaixo de nosso peito O sangue corre em nossas veias, Temos o poder de criar, de produzir e executar Descubra a magia de viver

(Receita para a paz do mundo - Sentido contrário) 


\section{AGRADECIMENTOS}

À minha família, Mãe, Pai e Dudu, por me apoiar nessa etapa. Tia Zezé, Vovó e Madrinha Márcia, as quais são detentoras de uma forte espiritualidade cristã (cada uma ao seu modo), estiveram sempre perguntando e se informando sobre a pesquisa. Alline, Isadora, Isabela, Brunno, Lúcio e Tio Edinaldo, pelos momentos de descontração. Lucas por sempre requisitar minha presença. Tio Beto e Sandra, por me auxiliarem quanto a estadia em Brasília (também a Sigla Engenharia, em especial Francis e Hetyenne).

Aos amigos: Patrícia e Jaira, tenho orgulho de nossa amizade. Clara e Júlia, a vocês agradeço em especial pelos momentos compartilhados nas salas de musculação. A todos STT, à turma que se formou comigo no curso de Educação Física da UEG, especialmente por continuarmos unidos com o passar do tempo e comemorarmos juntos as conquistas uns dos outros. Ao Necon, Imagem, COEESA, tenho orgulho de dizer que amizades foram construídas dentro desses grupos. Também aos colegas de Pós-Graduação. Em especial, aos mais próximos: Marisa, Cláudio, Tayanne, Thaís, Thainá, Mayrhon, Nadson (que é do AVANTE), Sissília e Tadeu.

Às minhas ex-professoras, Cristina Bonetti e Cida Telles, por me fornecer materiais a respeito da dança e religiosidade.

À Dulce, por me orientar nessa trajetória acadêmica e, sobretudo, pelo incentivo e buscas aos olhares diferentes. Sou muito grata por tudo que aprendi nesses anos sob sua orientação.

À professora Ingrid, por ter sido tão especial durante o mestrado.

À Capes, pela concessão da bolsa de estudo.

Aos funcionários Alba, Quélbia, Tiago, Josino e Maria pela prontidão e compreensão. A todos do Grupo de Oração Ágape, em especial, Thaíssa e Valtônio. A todos aqueles que colaboraram para a realização deste trabalho. 


\section{SUMÁRIO}

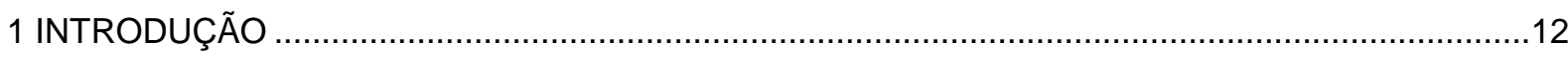

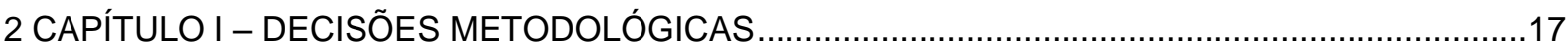

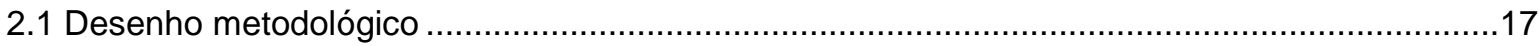

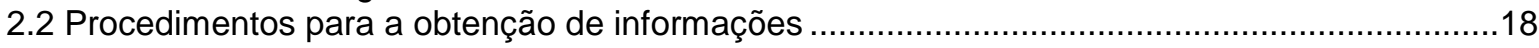



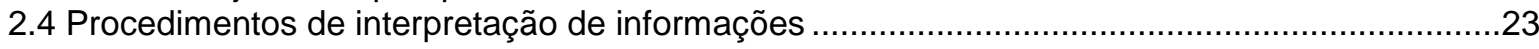

3 CAPÍTULO II - SENDO ÁGAPE: O COTIDIANO DE ECOS DE VOZES DESTOANTES EM

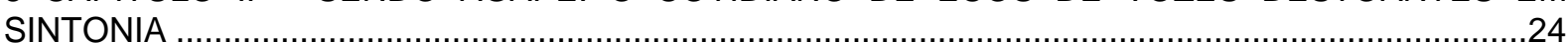

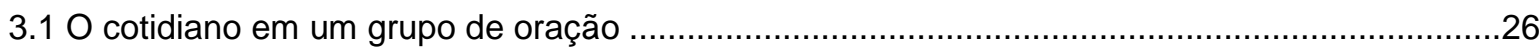

3.2 O encontro dos servos: a formação de elos entre ecos de vozes destoantes ............................27

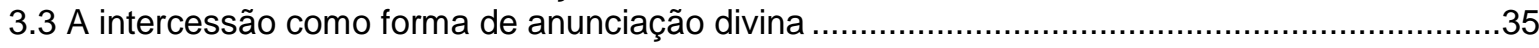

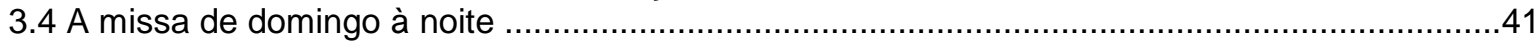

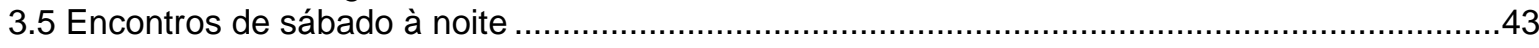

4 CAPÍTULO III - COM DANÇAS GLORIFIQUEM O SEU NOME ....................................................48

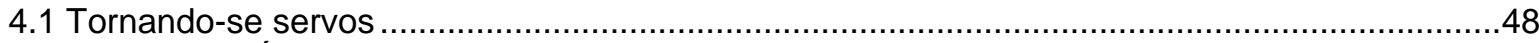

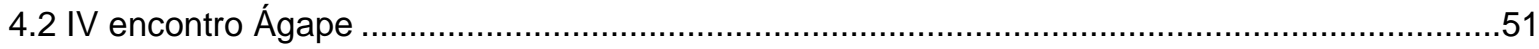

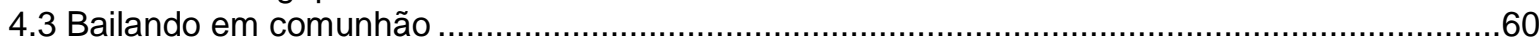

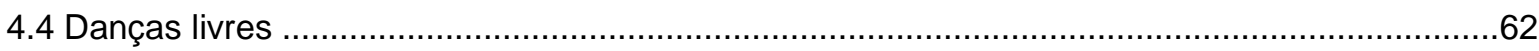

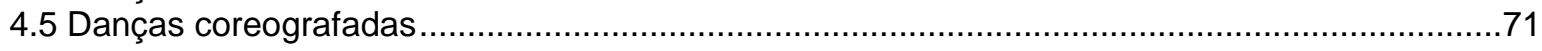



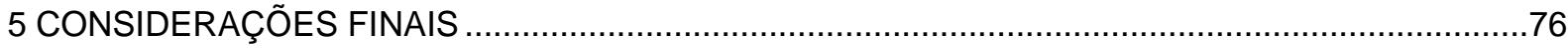

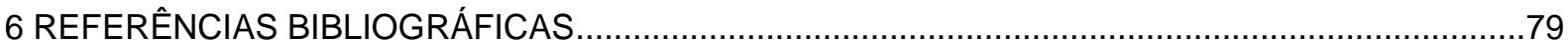






\section{RESUMO}

O objetivo deste estudo é compreender o significado da vivência da corporeidade dos jovens do movimento católico carismático, considerando a dança como uma prática corporal que pode possibilitar processos de interação social e a relação com o sagrado. Para tanto, realizou-se uma pesquisa de campo de inspiração etnográfica, utilizando-se da descrição densa dos fatos da forma que propõe Geertz (1989). Como procedimentos para a obtenção de informações, foram utilizadas a observação (registrada por diário de campo) e entrevista semipadronizada. O Grupo Ágape, da Paróquia Sagrada Família, Vila Canaã de Goiânia-GO foi escolhido por atender ao critério definido no objetivo da pesquisa. Os resultados apontaram que o significado da corporeidade dos jovens do grupo evidencia práticas corporais de diversas naturezas e tem por objetivo a busca pelo sagrado. Dentre as práticas corporais verificadas, a saber: o repouso no espírito, a glossolalia, as danças livres e as danças coreografadas; as danças assumiram um papel destacado nas atividades do grupo Ágape. A relevância das danças se deu por dois fatores: (I) por expressarem uma manifestação corporal que promove a interação social entre os participantes e, (ii) pela clara relação que se estabelece entre sagrado e profano na dança. Nesse caso, a eficácia e a tradição presentes na prática corporal, fazem uso de técnicas corporais, com a finalidade de alcançar a transcendência, a vivência mítica - do ponto de vista do sagrado e, a fuga do cotidiano, a socialização, a alegria e a afetividade - relacionadas aos aspectos profanos da prática corporal. Concluiu-se que é por meio da corporeidade e, sobretudo por meio da dança, que os jovens do Ágape estabelecem processos de interação social e a busca pelo sagrado.

Palavras-chave: Corporeidade. Dança. Religião. MRCC. Ágape. 


\begin{abstract}
This study aims at understanding the meaning of the experience of embodiment of the youth in the charismatic catholic movement, considering dance as a bodily practice that facilitates processes of social interaction and relationships with the sacred. It relies on field research of ethnographic inspiration, using the dense description of facts proposed by Geertz (1989). The data survey procedures were observation (registered in a field journal) and semi-standardized interviews. We chose the Agape Group of the Sacred Family Parish, in Vila Canaã, in the city of Goiânia - GO as it fit the criteria defined for the research goal. Results indicate that the meaning of embodiment for the youth in the group evince bodily practices of diverse natures and aim at the search for the sacred. Among the identified bodily practices, namely: meditative resting, glossolalia, freestyle dancing and choreographed dancing, dancing had a prominent role in the Agape activities. The relevance of dancing stems from two factors: (i) for expressing a bodily manifestation that fosters social interaction among the participants and (ii) for the clear relationship between sacred and profane in dancing. In this case, the efficacy and tradition present on the bodily practice are invested with body technique, with the aim of achieving transcendence, the mythical experience - from the perspective of the sacred, as well as an escape from daily life and embrace of socialization, joy and affection connected to the profane aspects of the bodily practice. The conclusion is that embodiment on charismatic dance establishes social interaction in the search for the sacred.
\end{abstract}

Keywords: Embodiment. Dance. Religion. CRRM. Ágape. 


\section{LISTA DE TABELAS}

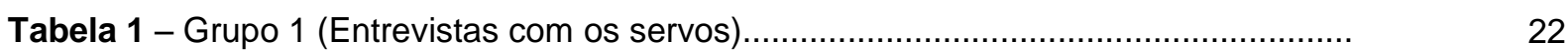

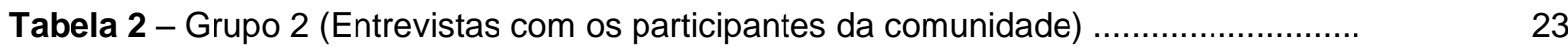

\section{LISTA DE FIGURAS}

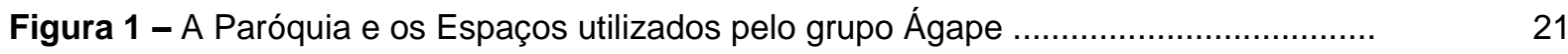

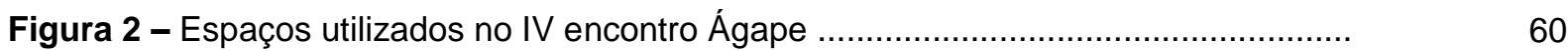




\section{LISTA DE ABREVIATURAS E SIGLAS}

$\begin{array}{lll}\text { ACM } & - & \text { Associação Cristã de Moços } \\ \text { EUA } & - & \text { Estados Unidos da América } \\ \text { FEF } & - & \text { Faculdade de Educação Física } \\ \text { NECON } & - & \text { Núcleo de Estudos sobre Corpo e Natureza } \\ \text { MRCC } & - & \text { Movimento da Renovação Carismática Católica } \\ \text { RCC } & - & \text { Renovação Carismática Católica } \\ \text { UFG } & - & \text { Universidade Federal de Goiás } \\ \text { UnB } & - & \text { Universidade de Brasília } \\ \text { UEM } & - & \text { Universidade Estadual de Maringá }\end{array}$




\section{INTRODUÇÃO}

Estudos sobre o corpo compreendem as lógicas sociais e culturais que envolvem a extensão e os movimentos do homem (LE BRETON, 2012). Na Educação Física, em particular, os estudos acerca do corpo se tornam cada vez mais importantes, sobretudo, aqueles que põem a dança no centro da investigação entendida assim como prática corporal (KUNZ, 2010). A dança é um fenômeno sociocultural, cuja prática se conforma em diferentes espaços e tempos sociais. Na dança ou por meio dela, os seres humanos socializam-se, brincam, divertem-se, integram-se e também oram. A propósito, ainda pouco estudada no campo da Educação Física, a dança como oração ou louvação é um fenômeno social que se manifesta em diferentes contextos religiosos.

Enquanto prática corporal, a dança pode ser entendida como um fato social total, pois está revestida de aspectos biológicos, psicológicos e também sociais (MAUSS, 2003). Com efeito, no entendimento de Mauss (2003), há a necessidade do desenvolvimento de estudos em diferentes áreas do conhecimento, que possibilite e articule uma maior relação entre elas. É exatamente sob essa perspectiva relacional que essa pesquisa está assentada, a saber, pela aproximação entre as Ciências Sociais (Sociologia e Antropologia) e a Educação Física.

O presente trabalho tem por objetivo compreender os sentidos/significados da experiência da corporeidade entre jovens do movimento católico carismático. Parte-se do princípio de que a dança possibilita processos de interação social e estreita relação com o sagrado. Ademais, essa pesquisa é fruto de uma inquietação científica e também pessoal, a qual passo a relatar. Tudo começou quando, ainda com quatorze anos de idade, inscrevi-me no curso preparatório para o sacramento da crisma. Naquele momento, senti o desejo de participar de modo ativo da comunidade católica. Esse curso foi realizado na Paróquia Sagrada Família de Goiânia, estado de Goiás. Na oportunidade, o curso era coordenado por um pároco do movimento católico carismático e por catequistas que também faziam parte do MRCC. A partir de então, passei a conhecer cada vez mais pessoas e me inteirar dessa manifestação religiosa. Terminado o curso, entre os quinze e os dezenove anos, meu envolvimento com o MRCC crescia paulatinamente. Participei ativamente de vários eventos típicos da RCC, como os seminários de vida no Espírito, rebanhões, raves católicas e carnavais com Cristo, eventos estes regados à dança e oração.

A imersão nesse universo provocou em mim a necessidade de continuar na vida religiosa de um modo mais intenso, tanto que aos dezoito anos fui viver em um convento como aspirante à vida religiosa, quase me tornei noviça. Todavia, aos poucos fui entendendo que aquela decisão havia sido precipitada, então decidi ingressar no curso de Educação Física.

No curso de Educação Física, aproximei-me de discussões relacionadas à corporeidade, e passei a investigar essa temática por meio das concepções de corpo de alunos do próprio curso. 
Temática esta que continuaria objeto de meu interesse durante o Mestrado, porém com um novo recorte. Agora, minha intenção seria entender a relação da corporeidade com aspectos religiosos relacionados à dança no MRCC.

A busca por relacionar o campo de pesquisa da Educação Física com minha experiência pessoal religiosa foi determinante para a escolha do meu tema de investigação. Sobretudo, porque havia vivenciado na prática - recordei-me dos rebanhões, das raves católicas e carnavais com Cristo, e de pronto identifiquei ser a dança um importante fenômeno que se interpunha entre a corporeidade e a juventude católica. Em suma, o desejo em estabelecer a dança como recorte da pesquisa fez com que eu recordasse alguns momentos de minha experiência religiosa, no seio dessa religião. Isso porque a dança, além de ser um ofício a ser desenvolvido no âmbito do catolicismo, fazia parte de vários momentos de oração cotidiana.

Um exemplo marcante, a fim de situar a importância da dança como louvação, está apresentado em um trecho do Salmo 140, que assim diz:

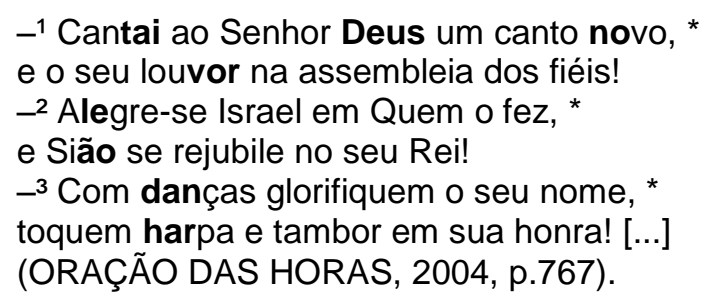

Como se percebe da "Oração das Horas", que leva esse nome exatamente por se constituir por um conjunto de orações a serem realizadas ao longo do dia e que costumava ser feita aos domingos, a dança em sua ladainha é tratada como a alegria do povo de Deus ${ }^{1}$. A oração é, pois, uma convocação para a dança, que deve ser realizada alegremente, com júbilo, em um ato de louvor a Deus e para a glória de seu nome.

No catolicismo, assim como deve ocorrer em outras religiões, as orações são direcionadas conforme o tempo litúrgico, a saber: advento, natal, tempo comum, quaresma e páscoa. Os católicos devotos são orientados a orar, independente de seu chamado vocacional. Algumas orações são mais conhecidas dentro de determinadas comunidades religiosas (sejam elas de vida $^{2}$ ou de celibato ${ }^{3}$ ), como as orações do livro das horas, as quais são regadas de fragmentos da Bíblia.

Especificamente no contexto do MRCC, Maués (2007) realizou pesquisa sobre a influência da dança nos grupos de oração. Segundo o autor, a dança nesse universo pode ser inclusive

\footnotetext{
'Havia outra oração, denominada "louvai o Senhor" (Salmo 150), que também citava a dança, mas era rezada esporadicamente em minha congregação religiosa.

${ }^{2}$ As comunidades de vida permitem o casamento entre pessoas que se reúnem, a fim de viver uma vida espiritual mais concentrada.

${ }^{3}$ As comunidades celibatárias não permitem o casamento, mas assim como nas comunidades de vida, as pessoas se reúnem em uma comunidade buscando uma vivência espiritual mais profunda.
} 
coreografada, constituindo-se, portanto, como uma das técnicas corporais que propicia um clima de fraternidade, alegria e congraçamento entre os participantes e os auxilia a se encontrarem com o sagrado.

Caldeira (2008), por seu turno, aponta que uma característica importante da dança em contextos religiosos é a de ser um ato coletivo, que favorece o processo de socialização entre os participantes do louvor. Em outras palavras, pode-se dizer que a dança propicia a maior interação social entre os participantes de um ato religioso. Maués (2007), Silveira (2011) e Bianconi (2008), evidenciam em seus estudos que a RCC favorece a vida cotidiana partilhada com os outros, ou seja, a interação social. Por esta razão, tanto Silveira (2011) quanto Bianconi (2008) comungam da ideia segundo a qual uma nova corporeidade é construída pelo modo como a RCC propõe a realidade partilhada.

A prática corporal da dança, constituída por seu conjunto de técnicas corporais, ajuda a retratar um universo cultural. Ela possui em sua própria bagagem tradições, histórias, estilos e conhecimento, que, por seu turno, constitui-se por um aprendizado contínuo ao envolver a música, o ritmo, a técnica de movimento, a dialética do movimento e o espaço físico (ambiente) (SARAIVA et al., 2005). Como parte da cultura, a dança em menor grau é um sinal da deidade cristã ou até mesmo a incorporação dela, quando o corpo que dança remete-se ao sagrado. O homem, para Eliade (2008), toma reconhecimento do sagrado porque este se manifesta. No caso dos carismáticos, essa manifestação se dá no próprio corpo. Encontra-se no corpo dos carismáticos uma "manifestação de algo 'de ordem diferente' de uma realidade que não pertence a nosso mundo" em corpos que fazem parte integrante de nosso mundo natural (ELIADE, 2008, p.17).

Contudo, embora possam ser pontuadas algumas relevantes pesquisas sobre a dança em contextos religiosos, e algumas delas realizadas em periódicos da Educação Física, identificou-se apenas quatro trabalhos que continham os termos de busca "corpo", "dança" ou "religião", como palavras-chave e que, ao mesmo tempo, no decorrer do texto, mencionavam os três assuntos em correlação. Os trabalhos são os de Lara (1999a e 2000), Bianconi (2008) e Rigoni e Prodócimo (2013).

Em suas pesquisas, Lara (1999 e 2000) dá um enfoque maior às questões da dança no Candomblé, considerando-a como expressão da cultura religiosa. Já Rigoni e Prodócimo (2013), analisam as práticas corporais em uma igreja pentecostal (evangélica), sendo o corpo um instrumento de expressão da fé. Bianconi (2008), por sua vez, aborda o movimento religioso católico com enfoque na corporeidade como um elemento de reflexão para o campo da Educação Física, sendo a dança um dos vários elementos que constituem a corporeidade entre os católicos carismáticos. Apesar de

\footnotetext{
${ }^{4}$ Uma vez que os estudos sobre o corpo são recentes e não há consenso na literatura sobre o termo que se deve utilizar, a palavra corpo foi aqui selecionada. Muitas vezes, ao tratar sobre o corpo os autores retratam a corporeidade.
} 
lançarem olhares que realizam a triangulação entre corpo, dança e religião, e ainda delinear suas análises no contexto da Educação Física, esses autores não apresentam o recorte sobre a dança praticada por jovens da Renovação Carismática Católica.

Em outro âmbito, porém não menos importante, as publicações da base de dados do Núcleo Brasileiro de Dissertações e Teses - NUTESES ${ }^{5}$ também apresentam um número relativamente pequeno de estudos, pois em um período compreendido entre 1982 e 2006 foram encontrados apenas onze estudos que continham de alguma forma a palavra "religião", estudos esses que se distribuíam entre sete dissertações e quatro teses. Em contrapartida, com a palavra "dança" foram encontrados 316 trabalhos e 828 com a palavra "corpo". Ou seja, a escassez de estudos sobre a temática, sobretudo quando relacionada ao MRCC com a corporeidade e a dança, ajuda a dar relevância à pesquisa.

Em um panorama mais restrito, nesse caso no âmbito da Universidade de Brasília, evidenciado os trabalhos de pesquisa desenvolvidos por pesquisadores do Núcleo de Estudos sobre Corpo e Natureza - NECON ${ }^{6}$, observou-se que dos trabalhos em nível de mestrado, apenas três deles não foram desenvolvidos com foco no corpo, na dança ou na religião. Dos que tratam desse assunto, cinco já foram concluídos, são eles Almeida (2008), Santos (2011), Terra (2013), Santos (2013), Silva (2014), o que contribui para fortalecer a linha de pesquisa sobre "estudos das práticas corporais, cultura e natureza", a qual a presente pesquisa se vincula.

No delineamento desse cenário, pergunta-se "qual é o significado da vivência da corporeidade dos jovens do movimento católico carismático, considerando a dança como uma prática corporal que possibilita processos de interação social e a relação com o sagrado?"

Essa pesquisa tem a intenção de compreender a vivência da corporeidade dos jovens do MRCC, tendo como recorte a dança. Para tanto, realizou-se um trabalho de orientação etnográfica junto ao grupo de oração Ágape, grupo pertencente à doutrina católica da Renovação Carismática. Vinculada à Igreja Sagrada Família, a pesquisadora participou em diferentes momentos da constituição desse grupo.

Com efeito, tem-se clara a ideia de que o envolvimento com o grupo apresenta pelo menos dois vieses que merecem destaque. O primeiro é familiaridade, que contribuiu para abrir caminhos,

\footnotetext{
${ }^{5}$ NUTESES é um núcleo brasileiro de dissertações e teses, ou melhor, um centro de informação online que disponibiliza digitalmente uma gama de produções de mestrado e doutorado, que se encontram nas áreas da Educação, Educação Física e Educação Especial, concluídas tanto no Brasil quanto no exterior.

6 O NECON é um grupo liderado pela professora doutora Dulce Maria Filgueira de Almeida. Desenvolve estudos e pesquisas voltados às práticas corporais no campo das Ciências Sociais, vinculados, sobretudo, à Sociologia. O funcionamento do grupo ocorre na Faculdade de Educação Física, da UnB e acolhe estudantes de várias áreas, em especial, da Sociologia, Antropologia e Educação Física.
} 
pois, na condição de participante do grupo, tive conhecimento das lideranças, dos procedimentos, locais, horários, enfim, aspectos de ordem burocrática e social, que possibilitaram a realização da pesquisa. O segundo viés diz respeito à necessidade de se tornar "vigilante" dos próprios procedimentos de pesquisa, no momento de aproximação e inserção em campo. Aqui, usei do artifício da vigilância epistemológica, com o objetivo de assegurar o controle dos vieses/bias na pesquisa, desenvolvendo os cuidados necessários, buscando sempre uma relação realista com a prática científica, lidando com a subjetividade do pesquisador, a fim de que a mesma não viesse a modelar as informações obtidas em campo (GOLDENBERG, 2004). Utilizou-se de vigilância epistemológica: o cuidado permanente com as condições e os limites da legitimidade de técnicas e conceitos. As atitudes de repensar cada passo da pesquisa, mesmo a mais rotineira e óbvia (BOURDIEU et al., 1990).

Assim sendo, no primeiro capítulo deste trabalho estão as questões metodológicas. O desenho metodológico explicita as decisões tomadas quanto ao tipo da pesquisa, os procedimentos relativamente às informações, lócus e sujeitos da pesquisa e a interpretação das informações. No segundo capítulo, discorreu-se sobre o cotidiano do Ágape, sendo apresentadas as técnicas corporais realizadas por seus participantes. No terceiro capítulo, estão as danças propriamente ditas, evidenciando a interação social e relação entre o sagrado e o profano. Por fim, as conclusões. 


\title{
CAPÍTULO I - DECISÕES METODOLÓGICAS
}

\subsection{Desenho metodológico}

Os passos de uma pesquisa de orientação qualitativa são, de acordo com Flick (2009), fundamentais para traçar caminhos pretendidos no âmbito das Ciências Sociais. Ao se trabalhar na fronteira entre a Educação Física e a Sociologia, essa pesquisa ancorou-se no arcabouço sociológico para delinear o seu método de investigação.

Traçado o caminho a ser perseguido, o método atende a etapas, que se forem bem delimitadas e claras, possibilitarão o alcance dos objetivos propostos para a investigação. Todavia, o passo-a-passo da pesquisa não é tão simples e fácil como se imagina à primeira vista. Até que a pesquisa se inicie, muitas etapas a precedem. Primeiro, a construção do projeto de pesquisa, na sequência a aprovação pelo Comitê de Ética em Pesquisa ${ }^{7}$, depois a autorização para realizar e dar início à pesquisa, enfim, o contato com o grupo a ser estudado e a imersão em campo. Entre a defesa do projeto e a finalização do trabalho, a pesquisa dura meses, às vezes, anos, e o tempo passa a ser nosso maior inimigo, pois é chegada a hora da defesa. Portanto, chegar até aqui, não é nada fácil. Porém, optamos por seguir esse caminho, realizar uma pesquisa de natureza qualitativa.

\begin{abstract}
A pesquisa qualitativa dirige-se à análise de casos concretos em suas peculiaridades locais e temporais, partindo das expressões e atividades das pessoas em seus contextos locais. Consequentemente, a pesquisa qualitativa ocupa uma posição estratégica para traçar caminhos para que as ciências sociais, a psicologia e outras áreas possam concretizar as tendências [...], mantendo a flexibilidade necessária em relação a seus objetos e tarefas (FLICK, 2009, p. 37).
\end{abstract}

Autores há, como Flick (2009), que acreditam poder a pesquisa qualitativa fornecer condições substancialmente suficientes para a compreensão de certas peculiaridades, notadamente aquelas expressas pela corporeidade dos jovens que frequentam o grupo Ágape do MRCC, assim como possibilitará a análise da dança praticada pelos fiéis, proporcionando a flexibilidade necessária para realizar possíveis análises.

A consideração das condições supracitadas é por si só suficiente para permitir um estudo de campo de matiz etnográfica à questão da corporeidade; de fato, basta reparar a densa descrição dos fatos, tal qual preconizada por Geertz (1989). A posição de Angrosino (2009) é de adesão aos métodos etnográficos, os quais são satisfatoriamente empregados para estudar comportamentos sociais que ainda não foram claramente compreendidos. São usados também quando importante for

\footnotetext{
${ }^{7}$ Essa pesquisa foi aprovada pelo Comitê de Ética em Pesquisa da Universidade de Brasília, sob o número CAAE 41857114.1.0000.0030.
} 
conhecer a perspectiva das próprias pessoas sobre as questões apresentadas. Nesse caso, as etnografias tendem a refletir uma tomada antropológica na pesquisa.

A avaliação da corporeidade expressa pela dança coloca-nos perante uma encruzilhada fundamental: primeiramente, essa relação não é tão evidente nem mesmo pelos próprios agentes (no caso, os jovens do MRCC). Em segundo lugar, não sendo antropóloga, então deveria ser possível, pelo menos, colocar a hipótese de que a teoria (em etnografia) poderia ser falsa a meu respeito. Mas a consideração dessa última possibilidade parece, por seu turno, conduzir-nos à seguinte alternativa desejável: há um claro movimento de aproximação e distanciamento do estudo etnográfico, como também faz decidir por um estudo de campo que se inspira na etnografia.

A despeito dessa dificuldade, Gil (1999) parece ter favorecido a opção por algo como esse caminho. Com efeito, ele considera que o estudo de campo é a melhor maneira de se inquirir sobre o assunto, pois este tende a utilizar muito mais a observação. Nesta pesquisa busca-se estudar um único - grupo, ressaltando a interação de seus componentes. Assim, o estudo de campo nos permite enveredar por uma pesquisa de orientação etnográfica, alcançando nossos objetivos, sem, todavia, "ferir" alguns pressupostos da etnografia, que, para muitos antropólogos, deve ser vista como um método eminentemente do trabalho deles.

\subsection{Procedimentos para a obtenção de informações}

De modo geral, os procedimentos para a obtenção de informações foram a observação (registrada por diário de campo) e entrevista semipadronizada. Consoante Angrosino (2009, p. 56) a "observação é o ato de perceber as atividades e os inter-relacionamentos das pessoas, no cenário de campo, através dos cinco sentidos do pesquisador". A observação foi realizada no local da pesquisa, com os participantes tendo consciência de que estavam sendo observados. As reuniões do grupo foram acompanhadas durante sete meses e duas semanas, que incluiu a intercessão, a missa de domingo à noite (acolhida), a formação dos servos, o encontro de sábado à noite, a adoração de iniciação dos servos, e o quarto encontro Ágape, o retiro ${ }^{8}$.

Houve a identificação da pesquisadora para a comunidade pesquisada em cinco momentos distintos, durante toda pesquisa, duas no primeiro dia em campo, ao final do retiro, em um vídeo feito

\footnotetext{
${ }^{8}$ Segundo a RENOVAÇÃO CARISMÁTICA CATÓLICA BRASIL (s/d), os retiros são encontros para oração semelhantes aos que ocorrem nos grupos de oração, no entanto eles ocorrem uma vez ao ano e durante um fim de semana visando aprofundar o conhecimento de renovação na fé.
} 
no retiro, que foi passado ao Grupo de oração em um sábado à noite, e em um artigo da revista da Paróquia Sagrada Família (Anexo I) ${ }^{9}$.

No primeiro dia em campo, ainda no mês de julho de 2014, me coloquei diante dos servos, durante a reunião de formação, a fim de explicar a pesquisa, seus objetivos e dirimindo possíveis dúvidas. Nesse dia, ao final do grupo de oração, o mesmo ato foi repetido. No retiro, que aconteceu na última semana do mês de novembro, havia muitos atores sociais de fora e muitos perguntaram o que estava sendo anotado no caderno; também necessário foi a identificação como pesquisadora. Para tanto, ao final foi cedido um espaço onde foi explicada a pesquisa. Ainda me entrevistaram com uma câmera e um microfone, expliquei minha pesquisa e, por ter mais tempo, apresentei algumas ideias. Esta entrevista foi gravada e passada cerca de dois meses depois (do retiro), ao final de uma reunião do grupo de oração.

Durante a inserção em campo, tudo o que foi percebido foi registrado em um diário de campo, tendo-se por base um roteiro preestabelecido (Anexo II) e formulado segundo proposta de Adler e Adler (1998), citado por Flick (2009, p.205), que perpassou pelas seguintes fases: a seleção de um ambiente - ou seja, onde e quando os processos e as pessoas interessantes para a pesquisa podem ser observados; a definição do que deve ser documentado na observação e em cada caso; o treinamento dos observadores a fim de padronizar esses focos; observações descritivas que forneçam uma apresentação inicial e geral do campo; observações focais que se concentrem nos aspectos relevantes à questão de pesquisa; observações seletivas cuja finalidade seja a compreensão intencional dos aspectos centrais; o fim da observação - quando se atinge a saturação teórica, ou seja, quando outras observações não trouxeram nenhum conhecimento adicional.

Essas etapas da observação ${ }^{10}$ em campo foram complementadas pelas entrevistas semipadronizadas, conforme roteiro anexo (Anexo III). De acordo com Flick (2009), na entrevista, as relações formadas servem ao propósito de tornar mais explícito o conhecimento implícito do entrevistado. Com base nessa informação, a intenção, ao utilizar a entrevista, é a de buscar o esclarecimento, caso haja a necessidade, após a realização do procedimento da observação, bem como confirmar ou confrontar algum fato.

Os documentos também seriam utilizados como fonte de informações. Buscou-se encontrar fotos, vídeos, ou qualquer outro documento que pudesse estar relacionado às atividades desenvolvidas pelo grupo Ágape. No entanto, apesar de comentarem sobre esse material (diversas

\footnotetext{
${ }^{9}$ Quando meu trabalho de campo já estava quase finalizado, um artigo que havia sido encaminhado para a revista da Paróquia Sagrada Família no primeiro mês de pesquisa, foi publicado e distribuído a todos os frequentadores do local (SILVA, 2015).

${ }^{10}$ É válido mencionar que a fim de facilitar o processo de observação, tentou-se utilizar de filmagens. No entanto, percebeu-se que a presença da câmera causava constrangimento aos pesquisados e, além disso, poucos participantes se manifestaram favoravelmente em autorizar o uso de suas imagens para fins de pesquisa. Desse modo, desistiu-se do uso dessa técnica.
} 
fotos, vídeos e um documento de fundação do Grupo de Oração Ágape), tais documentos não foram fornecidos para a pesquisa.

\subsection{Lócus e sujeitos da pesquisa}

A Paróquia Sagrada Família na Vila Canaã está vinculada à Arquidiocese de Goiânia/Goiás, região Centro-Oeste do Brasil. Está situada em um bairro de classe média baixa daquela cidade, por casas simples, não possui edifícios, apresenta pouca atividade comercial, tendo-se como exceção uma "feira de produtos sem procedência para carros". A paróquia se encontra em uma praça, que está localizada na parte sudoeste da mesma, na rua professor Lázaro Costa com a rua C quatorze. Com efeito, é precisamente nesse espaço que o grupo Ágape desenvolve suas atividades, utilizando vários locais dentro da paróquia, como a própria igreja, o espaço da catequese e o auditório para realizar suas reuniões.

Pode ser observada, na imagem abaixo, que a Igreja da paróquia Sagrada Família (em amarelo) se encontra posicionada à direita de suas dependências. À esquerda da Igreja (em laranja, marrom e vermelho ${ }^{11}$ estão os espaços utilizados pelo grupo Ágape para suas atividades. Entre a igreja e suas dependências, existem tendas que, embora sejam instalações provisórias, se encontram naquele local permanentemente.

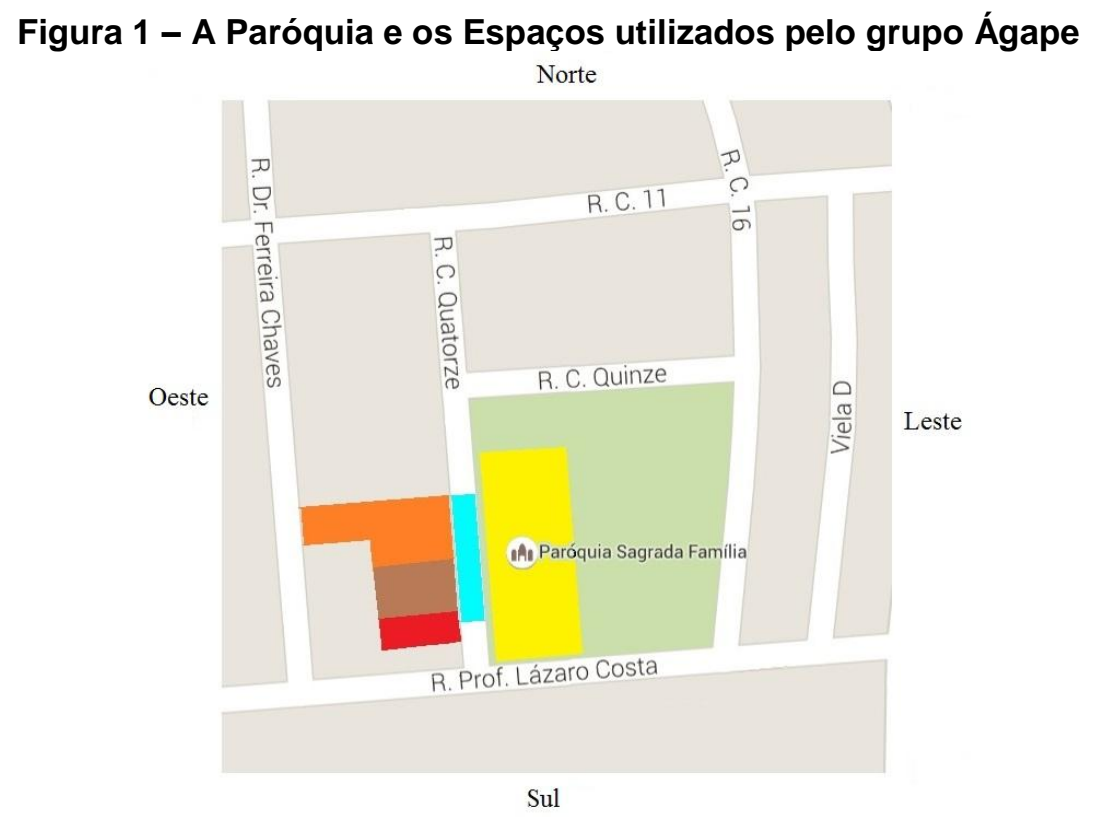

Fonte: Adaptado do google mapas pela Autora (2015).

\footnotetext{
${ }^{11}$ A dependência de cor laranja se refere ao espaço da catequese (uma parte é de três andares), a de marrom é destinada às atividades sociais e a de vermelho possui dois andares, no andar de cima se encontra o auditório, onde são realizadas as reuniões de sábado à noite do Ágape.
} 
O que caracteriza o Grupo de Oração Ágape são as reuniões oferecidas à comunidade, em geral, jovens que almejam o matrimônio. Tais reuniões têm a peculiaridade de contar com a participação de jovens, para que sejam formados relativamente à afetividade e sexualidade. As reuniões duram cerca de duas horas, das $19 \mathrm{~h}$ às $21 \mathrm{~h}$ e são compreendidas em cinco partes: terço, animação, oração, pregação, avisos e consagração. Tais atividades acontecem durante todos os sábados do ano, com algumas exceções, no auditório da Paróquia Sagrada Família, em Goiânia, na Vila Canaã. Para que as reuniões aconteçam, são necessários dois grupos distintos de pessoas: os servos - membros do grupo que se dedicam às atividades de organização e execução - e os demais participantes - pessoas da comunidade que frequentam os encontros. No grupo Ágape, a comunidade se constitui por cerca de quarenta jovens, que tem em comum o fato de aspirarem à condição de casados, encontrando-se numa faixa etária entre vinte a trinta anos, com poucas exceções.

Foram realizadas entrevistas que atendiam a um mesmo roteiro, com dois tipos de grupos. O grupo 1 foi constituído pelos coordenadores do Ágape, o grupo 2 o dos participantes da comunidade. As tabelas 1 e 2 apresentadas compreendem os nomes fictícios ${ }^{12}$, o mês de realização das entrevistas, o sexo, a função/vínculo, no caso dos coordenadores do grupo, o local da entrevista e a duração aproximada em minutos.

Tabela 1 - Grupo 1 (Entrevistas com os Coordenadores)

\begin{tabular}{|c|c|c|c|c|c|c|}
\hline Entrevistado & Identificação & Mês/Ano & Sexo & Função/vínculo & Local & Duração \\
\hline Paulo & EP & $\begin{array}{l}\text { Fev } \\
2015\end{array}$ & M & $\begin{array}{l}\text { Coordenador do } \\
\text { grupo de oração }\end{array}$ & $\begin{array}{l}\text { Sala de } \\
\text { Catequese da } \\
\text { Paróquia }\end{array}$ & 40 \\
\hline Bárbara & EB & $\begin{array}{l}\text { Nov } \\
2015\end{array}$ & $F$ & $\begin{array}{l}\text { Coordenadora do } \\
\text { ministério de musica }\end{array}$ & $\begin{array}{c}\text { Sala da } \\
\text { Paróquia } \\
\text { Provisória para } \\
\text { Ensaios do } \\
\text { Ágape }\end{array}$ & 25 \\
\hline Mateus & EM & $\begin{array}{l}\text { Fev } \\
2015\end{array}$ & M & $\begin{array}{l}\text { Coordenador do } \\
\text { ministério de acolhida }\end{array}$ & $\begin{array}{l}\text { Sala de } \\
\text { Catequese da } \\
\text { Paróquia }\end{array}$ & 20 \\
\hline
\end{tabular}

Fonte: Autoria própria (2015)

Em relação à entrevista com os coordenadores (Tabela 1 - acima), as entrevistas foram realizadas com o coordenador do ministério de música e da acolhida, não tendo sido possível

\footnotetext{
${ }^{12}$ Todos os nomes aqui citados serão fictícios, atendendo-se ao que se propôs como critério junto ao Comitê de Ética em Pesquisa.
} 
entrevistar a coordenadora do ministério da intercessão ${ }^{13}$. O grupo 2, constituído pelos participantes da comunidade, foi selecionado à medida que os participantes atendiam aos seguintes critérios: (a) a participação e (b) o nível de envolvimento no grupo, sendo a metade deles do sexo feminino e a outra metade do sexo masculino.

Tabela 2 - Grupo 2 (Entrevistas com os participantes da comunidade)

\begin{tabular}{|c|c|c|c|c|c|}
\hline Entrevistado* & Identificação & Mês/Ano & Sexo & Local & Duração \\
\hline Pablo & E1 & $\begin{array}{l}\text { Nov } \\
2014\end{array}$ & M & $\begin{array}{l}\text { Sala da Paróquia } \\
\text { Provisória para } \\
\text { Ensaios do Ágape }\end{array}$ & 25 \\
\hline Gustavo & E2 & $\begin{array}{l}\text { Nov } \\
2014\end{array}$ & M & Chácara da Paróquia & 35 \\
\hline Eduardo & E3 & $\begin{array}{c}\text { Dez } \\
2014\end{array}$ & M & $\begin{array}{l}\text { Sala de Catequese } \\
\text { de outra Paróquia }\end{array}$ & 20 \\
\hline Lúcio & E4 & $\begin{array}{c}\text { Jan } \\
2015\end{array}$ & M & $\begin{array}{c}\text { Sala de Catequese } \\
\text { da Paróquia }\end{array}$ & 25 \\
\hline Gabriel & E5 & $\begin{array}{l}\text { Fev } \\
2015\end{array}$ & M & Capela da Paróquia & 40 \\
\hline Isadora & E6 & $\begin{array}{l}\text { Nov } \\
2014\end{array}$ & $F$ & $\begin{array}{l}\text { Sala da Paróquia } \\
\text { Provisória para } \\
\text { Ensaios do Ágape }\end{array}$ & 20 \\
\hline Gabriela & E7 & $\begin{array}{c}\text { Dez } \\
2014\end{array}$ & $\mathrm{~F}$ & $\begin{array}{l}\text { Sala de Catequese } \\
\text { de outra Paróquia }\end{array}$ & 60 \\
\hline Carina & E8 & $\begin{array}{c}\text { Jan } \\
2015\end{array}$ & $\mathrm{~F}$ & $\begin{array}{l}\text { Hall de entrada do } \\
\text { condomínio da } \\
\text { entrevistada }\end{array}$ & 30 \\
\hline Aline & E9 & $\begin{array}{l}\text { Fev } \\
2015\end{array}$ & $\mathrm{~F}$ & $\begin{array}{l}\text { Sala de Catequese } \\
\text { da Paróquia }\end{array}$ & 25 \\
\hline Taís & E10 & $\begin{array}{l}\mathrm{Fev} \\
2015\end{array}$ & $\mathrm{~F}$ & $\begin{array}{l}\text { Sala de Catequese } \\
\text { da Paróquia }\end{array}$ & 15 \\
\hline
\end{tabular}

Fonte: Autoria própria (2015)

Em relação a esse grupo (Tabela 2 acima), obteve-se o número total de dez entrevistas. O critério de definição do número ocorreu por saturação, isto é, quando as respostas começaram a se tornar retóricas com ambos os sexos, interrompeu-se o processo de entrevistas.

13 Apesar de oito tentativas, somente não foi possível a entrevista com a coordenação do ministério da intercessão. 


\subsection{Procedimentos de interpretação de informações}

Após as informações obtidas durante o trabalho de campo realizou-se a interpretação. Os procedimentos de análise partiram dos registros do diário de campo e das transcrições das entrevistas. Todas as informações obtidas, após transcritas e digitalizadas, foram submetidas à averiguação, por meio de uma leitura geral. Posteriormente, as informações foram articuladas entre si e com as contribuições teóricas.

Para Gibbs (2009), uma das questões mais importantes da etapa de interpretação das informações da pesquisa qualitativa é garantir que ela seja o mais analítico e teórica possível. Portanto, deve-se afastar-se de classificações que sejam assentadas no senso comum, preferindo novas formas teóricas e analíticas de explicação. Seguindo essa compreensão, a interpretação das informações está compreendida em três etapas, a saber: classificação e organização dos achados da pesquisa; estabelecimento de relações entre essas informações e os conceitos por ela suscitados ${ }^{14}$, e, por fim, o tratamento qualitativo dos dados.

Desse modo, no capítulo que se segue, intitulado "Sendo Ágape", será iniciado o processo de interpretação das informações, em que situa o grupo Ágape no contexto do Movimento de Renovação Carismática Católica.

\footnotetext{
${ }^{14}$ Considerando-se, obviamente, o quadro teórico aqui adotado.
} 


\section{CAPÍTULO II - SENDO ÁGAPE: O COTIDIANO DE ECOS DE VOZES DESTOANTES EM SINTONIA}

Neste capítulo aborda-se a origem, trajetória e o cotidiano do Grupo de Oração Ágape (grupo Ágape) do Movimento de Renovação Carismática Católica, apresentando-se a descrição de suas atividades. Como um grupo de oração, o Ágape pertencente à MRCC define seus grupos: "grupo de oração é a base da estrutura da Renovação Carismática" (Doc. 1, anexo IV), sendo formado por um número variado de pessoas, que se reúnem semanalmente nas paróquias e são liderados por leigos ${ }^{15}$.

Essa definição de grupo de oração, apresentada pela RCC, aproxima-se da noção de grupo presente na discussão sociológica. De acordo com Lakatos e Marconi (1999), o homem, por ser um ser social, se organiza em grupos, porém, sua criação e manutenção levantam o problema do recrutamento de membros, que ocorre de diferentes maneiras. A participação dos indivíduos em grupos se dá por meio de: (a) aceitação voluntária da participação; (b) indicação, nomeação ou designação e (c) eleição. No entanto, todo grupo possui características em comum, podendo-se definir como social todo aquele formado por indivíduos que desempenham papeis, seguindo normas, que comungam de valores e interesses sociais, visando a um objetivo comum e determinado (LAKATOS e MARCONI, 1999). Assim, se um grupo se reúne à medida que todos os participantes compartilham de um objetivo comum, no caso específico dos grupos de oração da RCC, a finalidade maior é a oração como forma de aproximação com o Deus do catolicismo romano, por intercessão do Espírito Santo, já que se trata de um grupo voltado ao pentecostalismo.

O catolicismo romano é a maior, em número de fiéis, e mais antiga Igreja do mundo e a RCC surge possuindo seu reconhecimento e seu papel destacado na Igreja. Maués (2007), pesquisador do assunto, destaca que foi somente com o Concílio Vaticano II $^{16}$ que a RCC foi oficializada pelo catolicismo romano, o que contribuiu para a valorização de algumas práticas religiosas anteriormente esquecidas pelo catolicismo, como os rituais da dança.

Por seu turno, Sofiati (2009), que realizou uma pesquisa histórica sobre a origem da RCC, registra que suas bases fundantes encontram-se na Universidade de Duquesne, em Petersburgo.

${ }^{15}$ De acordo com o CATECISMO DA IGREJA CATÓLICA (2003), os leigos são cristãos batizados que não fazem parte de qualquer estado religioso reconhecido pela Igreja, ex: não são padres, freiras, ou diáconos.

${ }^{16}$ O Concílio Vaticano II ocorreu na década de 60 do século XX, seus documentos disponíveis na internet datam de 4 de dezembro de 1963 a 7 de dezembro de 1965, sendo todos eles assinados pelo Papa Paulo VI. Disponível em: http://www.vatican.va/archive/hist_councils/ii_vatican_council/index_po.htm. Acesso em: 29 de junho de 2015. 
Desse modo, para a autora, foi dentro de tal universidade, em uma reunião de estudantes e professores, que o movimento se iniciou.

A busca pela cura intermediada pelo Espírito Santo, almejada por parte de membros da Renovação Carismática Católica foi objeto de reflexão e pesquisa de Thomas Csordas (2008), em seu livro intitulado Corpo/significado/cura. Csordas (2008) afirma que a Renovação Carismática Católica se introduziu em denominações cristãs como a católica romana, levando para dentro delas um complexo de práticas. O movimento é chamado de Renovação Carismática Católica pelo uso ritual dos carismas ou dons do Espírito Santo, entendidos como modos para a expressão do poder espiritual. Historicamente, segundo esse autor, o movimento originou-se no período pós-Segunda Guerra Mundial. Ele acelerou e adquiriu adeptos mais jovens durante a comoção social dos anos 1960. Atingiu seu apogeu de fervor e apelo popular nos anos de 1970. Acomodou-se num nicho socialmente conservador, mas teologicamente entusiástico, nos anos 1980.

No Brasil, esse movimento chegou em 1969 com o padre Harold Joseph Rahm, que nasceu no Texas (Estados Unidos da América), e com Edward John Dougherty nascido em Lousiana (EUA). No final dos anos de 1970, já havia uma presença significativa, suscitando no interior da Igreja reações que pendiam entre a rejeição e o apoio. Ao longo dos anos de 1980, a RCC se consolida e se espalha pelo território nacional. Na década de 1990, ela tem sua estrutura organizativa figurada pelos padres cantores, que foram o principal meio de adesão dos fiéis. No entanto, ela só se consolida nos anos 2000, quando passa a ter nas comunidades de vida e aliança, o seu principal meio de recrutamento (CARRANZA, 1998).

No escopo dessas discussões e de disputas no seio da Igreja Católica brasileira, os grupos de oração, principalmente aqueles voltados à $\mathrm{RCC}$, adquirem papel de grande relevância para a manutenção dos postulados do catolicismo na base, isto é, junto à comunidade de fiéis. Com o mesmo objetivo dos demais grupos de oração, o Ágape surge em Goiânia/GO, em junho de 2011 (cf. $E P)$.

A origem desse grupo esteve, no entanto, atrelada à extinção de outro grupo - Juventude na Luz - que desenvolvia atividades na Paróquia Sagrada Família. O Juventude na Luz tornou-se posteriormente o grupo Aliança, mas com a transferência do pároco da Paróquia Sagrada Família para a Paróquia de Aparecida de Goiânia, o grupo foi extinto, surgindo em seu lugar o grupo Ágape (cf. EB). A primeira formação do Ágape apresentava apenas três pessoas, que se tornaram coordenador e servos. Atualmente, o grupo é formado por vinte integrantes, sendo que destes quatro são coordenadores e dezesseis são servos (cf. EP e EB). 


\subsection{0 cotidiano em um grupo de oração}

No quadro da Sociologia, a vida cotidiana não é apenas uma realidade dada, mas construída. Trata-se de um mundo que se constitui por meio do pensamento e da ação de homens comuns, sendo afirmado como real por eles. Em suas explicações sobre o sentido da vida cotidiana, Berger e Luckman (2011) apresentam um conjunto de elementos que ajudam a matizar o sentido sociológico daquilo que comumente chamamos de rotina, rotineiro ou atividades do dia-a-dia. Nesse âmbito, os autores elencam sete aspectos da vida cotidiana, a saber: a consciência, a linguagem, o "aqui e agora", o mundo intersubjetivo, o "aí" realidade, os setores e a estruturação (temporal e espacial).

Berger e Luckman (2011), primeiramente, afirmam que os indivíduos, em seus processos de interação social, experimentam a vida cotidiana num estado de total vigília, conscientes, apreendendo a realidade de sua vida diária. Em segundo lugar, tal realidade apresenta-se de forma ordenada, e a linguagem proporciona os elementos necessários para determinar a ordem e o significado na vida cotidiana. Em terceiro, o cotidiano se constitui em torno do "aqui" do corpo e do "agora" do presente, no entanto, ele não se esgota no presente imediato, mas abraça os fenômenos que estão evidentes no "aqui e agora". Em quarta instância, encontra-se o mundo intersubjetivo, que é aquele em que o indivíduo compartilha com outros seus esquemas de valores e pensamentos.

O "aí" realidade, mencionada em quinto lugar, significa que a vida cotidiana não requer maior verificação que se estenda além de sua simples presença. Por conseguinte, em sexta posição, está a realidade do cotidiano, que se divide em setores que são apreendidos rotineiramente e outros, que se apresentam a mim, com problemas de espécies semelhantes aos da rotina. Por último, o mundo da vida cotidiana, que requer seu espaço e tem seu próprio padrão de tempo, que é acessível à intersubjetivamente. A estrutura temporal da vida cotidiana não somente impõe sequências predeterminantes ao indivíduo em um único dia, mas impõe-se também à biografia desse agente em totalidade. Em uma noção geral, a vida cotidiana se apresenta como uma realidade interpretada pelos homens e subjetivamente dotada de sentido para eles, na medida que formam um mundo coerente.

Apropriando-se dessa noção de cotidiano de Berger e Luckmann (2011), entende-se que o Ágape realiza uma série de atividades que corroboram para a formação de outra dimensão da realidade ordinária. Do calendário semanal das atividades do grupo, observei a formação dos servos, a intercessão, a participação nas missas de domingo à noite, e os encontros de sábado à noite. Com referência ao calendário anual, foram observados o IV Encontro Ágape e a adoração de iniciação dos servos. 


\subsection{O encontro dos servos: a formação de elos entre ecos de vozes destoantes}

"Servo" é o termo utilizado pelo catolicismo para designar todos aqueles que se dedicam ao trabalho dentro da Igreja. Servos são vistos como pessoas bem-aventuradas, que servem aos propósitos da Igreja Católica Romana, atendendo aos anseios do Senhor Jesus Cristo, dedicando-se cotidianamente.

Os servos ${ }^{17}$ de uma maneira geral e, especificamente aqueles do grupo Ágape, desempenham um papel mais ativo dentro da comunidade de fiéis, pois realizam atividades de organização e execução das atividades fornecidas aos participantes

Dividem-se por ministérios em pequenos grupos de cinco a oito integrantes. Esses ministérios são de música, acolhida e intercessão. De acordo com a Confederação Nacional dos Bispos no Brasil (CNBB), o termo servo tem uma relação direta com o verbo servir.

"Eu vim para servir" é também a carteira de identidade e da missão do cristão. Ser cristão é ser servo e servidor como Jesus foi (Mc 10,45). Ser servo e servidor é ser o prior, ou seja, o primeiro no amor, na caridade e no serviço aos outros como fez também Jesus (Mc 10,44). De fato, o cristão é a imagem e semelhança de Jesus. Este seu viver para servir serve de base para todos os relacionamentos humanos. Serve, sobretudo, para quem ocupa liderança na Igreja e na sociedade. Palavras do papa Francisco aos novos cardeais: "que o povo de Deus veja sempre em nós a firme denúncia da injustiça e o serviço alegre da verdade" (GUIMARÃES, 2015, n.p.).

O termo servo, relativamente ao documento supracitado, associa à condição do cristão a necessidade de servir a Deus. Assim, um bom cristão é o servo que oferece a Deus seus serviços com amor, caridade, alegria, com o intuito de denunciar a injustiça, seguindo os passos de Jesus como uma verdadeira missão.

Com efeito, se a condição de servidão exige desses integrantes a total dedicação às atividades da Igreja, cumprindo os ministérios, a comunidade, por seu turno, que participa das atividades ofertadas pelos servos, tem um papel mais passivo no processo.

O primeiro contato que tive com o Ágape aconteceu na véspera da reunião de servos propriamente dita e que contém elementos importantes da interação social. Descreverei e tentarei interpretar, além da formação de servos como um ritual que se constitui como parte do MRCC, que contém a maior quantidade de elementos da renovação.

O ritual carismático ocorre de diversas formas. Csordas (2008) aponta cinco formas distintas. Há os grandes serviços que surgiram antes da década de 1970, em encontros periódicos, nos quais os participantes do movimento se reúnem nacional ou regionalmente para mostrar sua

\footnotetext{
${ }^{17}$ Durante a pesquisa, a quantidade de servos variou consideravelmente. No início, havia cerca de trinta e ao final da pesquisa participavam ativamente apenas vinte.
} 
força e unidade e, também para cultuar e ensinar. Há ainda os encontros (ou grupos) de oração, que são semanais e menores. Os encontros mais intensivos são realizados nos retiros de um dia ou de final de semana, que também são chamados de dias de renovação. Há também sessões particulares organizadas com um ministro ou com uma equipe, aconselhamentos pastorais e por telefone. Finalmente, existe a devoção privada. No entanto, é através dos encontros/grupos de oração que a maioria dos católicos carismáticos adere ao movimento (CSORDAS, 2008).

Antes de iniciar minha entrada em campo, conversei com a coordenação do grupo, bem como com o pároco local, a fim de solicitar autorização para a realização da pesquisa. A entrada em campo ocorreu em julho de 2014, desse modo como eu havia conversado previamente com o coordenador do grupo, conhecimento tinha de que a reunião de servos se iniciava todos os sábados no final da tarde, às $17 \mathrm{~h}$.

Cheguei ao local pontualmente, então procurei por alguém do Ágape. Logo avistei Sandra e João, dois servos do ministério de intercessão. Eles encontravam-se no hall de entrada da catequese. Cumprimentei-os, ajudei-os a se lembrarem de que eu era pesquisadora e que estaria ali para dar início ao meu trabalho de campo. Os demais servos iam chegando e se aglutinaram ao nosso redor. Todos me cumprimentaram com a mesma alegria que cumprimentavam os demais. Mesmo aqueles que eu tenho certeza que não me conheciam, sempre estavam com um sorriso no rosto. Cordialmente, apertavam a minha mão ou davam um abraço.

Conforme Maués (2007), o toque corporal - como o aperto de mão ou o abraço - é comum entre os carismáticos quando as pessoas se encontram pela primeira vez. Eu diria também que o toque corporal é um dos elementos essenciais na interação social entre os jovens carismáticos do Ágape, o que o torna essencial é o fato de acontecer nos primeiros momentos de interação, assemelhando-se a um gesto cordial e de acolhida.

Assim que os líderes chegaram, nos dirigimos ao auditório da paróquia Sagrada Família e foi iniciada a reunião. Entramos no Auditório. Surpreendeu-me a beleza do local. Todo decorado e com bons equipamentos de som. A única identificação daquele espaço como religioso, dava-se em razão do altar e da presença de diversas imagens religiosas. A disposição das pessoas ali dentro podia ocorrer de maneira flexível, pois as cadeiras eram de plástico e não eram fixas.

Ao entrarem no auditório, os servos imediatamente pegavam uma das cadeiras, na pilha ao fundo do auditório, para sentar e formava-se um círculo bem próximo ao altar, mesmo procedimento que segui.

Como um ritual, o acolhimento, revestiu-se de um conjunto de ritos, iniciando-se por uma rápida lembrança de todos os que participam do grupo, uma espécie de lista de frequência, questionando-se se estariam presentes ou se informaram da ausência. Logo após, Paulo, o 
coordenador do grupo, iniciou a oração agradecendo e voltando seu olhar para o chão, o que foi imediatamente seguido por todos os presentes. Paulo diz: "Senhor, queremos louvar e agradecer por esse sábado...". Todos fecharam os olhos e começaram a falar junto com ele, formando ecos de distintas vozes, apesar de que a voz de Paulo sobressaiu perante as demais.

Com referência aos ecos de distintas vozes, observou-se que eram marcados por orações realizadas pelos demais membros, que se remetiam a pedidos de intercessão e falas de agradecimentos, relacionadas a eles próprios, ou às pessoas do seu círculo familiar, ou de amizade, posto que ressaltavam em suas orações nomes de pessoas, que eram provavelmente conhecidas.

Desse modo, o ritual de acolhimento configurou-se por orações orientadas em que se sobressaia a voz da liderança do grupo - Paulo - e, orações pessoais dos demais membros, que se constituíam por ecos de distintas vozes. Maués (2007) observa em seus estudos sobre a RCC que orar em voz alta é também uma técnica corporal, à medida que é uma ação que constitui uma forma de o corpo se expressar, através da emissão de sons, de modo compreensível ou não. Sempre há orações no ritual cotidiano na vida de um católico carismático. As orações devem ser, sobretudo, de louvor, sendo permitido que se solicite graças aos santos, à Maria e à divindade. Porém, em seus achados de pesquisa, o autor mencionado registra que: “(...) critica-se aqueles que somente pedem graças pessoais: deve-se pedir antes pelos outros, mas, principalmente, deve-se louvar a Deus" (MAUÉS, 2007, p. 131).

Mas há outro aspecto das técnicas corporais descritas por Maués (2007) em seu estudo, que também se evidenciou no Ágape. Trata-se da "fala egocêntrica", que pode ser definida como um momento de oração, em que cada um faz suas próprias orações empregando palavras diferentes. Forma-se assim uma balbúrdia de vozes, em que se ouve sobretudo a fala do líder. No caso específico do ritual de acolhimento do Ágape, essas técnicas corporais foram produzidas pelas vozes ecoantes dos demais membros, com orações pessoais e para pessoas de seus círculos familiar ou de amizade. Percebe-se a importância da acolhida, por meio da oração de louvor, como primeira oração conjunta dos servos do Ágape naquele dia.

O louvor cessou e cedeu lugar ao silêncio. Pude notar que havia o som de um violão dedilhado ao fundo. Paulo deu continuidade incentivando para que pedíssemos a intercessão do Espírito Santo para aqueles - demais membros do grupo - que não estavam presentes. Novamente gerou-se, por meio dessa oração, os ecos de vozes destoantes, denominados por Maués (2007) de "balbúrdio de vozes", formado pelas falas egocêntricas.

Ao cessar das falas egocêntricas, Lucas (servo do ministério de música), que estava com o violão em mãos, iniciou uma canção que tinha como tema a súplica pelo Espírito Santo. Com o 
decorrer da canção, as pessoas vão esboçando gestos corporais variados, que serão aqui descritos e comentados $^{18}$.

Espírito enche a minha vida (muitos levantam a cabeça e alguns começam a trocar o peso do corpo de uma perna a outra, fazendo movimentos pendulares, de um lado para o outro, como se estivessem sido embalados pela canção). Enche-me com teu poder, pois de ti eu quero ser, Espírito enche o meu ser (nota-se que os que começaram a ser embalados pela canção puxaram os que estavam ao seu lado). Espírito enche a minha vida. Enche-me com teu poder, pois de ti eu quero ser, Espírito enche o meu ser (nesse ponto da canção, todos estavam balançando de um lado para o outro). As minhas mãos eu quero levantar, e em louvor te adorar (as pessoas levantaram as mãos, alguns no início da frase já estavam de mãos para cima, outros só levantaram no final, mas todos levantaram as mãos, mais ou menos, na altura de seus ombros). Meu coração eu quero derramar, diante do teu altar (alguns contraíram músculos da face). As minhas mãos eu quero levantar, e em louvor te adorar. Meu coração eu quero derramar, diante do teu altar (o pêndulo lateral de todos durou até o fim da canção).

Paulo recomendou a todos que colocassem as mãos no coração e fizessem uma oração de súplica, um pedido para si mesmo. Todos soltaram as mãos e acataram a sua recomendação. $O$ toque do violão continuava forte, muitas pessoas continuavam a se embalar. Novamente a súplica produz os ecos de vozes destoantes, o balbúrdio, que continuava quando o estilo da oração era trocado, rapidamente, a súplica dá lugar à oração em línguas. Paulo foi o primeiro a orar em línguas.

A oração em línguas, ou a glossolalia, de acordo com Csordas (2008), é também um elemento de empoderamento, ou seja, uma manifestação de poder do indivíduo perante os outros, à medida que para os demais, ele se apresenta como um escolhido por Deus para proferir suas palavras. Csordas (2008) estabelece que,

A glossolalia é um importante símbolo multivocal. Ela é em primeiro lugar,
um dom espiritual e, portanto, uma manifestação direta do poder místico
com uma linguagem de inspiração divina, que capacita o orador a louvar a
Deus, com um poder inexistente numa língua que é meramente uma
criatividade da competência humana. Em segundo lugar, no nível do próprio
discurso, a sua força retórica provém de sua "falta de sentido", ela quebra
os cânones de inteligibilidade naturalizados no discurso cotidiano, criando
assim a possibilidade para novos tipos de significado (CSORDAS, 2008,
p.64).

A recomendação de Paulo, de pôr as mãos no coração para fazer súplicas, faz com que ocorra uma variação na técnica corporal habitual utilizada pelos servos a fim de realizar orações no momento de sua formação, que é ficar de mãos dadas. Tal ato pode ser definido como um gesto

\footnotetext{
${ }^{18}$ Por uma questão de organização de escrita, os gestos serão colocados entre parênteses, após o período da música ao qual se referem.
} 
comum entre eles, pois sem ninguém dizer nada, eles já deram as mãos para iniciar a oração. Pôr as mãos no coração aparenta ser uma variação, pois eles só fazem esse gesto após a indicação de Paulo. Os carismáticos, em geral, possuem gestos corporais variados para realizar orações, segundo Maués (2007), e fundamentalmente percebe-se no Ágape que alguns gestos podem ser mais utilizados em certas situações do que em outras.

Durante a oração em línguas, observou-se uma gama de técnicas corporais, que de alguma forma refletem a ação do poder de Deus. Os que não se embalam pelo ritmo da canção, manifestam alguma outra técnica corporal repetitiva, como agitar a mão que não se encontra sobre o coração. Havia uma moça, Amanda (serva da intercessão), que estava com sua mão direita no coração, e com seu cotovelo esquerdo flexionado junto à cintura, ela não estava embalada, mas movia sua mão (que estava com a palma voltada para cima) para cima e para baixo, em movimentos rápidos e intermitentes. O curioso é que parece que para orar em línguas, não é necessário só movimentar a boca para produzir algum som, mas tem que fazer algo a mais com o corpo, por exemplo, embalar-se ao som da música, contrair algum músculo da face, ou utilizar técnicas corporais repetitivas, como a de Amanda.

Quando os ecos de vozes destoantes cessaram e as técnicas corporais se tornaram menos intensas, Paulo orientou as pessoas para que se entregassem a Deus. As pessoas começaram a falar, faziam seus pedidos; mas a voz de Paulo ficou, naquele momento, claramente destacada das demais. Chamou-me à atenção o fato de Sandra, uma das coordenadoras do grupo, que estava com a face contraída a maior parte do tempo, emitir uma voz de choro nesse momento, e ela começou a orar em línguas e sua oração parecia muito com o choro de uma criança.

Todos voltaram a orar em línguas, porém dessa vez, percebe-se que os gestos eram mais contidos, com a face branda, mexendo apenas os lábios. Mas a maioria ainda seguia o padrão de expressar algum gesto corporal, junto com a oração em línguas. Em seguida, cantou-se novamente, a oração pela intercessão do Espírito Santo, retomando-se gestos, embalados pela canção.

Ao cessar da canção, Sandra disse que quando rezávamos, Deus colocava no coração dela que há muitos corações doloridos. Ela disse, ainda, que percebeu que não estávamos sozinhos, e incentivou que fizéssemos a imposição de mãos, colocássemos as mãos uns nos ombros dos outros e intercedêssemos pelo irmão. Ao colocar a mão na pessoa da direita, o círculo se fechou um pouco. Em breve formou-se um novo eco de vozes destoantes, dessa vez com a voz de Sandra se sobressaindo e o violão sempre ao fundo.

Notou-se que de todos os presentes, cinco se embalavam de um lado para o outro, para realizar a oração e outros ainda faziam careta, gerada pela contração de músculos da face. Quando alguém começava a orar em línguas, todos sempre acompanhavam, dessa vez não foi diferente, alguém começou com a glossolalia e brevemente todos realizavam o mesmo tipo de oração. 
Voltou-se à mesma canção. Espírito enche a minha vida. Enche-me - a voz de Sandra se sobressaiu dizendo "nos", no lugar do "me" - com teu poder. Sandra anunciou "pois de ti queremos ser" e todos assim cantavam, Espírito enche o meu ser. Sandra anunciou, "Espírito enche a nossa vida" todos cantaram: "Espírito enche a nossa vida". Enche-nos com teu poder, pois de ti queremos ser, Espírito enche o nosso ser. Sandra presidiu dizendo "agarra a mão do seu irmão e levanta o mais alto". Todos deram as mãos e as levantaram acima da cabeça e continuaram cantando. As nossas mãos queremos levantar, e em louvor te adorar. Nosso coração queremos derramar, diante do teu altar.

Observou-se que quando estavam ainda sem dar as mãos, poucas pessoas estavam embaladas pela música. Ao dar as mãos, as pessoas que não estavam embaladas, começaram a se movimentar de um lado para o outro. Até o final da música, todos estavam fazendo o movimento de um lado para o outro, praticamente com a mesma amplitude. Nesse caso, pode-se dizer que se trata de uma forma de comoção social, como uma espécie de efeito dominó, pois à medida que vai se formando o elo, uns dando as mãos aos outros, todos vão sendo paulatinamente envolvidos pelo "espírito" de interação grupal, configurando uma corrente de oração.

Paulo retomou a palavra e procurou fazer uma reflexão a partir da letra da música, dizendo em resumo que o lugar de nosso coração era diante de Jesus, diante do altar. Enquanto ele falava, havia o violão dedilhado ao fundo, e alguns oravam em línguas. Ao fim do momento de reflexão, ele pediu para entregar o coração, a vida, a história para Deus. Houve um momento curto dessa oração, pois ela mal se iniciara e já havia alguém orando em línguas. E, como já dito, quando alguém começava a orar em línguas, os outros acompanhavam.

Paulo encaminhou outro momento de oração, dizendo que quem precisasse de oração, se ajoelhasse e pedisse ao Senhor que viesse sobre você. Disse também que todos iriam clamar sobre você.

Barbara, Isabela e Júlia (serva do ministério da acolhida) se ajoelharam. As pessoas em volta iniciaram a técnica da imposição de mãos, colocando as mãos no ombro ou na cabeça de cada uma delas e, quando isso não era possível, por conta da limitação espacial, sobre o ombro da pessoa que tivesse o contato direto com a pessoa ajoelhada. Alguns rezavam com as suas palavras e outros em línguas. Muitos faziam caretas, e mais da metade estavam embalados pelo som da música.

O fato de impor as mãos, para Maués (2007), é técnica corporal de relevo entre os carismáticos, e para Csordas (2008), é uma retórica de empoderamento. Ou seja, a pessoa que recebe a imposição das mãos se sente mais convencida que o poder de Deus chega não só pela oração que está recebendo, mas principalmente pelo toque que ela recebe. 
Sem mudar de posição, Paulo começou a cantar a música "Incendeia a minha alma"19. A maioria das pessoas continuava rezando enquanto somente ele cantava. Paulo interrompeu a canção e pediu para que todos cantassem, e assim a maioria fez, dando continuidade à música.

Paulo disse para as pessoas tomarem posse da graça de Deus e se levantarem. Em outras palavras, ele pediu para que eles se sentissem persuadidos, se convencessem que receberam a graça de Deus. As pessoas se levantaram e deram as mãos, sem que ninguém nada dissesse. Reafirmando o que foi dito, o dar as mãos é um hábito em uma reunião de servos, se ninguém propuser uma técnica corporal diferente, eles estarão de mãos dadas.

Paulo iniciou uma oração de louvor, começou a agradecer a Deus pela graça derramada, iniciando uma fala retórica com o intuito de gerar a persuasão nos servos. Todos assim o fizeram, agradeceram, formando o eco de vozes destoantes, o balbúrdio.

Novamente todos cantaram, reformulando a canção, transformando-a de um pedido individual para um pedido coletivo. "Incendeia a nossa alma. Incendeia a nossa alma. Incendeia a nossa alma, senhor! Incendeia a nossa alma. Incendeia a nossa alma. Incendeia a nossa alma, senhor!" A maioria das pessoas se embalara.

Sandra convidou Paulo a se ajoelhar e pediu que todos rezassem por ele. Paulo se ajoelhou, todos se aproximaram, impuseram as mãos sobre Paulo, iniciando uma oração orientada por Sandra. No momento em que parecia que as palavras iam se esgotando, (ou as pessoas iam se cansando), alguns servos começavam a orar em línguas, o que dava novo fôlego para a continuação do espírito de comoção gerado pela oração.

A oração em línguas, nesse momento final da reunião, pôde ser interpretada como forma alternativa de mostrar que todos naquele ambiente continuavam em estado de oração. A glossolalia pentecostal é uma forma de elocução caracterizada pela falta de um componente semântico. De forma que se pronuncia sílabas sem sentido. Ainda assim, a glossolalia carrega um significado global como sendo uma forma inspirada de louvar a Deus, mas também pode ser utilizada como uma prece que roga por intervenção ou orientação divina. Contudo, entre os carismáticos, há distintos padrões sintético-fonológicos. Pode haver mais de uma "linguagem de oração" glossolálica, podendo elas ser usadas em diferentes situações e com diferentes intenções (CSORDAS, 2008).

O orar em línguas, de acordo com Maués (2007), muitas das vezes ocorre como uma sequência natural de uma improvisação de orações, para as quais faltam palavras compreensíveis, e as pessoas que possuem o dom passam a orar e - na concepção dos carismáticos - já não são mais elas que oram, mas sim o Espírito Santo através de suas bocas. O dom de línguas apresenta ainda

${ }^{19}$ Incendeia a minha alma, incendeia a minha alma, incendeia a minha alma, Senhor. Espírito santo, vinde orar em mim, Espírito santo, vinde falar em mim. Vinde curar, vinde libertar, nossos corações de toda opressão, vinde transformar, vem incendiar, traz fogo do céu nesse lugar. 
três variações: falar, orar e cantar em línguas. A oração percebida dentro do Ágape foi predominantemente cantada, pude observar apenas pregadores convidados falando ou orando, portanto, entre os servos e os participantes sempre se encontra uma glossolalia cantada.

Dando continuidade, Sandra pediu que todos cantassem "Incendeia a tua alma, vamos cantar". E todos cantaram. Ao cantar, mais pessoas se embalaram, e a amplitude de movimento de alguns aumentou. Paulo sugeriu finalizar o momento de oração com o louvor, formou-se um eco de vozes destoantes, e, logo em seguida, o violão cessou e as vozes também. Rezou-se uma AveMaria. Quando Paulo deu início ao encerramento, alguns membros pediram orações para conhecidos, terminando-se assim o encontro de formação.

Os participantes de grupos de oração, de modo geral, por meio da renovação cotidiana de suas crenças religiosas, são culturalmente influenciados a rezar, em especial em espaços como aquele. A reunião durou mais de uma hora e observou-se que houve durante todo o tempo a participação coletiva, com o envolvimento individual de cada participante. Eles utilizaram-se, provavelmente, de grande parte de seus vocabulários prévios de oração. Ao chegar em determinado ponto, era perfeitamente aceitável que as palavras faltassem, dando ensejo ao fim da reunião de formação dos servos. Porém, quando se imaginava que iria acabar, outro membro dava início a oração em línguas e a reunião prosseguia. Sendo assim, o estado em que se encontravam, transmitiu-me a ideia de que havia algo que estava além da materialidade, fazendo agir. Aqui, podese encontrar dois sentidos para o entendimento da reunião de formação dos servos. O primeiro é o de que os participantes produzem uma linguagem criativa, a fim de afirmar para os outros ou, até mesmo para si, que o momento de oração continua a existir e que pode durar um longo período, ratificando-se que quando um membro do grupo fala em línguas, os demais devem dar continuidade, numa atitude de empoderamento que se estabelece entre eles próprios, conforme enunciou Csordas (2008). Ou ainda, como os participantes preferem afirmar. Trata-se de um momento em que em suas orações e falas não são suas, mas palavras do Espírito Santo, que penetrou em cada um deles fazendo com que tivessem força para continuar a reunião e tornar compreensível (até certo ponto) para os demais, aquilo que receberam por inspiração divina.

Ao orar em línguas, mesmo com um espaço mais restrito, gerado pelo amontoado de pessoas em torno de um único ator social que se encontra ajoelhado, as pessoas se embalavam, portanto se sentiam motivados tanto pelo orar em línguas, quanto pelo som do violão e pela letra da música.

No momento de formação relatado, foram identificadas quatro técnicas corporais incentivadas pela música. São elas: os movimentos pendulares laterais realizados de mãos dadas ou não, levantar as mãos na altura do ombro ou acima da cabeça, também realizados com e sem as mãos dadas, os movimentos rápidos e intermitentes com a mão e contrair músculos da face. É 
interessante notar que os movimentos pendulares se intensificam de mãos dadas, como se a graça fluísse melhor entre os corpos e se manifestasse em cada um deles com a mesma intensidade.

Outras técnicas corporais encontradas na formação foram a imposição de mãos, ficar de joelhos, pôr a mão no peito, dar as mãos, fechar os olhos, e as orações realizadas em voz alta através de falas egocêntricas, gerando sempre o balbúrdio, aqui denominados de ecos de vozes destoantes. Delas, pode-se dizer que as três primeiras foram técnicas mais espontâneas, geradas pelo momento de oração e/ou pela inspiração divina. Realizar orações em voz alta com falas egocêntricas, com os olhos fechados e de mãos dadas, são técnicas feitas com mais frequência que as outras, em suas reuniões de servos.

A interpretação das técnicas corporais utilizadas durante 0 momento de formação possibilita, assim como Csordas (2008), entender, por meio de exemplos extraídos do cotidiano do grupo de oração, mediações para o entendimento de uma clara conexão entre o corpo dos sujeitos e a espiritualidade, fomentada por meio da prática religiosa Católica da Renovação Carismática. A experiência religiosa ensejada contribuiu para o entendimento de que há na constituição do paradigma da corporeidade, uma mescla de vivências e percepções religiosas próprias do catolicismo carismático, que buscam por meio do sentido imagético multisensorial, da glossolalia (oração por línguas), da profecia e do repousar no Espírito, a cura para afastar do corpo os espíritos malignos. A prática religiosa em sua conformação se utiliza do nível pré-objetivo para produzir objetificações novas e sagradas. A prática religiosa explora também o habitus ${ }^{20}$ para transformar as próprias disposições de que é construída, sendo assim, a evocação do nível pré-objetivo e o habitus são elementos fundantes da prática religiosa, atribuindo à mesma um sentido.

Sob o ponto vista do paradigma da corporeidade, originam-se os modos somáticos de atenção, que são compreendidos como as maneiras culturalmente construídas pelas quais damos atenção "a" e "com" os nossos corpos. Csordas (2008) desenvolve a ideia do modo somático de atenção, o qual leva em conta a existência de uma subjetividade compartilhada. Por isso, um modo somático de atenção significa não apenas atenção relativa ao próprio corpo, mas inclui atenção aos corpos dos outros, o que possibilita a constituição de vínculos sociais e seu entendimento como uma construção sociocultural.

\subsection{A intercessão como forma de anunciação divina}

A intercessão, de acordo com o CATECISMO DA IGREJA CATÓLICA (2003), é um tipo de oração que deve estar presente na vida cotidiana de um cristão. Especificamente, ela é uma oração de pedido, na qual se pede o bem para o outro, mesmo àqueles que fazem mal. No grupo Ágape,

\footnotetext{
${ }^{20}$ Para mais informações consultar os escritos de Bourdieu.
} 
eles possuem um grupo reduzido de pessoas, cerca de oito, só para realizar orações a favor de todo o grupo. É nesse momento de contato com Deus que muitas coisas são definidas para a coletividade Ágape.

Fui informada que aos domingos, a intercessão se iniciava às 19h. Então me preparei para chegar às dependências da Igreja um pouco mais cedo. Ao chegar no local, me dirigi à dependência da paróquia destinada à catequese, torcendo para que aquele fosse o lugar preferido para que os servos se encontrassem antes de qualquer atividade do grupo, ou melhor, torcendo para encontrar algum servo do grupo de oração por lá.

Olho para dentro da dependência da catequese, havia João (o subcoordenador da intercessão) e mais dois moços. Cumprimentei todos e iniciei uma conversa com João, ele me informou que estava esperando outras pessoas. Logo, Sandra - coordenadora da intercessão chegou, seguida por Ana (serva da intercessão) e depois por Marcela (também serva do mesmo ministério). Com a chegada dessas pessoas, e pelo adiantado da hora, Sandra convidou a todos para entrar.

Chegamos à capela. Sandra abriu a porta, que se encontrava somente encostada e todos entraram. Os servos entraram primeiro, eu fiquei observando a técnica por eles apresentada para adentrarem àquele espaço religioso. Todos deram um passo largo à frente com a perna direita $e$, dirigindo o joelho esquerdo ao chão, ao mesmo tempo que olharam fixamente para frente, fazendo o sinal da cruz com a mão direita. Ao fazer o sinal da cruz, tocaram primeiramente à testa, depois o abdômen, o ombro esquerdo e o direito, nessa ordem. Ao terminar de fazer o gesto em sinal da cruz, sem necessariamente tocar o joelho esquerdo ao chão, já se levantaram e se dirigiram à esquerda/sul da capela.

Ao ver essa cena, recordei do clássico estudo desenvolvido por Robert Hertz (1980) sobre a polaridade religiosa. Ao tratar da destreza como um critério universal estabelecido culturalmente, o autor enfatiza que ao privilegiarmos um lado do corpo em detrimento do outro, assumimos explicações "divinas" para justificar o critério de nossas escolhas. Isso porque os seres humanos constroem culturalmente - sobretudo as culturas ocidentais - explicações opositivas, dividindo a direita e a esquerda como contrastantes, portanto, não complementares. Assim, os elementos de ordem material, entre eles, o corpo é visto de maneira bipolar, ao tempo em que se tem a associação, culturalmente dada, de que o lado direito do corpo é o ideal de destreza, retidão, sendo considerado o lado sagrado, enquanto ao esquerdo são atribuídas características nefastas, impuras e, algumas vezes, maléficas. Isso explica por que ao entrar na capela dá-se o passo primeiramente com a perna direita e o gesto representando a cruz é feito também com a mão do mesmo lado reconhecido como sagrado. 
$\mathrm{Na}$ capela todos olhavam fixamente à frente, pois nessa direção, havia um sacrário ${ }^{21}$. Olhei para os servos, eles estavam conversando e então me dediquei a observar como a decoração, em especial a iluminação, dava encanto e magia àquele lugar. Era detalhadamente decorado e moderno. A forma da capela era retangular. A porta ao fundo/leste, pela qual passamos para entrar, encontrava-se centralizada na parede lisa e branca. À direita/norte, havia um jardim de inverno, com poucas plantas baixas, com cascas de madeira e pedras brancas decorando e bloqueando a visão direta para o chão de terra. A parede desse lado era enfeitada com textura feita de retângulos de madeira escura. O teto nessa extremidade sagrada era fendido, dando acesso do olhar direto ao céu. Somente uma pilastra branca dividia a parte da capela da parte do jardim de inverno. À esquerda havia bancos (móveis) de madeira, compridos e sem apoio para as costas. A parte da frente era trabalhada no gesso, a fim de aconchegar o sacrário e um crucifixo, dentro de um recorte retangular. Diante do sacrário havia um pequeno altar de mais ou menos um metro e meio de altura, por dois metros de comprimento e dois metros de largura, feito de madeira marrom. Mas o encanto e magia se davam mais pelo efeito da iluminação.

O recorte retangular possuía iluminação embutida, de forma que saiam luzes nas laterais do retângulo e detrás da cruz. Ainda assim, havia pontos de iluminação que saiam de cima e de baixo de toda a parede frontal/oeste. A capela inteira possuía iluminação em pontos de luz. Cada conjunto de luz podia ser ligado em um interruptor que se localizava do lado direito/norte da porta da capela.

Ao perceber que havia um ar condicionado acoplado no lado direito da capela, próximo à fenda no teto, dirigi-me em direção ao mesmo para conferir se realmente havia um ar condicionado e um jardim de inverno com o teto aberto. Descobri que tinha. Pensei comigo, "que desperdício de energia, mas ficou bonito com a natureza ao fundo".

Sandra comentou que possivelmente não viria mais ninguém, vez que eles estavam esperando somente mais duas pessoas, que até aquele momento não haviam chegado. Posicionamo-nos em frente ao altar em semicírculo. Fizemos o sinal da cruz de modo mais complexo (diz-se "pelo sinal da santa" cruz desenhando uma cruz com o polegar direito na testa, "livra-nos Deus nosso Senhor" desenhando na boca, "dos nossos inimigos" desenha no coração, e fizemos o sinal da cruz simples, dizendo em "nome do Pai" tocando as pontas dos dedos da mão direita na testa, "em nome do Filho" tocando o abdome e "em nome do Espírito Santo" tocando os ombros, primeiro o esquerdo e depois o direito). Incentivados por Sandra, seguramos as mãos uns dos outros. João e Marcela, por terem ficado nas pontas, colocaram as mãos sobre o pequeno altar. Ficamos assim, João à esquerda, com a mão esquerda no pequeno altar e a mão direita com a minha mão esquerda, a minha mão direita com a esquerda da Ana, Sandra entre Ana e Marcela, e sua mão direita com a mão esquerda da Marcela, e a mão direita da Marcela no pequeno altar. ${ }^{21}$ Sacrário é o lugar da capela que se abriga a hóstia, o pão, que também é denominado pelos
católicos como o "corpo de Cristo". 
O ritual da intercessão iniciou-se com orações formais presididas por Sandra. Recitou-se o Vinde espírito Santo ${ }^{22}$, Pai nosso ${ }^{23}$ e Ave Maria ${ }^{24}$. Sandra pediu para que entregássemos a vida de cada servo do grupo e intercedêssemos por eles. Entregaram cada um deles, dizendo os nomes um a um. Normalmente, iniciavam suas orações com "eu te entrego Senhor" ou "eu te entrego meu Deus" ou "eu te entrego Jesus" e falavam um nome. Eram realizadas falas individuais de maneira que quem iniciava depois repetia o nome que tinha acabado de ser dito, nessa dinâmica, pareceu que um a um, os servos iam lembrando os nomes dos outros. Em seguida, eles entregaram cada namoro, "te entrego Senhor/meu Deus/Jesus" e dizia o nome do casal, falavam o nome de todos os casais. Entregaram também as brigas do ministério de música, pediam para que Deus reunisse o ministério de música que se encontrava dividido.

Nesse momento de orações espontâneas, observou-se que, à medida que a oração ia fluindo, mais intensa ela se tornava. A intensidade ia se manifestando por alguns fatores ou técnicas, como o aumento do volume da voz, contração de músculos faciais, deslocamentos pendulares (laterais ou frontais) e por movimentos repetidos e intensos realizados com o braço, sendo as três últimas técnicas manifestadas de forma mais intensa no corpo. As técnicas corporais, de acordo com Mauss (2003, p.211) são "as maneiras como os homens, sociedade por sociedade e de maneira tradicional, sabem servir-se de seus corpos", de forma que o corpo é simultaneamente um objeto primordial e uma ferramenta de ação cultural. Csordas (2008) anuncia que, para os carismáticos, o poder de Deus se manifesta através de técnicas corporais que ele ainda chama de técnicas retóricas de empoderamento, pois o corpo é o meio mais concreto e imediato de persuadir as pessoas da realidade do poder divino.

Ao dar seguimento na intercessão, Sandra solicitou para que pedíssemos pela vinda do Espírito Santo sobre nós e sobre cada um dos integrantes (sem dizer os nomes dessa vez). Seguiu o momento de oração com uma música que tinha como letra a invocação do Espírito Santo de Deus. Todos cantaram e logo começaram a orar em línguas.

Durante o momento que eles oravam em línguas, pôde-se perceber que todos realizavam movimentos pendulares e os que oravam com mais volume, possuíam simultaneamente em seu

\footnotetext{
${ }^{22}$ Vinde, Espírito Santo, enchei os corações dos Vossos fiéis, e acendei neles o fogo do Vosso amor. Enviai, Senhor, o Vosso Espírito, e tudo será criado, e renovareis a face da terra. Oremos. Ó Deus, que instruístes os corações dos Vossos fiéis com a luz do Espírito Santo, fazei que apreciemos retamente todas as coisas segundo este mesmo Espírito e gozemos sempre de Sua consolação. Por Cristo Senhor nosso. Amém.

${ }^{23}$ Pai nosso, que estais no céu, santificado seja o vosso nome, venha a nós o vosso reino, seja feita a vossa vontade assim na terra como no céu. O pão nosso de cada dia nos dai hoje, perdoai-nos as nossas ofensas, assim como nós perdoamos a quem nos tem ofendido e não nos deixei cair em tentação mas livrai-nos do mal. Amém.

${ }^{24}$ Ave-Maria cheia de graça, o senhor é convosco, bendita sois vós entre as mulheres, bendito é o fruto do vosso ventre Jesus. Santa Maria mãe de Deus, rogai por nós pecadores agora e na hora de nossa morte. Amém.
} 
corpo alguma das outras técnicas corporais mencionadas anteriormente, como a agitação do braço ou a contração da face. Claramente todos ali estavam em poder do Espírito Santo, sendo que havia alguns que se manifestavam de formas diversas tal empoderamento.

Uma das participantes, Ana, interrompeu a oração em línguas com uma palavra de conhecimento. Segundo Csordas (2008), a palavra de conhecimento é uma informação recebida espontaneamente com a instrução do alto. Ana disse que Deus Ihe inspirava naquele momento para que intercedêssemos pelo retiro, e começaram a pedir a Deus para que Ele abençoasse o retiro, e que acontecesse conforme os planos de Deus.

Sandra, nesse mesmo caminho de Ana, interveio na oração e aconselhou que pedíssemos que Deus desse forças aos servos, pois o retiro era um acontecimento muito forte, ela disse isso com um tom de choro. Segundo Pereira (2009), o choro é também uma técnica que corresponde à eficácia do contato com o sagrado. Sandra manifestou exatamente naquele momento todas as técnicas identificadas até agora, contração da face, sentimento de choro, agitação das mãos e movimentos pendulares para frente.

Ela deu continuidade à sua fala executando todas essas técnicas. Disse que no retiro passado houve muitas tribulações físicas fortes, pois muitas pessoas ficaram doentes. Olhei diretamente para ela e percebi que olhava diretamente para João e que o mesmo assinalava afirmativamente com a cabeça. Ana que se encontrava de olhos fechados, abriu-os e falou olhando pra mim e depois para o João, "até eu passei mal'. Sandra abaixou a cabeça, franziu a testa e deu prosseguimento à sua oração com uma voz chorosa, retrucando: "quantas pessoas ficaram gripadas e indispostas? Mais da metade dos servos, Senhor! Não deixe que isso aconteça novamente, Senhor?". Após tal fala, as pessoas começaram a rezar junto com ela, pedindo que Deus afastasse as tribulações, todo o mal do próximo retiro e também para que o retiro acontecesse corretamente.

O mal é ontologicamente real e, para os carismáticos, pode ser corporificado em seres ativos e intencionais, que são os espíritos malignos (CSORDAS, 2008). Um demônio, em algumas circunstâncias, pode exercer influência em uma pessoa através de certas vulnerabilidades. Para os carismáticos, há um significativo paralelismo entre demônio e doença. No entanto, a experiência de ficar doente pode ser organizada e tematizada de acordo com a orientação cultural. Enquanto esses intercessores interpretam a experiência da doença como uma ação demoníaca, outros poderiam dizer que um deles adquiriu um vírus resistente e, por eles se encontrarem com frequência para realizar atividades religiosas em conjunto, eles poderiam ter contaminado uns aos outros.

Ana interrompeu a oração pelo retiro ao ter uma experiência imagética, ela disse estar visualizando uma palavra. Nas palavras dela "estou visualizando uma palavra, Deus está enviando a seguinte passagem: levanta-te pois a alegria do Senhor é a vossa força", após um breve silêncio ela completou "talvez seja essa a palavra que Deus quer que seja tema do nosso retiro". 
Nesse caso, a palavra obtida pela experiência imagética se mistura com a profecia. Ana disse ter visto em sua cabeça, uma imagem que continha a frase, e não ouvido Deus dizer. O fato de ser uma imagem caracterizada pela experiência imagética, segundo Csordas (2008), demonstra que em tal experiência há a suposição de que Deus (ou outro ser superior) escreveu aquilo (talvez como um bilhete). Assim, transmite-se a ideia de que não foi Ana quem aconselhou, mas Deus que interveio. Essa apropriação das palavras de Deus por um indivíduo, que se considera eleito, é a definição de profecia. No entanto, é interessante notar que a interpretação dada à palavra de Deus por ela recebida, estava diretamente relacionada com o tema da oração, o retiro.

Após a recepção e a interpretação da palavra, João sugeriu finalizar a oração, pois a missa iria começar. Então, agradecemos pela intercessão, pela graça que Deus estava derramando sobre nós (os intercessores), os servos, o grupo de oração e o retiro. Rezamos um Pai Nosso, uma AveMaria, fizemos o sinal da cruz e nos dirigimos ao banco no fundo da capela.

Antes do início da missa, todos conversaram sobre o possível tema do retiro, que tinha aparecido nessa intercessão. Os quatro concordaram que o tema fosse essa palavra recebida pela experiência imagética de Ana e, ainda, Sandra comentou que Bárbara (líder do ministério de música) tinha dado uma ideia semelhante durante a reunião anterior. Na conversa, eles compreenderam que Deus realmente queria que a palavra recebida na intercessão fosse tema do retiro, pois tal ideia já havia sido discutida como um possível tema do retiro por outros servos.

Todos saíram da capela fazendo o mesmo gesto quando entraram. Dirigiram-se à porta, antes de sair, viraram-se de frente para o sacrário, olharam fixamente para frente, deram um passo à frente com a perna direita, dirigiram o joelho esquerdo ao chão,e ,enquanto isso, fizeram o sinal da cruz com a mão direita.

Notou-se que a intercessão se utiliza de muitos elementos típicos da renovação carismática como a oração em línguas, palavra de sabedoria, experiência imagética, profecia e discernimento da palavra em prol do coletivo. Apesar de haver estudos que apontam e definem alguns desses elementos, como Csordas (2008) e Pereira (2009), tais estudos exemplificam tais experiências como de uso individual, aqui podemos ver tais experiências voltadas para um grupo de pessoas.

Observou-se também que a manifestação demonstrada pelo uso das técnicas corporais utilizadas por cada participante, ratifica a noção de que a experiência corpórea é um resultado da relação com os outros no momento da interação social. Tem-se um comportamento esperado, em que se almeja a visualização de técnicas próprias da RCC, que acabam por se marcar nos corpos como forma de demonstrar a aproximação com os postulados do catolicismo e, com o MRCC. Assim, todas as técnicas corporais realizadas foram formas de expressar a presença da coletividade ou da comoção social nas individualidades de cada um dos participantes. Em outras palavras, as técnicas corporais foram utilizadas, até certo ponto de forma coletiva, pois todos realizaram movimentos 
pendulares, refletindo em seus corpos a intensidade do contato com Deus, por intermédio do Espírito Santo. O que não quer dizer que havia pessoas com mais ou com menos contatos, mas que os que mais se expressaram com o corpo foram os que também mais o fizeram por meio da fala (em tempo de fala e volume), durante a oração de intercessão, como também foram os que mais se utilizaram de elementos típicos da Renovação Carismática.

$\mathrm{Na}$ intercessão desses jovens carismáticos, o corpo, a linguagem e os sentimentos constituíram elementos de uma relação entre homem e Deus, realidade essa produtora de orações que conduziram (individualmente) e que eles esperavam que iriam produzir (coletivamente) experiências místicas. Além do mais, foi através da intercessão que o tema do retiro foi discernido, isto é, o tema aparece, nesse contexto, como resultado de uma orientação divina, como a vontade de Deus.

\subsection{A missa de domingo à noite}

A missa se apresenta também como uma atividade que compreende o cotidiano de fiéis católicos, considerados praticantes. No cotidiano dos indivíduos participantes do grupo Ágape, ela pode ser entendida, tal qual enuncia Sofiati (2009), como um movimento pautado não somente nas experiências religiosas, como também na procura da santidade pessoal e na assídua prática sacramental. Ou seja, a missa se constitui como uma prática cotidiana obrigatória, especialmente a de domingo. Nesse trabalho, a missa não será descrita como um ritual, identificando-se apenas alguns elementos - ritos da celebração - que serão aqui interpretados. A opção se deu por conta de dois fatores: (i) quantidade de pessoas que se aglomeram em torno desse rito de celebração, o que dificultaria à análise pormenorizada; (ii) tratar-se de um rito de celebração de caráter católico, mas não exclusivamente carismático e que não compreende uma atividade Ágape. Para o estabelecimento desse recorte seguiu-se pesquisas precedentes realizadas por Maués (2000 e 2003), Steil (2006), Csordas (2008) e Sofiati (2009).

Assim, ao sair da intercessão, Ana me encontrou no caminho para fora e pediu para que eu a seguisse, assim eu fiz. Saímos da dependência da catequese e entramos na igreja pela porta lateral. Todas as portas laterais da igreja são de vidro, duplas, e de correr. Era uma igreja grande e moderna em relação às que eu já havia entrado, especialmente as goianas. Lembrava um pouco o estilo de templos evangélicos por conta da riqueza de elementos modernos, no entanto, assim como toda paróquia católica, havia imagens pintadas ou esculpidas em todas as direções em que se olhava.

Concentrei-me em acompanhar o percurso da Ana e logo identifiquei algumas pessoas do Ágape. Eles se encontravam numa região mais centralizada da igreja, exatamente ao lado da equalizadora de som. A mesa ocupava um espaço que caberiam quatro a cinco bancos de madeira, $o$ que daria para acomodar de vinte a trinta pessoas, naquele lugar. Praticamente todos os servos 
estavam sentados ali, e que posicionaram bíblias nos bancos para guardar o lugar dos que ainda não havia chegado. Sentei-me ao lado deles. O modo como a igreja se encontra arquitetada, bem como a centralidade ocupada pelos cânticos durante o rito de celebração, especialmente aos domingos, reflete a importância devotada à música na RCC. De acordo com Bianconi (2008), a musicalidade é um elemento vital de caracterização dos ritos de celebração de natureza carismática.

No entanto, apesar do grande esforço para que a comunidade participasse da missa, por meio dos cânticos e das coreografias a serem seguidas e que são especialmente montadas pelos Servos do Ágape, a participação da comunidade restringia-se às palmas. A comunidade se levantou e tentou coreografar sem sucesso as músicas, em geral as pessoas ficavam mais nas palmas.

As palmas também se manifestam com mais clareza, como um elemento da interação, vez que se propagam como resposta a algum pedido do celebrante, que diz "palmas pra Jesus" e todos batem palmas, ou do cantor que pede para as pessoas ficar de pé e acompanhar a música, mas não se sabe a coreografia, então batem palmas.

As palmas são técnicas corporais importantes entre os carismáticos. Elas ocorrem frequentemente como parte de acompanhamento de diversos cantos que são entoados nos diferentes rituais. "As palmas podem ocorrer em várias situações, inclusive durante a missa, em resposta a certos atos rituais ou palavras do sacerdote" (MAUÉS, 2007, p.128).

Merece também destaque o trabalho realizado pelos servos do Ágape em diversos momentos, como a acolhida na missa. Acompanhei o trabalho de acolhida de uma das servas, Bárbara.

Enquanto conversávamos, Bárbara parava para apertar a mão, com um sorriso e dizeres como "boa noite" e "boa celebração". Pude, no entanto, perceber que ela aparentava ter um semblante triste, mas logo que alguém se aproximava da porta, ela se recompunha com um sorriso, como se fosse a sua obrigação representar um estado de felicidade no momento da acolhida.

Os elementos carismáticos evidenciados por meio das técnicas corporais, que foram passíveis de serem identificados durante a missa foram a acolhida, as danças e as palmas. Esta acolhida por expressões corporais e apertos de mão é a que se mostra também como um lugar privilegiado de interação social, ainda que rápida.

No caso em tela, percebeu-se que Bárbara fez todo um esforço para que todos acreditassem que ela estava feliz com a presença de cada um dos fiéis durante a missa, todavia o seu estado de felicidade correspondia muito mais a um processo de constituição de uma representação, como se fosse a produção de uma cena teatral. Assim, faz sentido o que diz Goffman (2013) ao afirmar que um indivíduo tende a influenciar o modo com que os outros o verão pelas suas ações o que nem sempre é feito com total consciência. Para isso, a pessoa agirá de forma teatral 
para emitir uma impressão, a fim de obter dos observadores as respostas de seu interesse, nesse caso, achar que ela está feliz por que ofereceu um sorriso. O corpo, dessa maneira, se mostra como um importante meio para se estabelecer relações sociais e induzir no outro as respostas que se revestem de interesses projetados pelo grupo social - Ágape - do qual ela é parte integrante, estando naquele instante

\subsection{Encontros de sábado à noite}

O auditório da paróquia Sagrada Família torna-se o espaço destinado para os encontros dos servos no sábado à noite. Todos são recepcionados com um largo sorriso e palavras de boasvindas, por cada um dos membros integrantes da acolhida do Ágape.

O momento de recepção, que no Ágape é feito constantemente e em vários ambientes, é chamado acolhida. É costume entre os carismáticos, de acordo com Maués (2007), que a recepção das pessoas seja feita

[...] pelo menos, com apertos de mão e, muitas vezes, com abraços, mais ou menos formais - mas, muitas vezes, bastante calorosos, dependendo da pessoa que recebe ou do grau de intimidade existente. Esse é o primeiro toque corporal, que frequentemente é acompanhado da fórmula: "A paz de Cristo" ou "A paz do Senhor. (MAUÉS, 2007, p. 124).

No Ágape, raramente foi dito paz de Cristo ou paz do Senhor, e vale destacar a presença constante e, às vezes constrangedora, do sorriso, que aparenta ser para o Ágape, uma forma de comunicação corporal significante. Quando entrevistei Mateus, coordenador da acolhida, perguntei o que ele achava da abordagem corporal realizada naquele momento. $E$ eis o que disse ele: "É tudo 'né'! É a porta de Deus pras pessoas, é a hora que Deus é bom. Por isso a gente fala 'né'?! Que a gente tem que se preparar bem, é a hora que a gente vai mostrar que Deus é bom. Tipo assim, a pessoa chega ali do jeito que ela estiver. No momento que ela 'tá' muito bem, ela pode ficar melhor. Ou ela pode tá mal, aí você vai dar um sorriso, um abraço, não precisa também ser palhaço. É diferente ser alegre. Você pode mostrar uma alegria no abraço, não falar nada, só falar assim 'seja bem-vindo'. Nisso a pessoa quebra a timidez. A gente utiliza muito isso 'né'? É a libertação da pessoa, se você tiver bem, se você tiver preparado, 'num' aperto de mão você pode libertar a pessoa".

$\mathrm{Na}$ condição de observadora, eu diria que o sorriso, o aperto de mão e o abraço seriam técnicas corporais utilizadas com maior ênfase, com a finalidade de propiciar a interação e aproximação com a comunidade, pois como relata Sofiati (2009), os católicos vivem um processo de perda de fiéis e a RCC tem apresentado eficiência no combate dessa situação. 
Porém, ao contrário do que imaginei no primeiro momento, a fala de Mateus, demonstra que por trás do abraço, do sorriso e do aperto de mão, há um significado místico das técnicas corporais. Um simples gesto, sem a necessidade de qualquer comunicação verbal, pode fazer a reviravolta na vida da pessoa, propiciando para quem chega, um momento íntimo com Deus, que pode levar à libertação.

Apesar de ter sido recepcionada poucas vezes da forma que descrevi, talvez por chegar mais cedo que o normal, percebi que eles sempre insistiam em me cumprimentar se utilizando das técnicas corporais descritas. Mesmo depois de já estar sentada em uma cadeira dentro do auditório, os servos sempre vinham me cumprimentar.

Após ter sido acolhida pelos servos que têm essa função específica no Ágape, ou seja, se encontram preparados para isso, entrei no auditório e logo observei que as cadeiras se encontram em dois blocos, formando um corredor ao centro. A disposição das cadeiras dependia do que foi pensado para o dia, ou da quantidade de pessoas que eles achavam que teria no grupo. Se se seria um dia que subiriam com uma hóstia, um dia de adoração, as cadeiras estariam em semicírculo, ou se seria um dia após um feriado, por exemplo, as cadeiras se posicionariam ao centro.

A primeira atividade que se realizou dentro do auditório foi o terço. Entre 19h e 19h30, algum servo se posicionava à frente do altar, a fim de iniciar a oração do terço. Na maioria das vezes, essa oração era ministrada por uma dupla de servos, formada por um homem e uma mulher. O terço que descreverei, foi orientado por Sandra e João, pois os dois foram os que mais administraram o terço no Ágape.

Os dois se posicionaram ao centro do corredor com o terço em mãos. Sandra disse "vamos ficar de pé para iniciar o santo terço" e todos se levantaram. Ela fez o sinal da cruz da forma mais complexa e todos a seguiram. Sandra inicia a oração do credo ${ }^{25}$ e todos acompanham. Rezou-se o Pai Nosso, mas antes de rezar Sandra disse "um pai nosso em honra à santíssima trindade". Após o pai nosso, rezou-se três Ave-Marias, antes de cada uma dizia-se, "primeira ave-maria é em honra a Deus Pai que nos criou", "a segunda é em honra a Deus Filho que nos remiu" e a "terceira em honra a Deus Espírito Santo que nos santifica". Todas essas orações foram realizadas em coro e em pé.

João contemplou o primeiro mistério ${ }^{26}$ "no primeiro mistério contemplamos a anunciação do anjo Gabriel a Nossa Senhora" e disse que todos podiam se sentar. Após isso completou "nesse

${ }^{25}$ Creio em Deus Pai, todo poderoso, criador do céu e da terra e em Jesus Cristo seu único filho, Nosso senhor, que foi concebido pelo poder do Espírito Santo, nasceu da virgem Maria, padeceu sobre Pôncio Pilatos, foi crucificado, morto e sepultado, desceu a mansão dos mortos, ressuscitou ao terceiro dia, subiu aos céus e está sentado à direita de Deus Pai, o todo poderoso de onde há de vir a julgar os vivos e os mortos. Creio no Espírito Santo, na Santa Igreja Católica, na comunhão dos Santos, na remissão dos pecados, ressureição da carne, na vida eterna. Amem!

${ }^{26}$ Aos sábados, foram contemplados os mistérios gozosos, que são os que anunciam o nascimento de Jesus. No entanto, a Igreja Católica Romana, possui quatro conjuntos distintos de mistérios. São 
mistério, os da direita iniciam [as Ave-Marias] comigo e os da esquerda respondem com Sandra e todos rezam juntos o Pai Nosso". Ao final, rezou-se o Glória ao Pai ${ }^{27}$, com uma pequena reverência com a cabeça, ao início da oração, o "Meu Bom Jesus ${ }^{28, " ~ e ~ J o a ̃ o ~ i n v o c o u ~ o s ~ s a n t o s ~ d e ~ s u a ~}$ preferência, como Santo Antônio, e todos responderam "rogai por nós". Após invocar os santos, a fala passou para outra pessoa da dupla, nesse caso, a Sandra. Ela seguiu a mesma sequência, contemplou o segundo mistério, explicou a forma que seria rezado "dessa vez, o bloco da esquerda puxa as Ave-Marias comigo", o bloco da direita respondeu com João, ao final, rezou o Glória ao Pai, o Meu Bom Jesus e pediu a intercessão dos santos. Alternou-se a fala entre eles e as dinâmicas de se rezar. Sendo o quinto mistério, sempre rezado juntos, de joelhos ou em pé. Ao final, ainda rezaram os Agradecimentos $^{29}$ e a Salve-Rainha ${ }^{30}$. João ainda finalizou dizendo "encerramos este terço na proteção de um Deus que é Pai, Filho e Espírito Santo".

Durante as orações do terço, verificou-se a presença de variedade de técnicas. Como já mencionado por Maués (2007), Csordas (2008) e Sofiati (2009), essa diversidade de técnicas anuncia a riqueza da prática, como um momento de oração ou não. Percebi durante o campo, que o terço sempre era rezado de forma diferente, dividiam-se entre homens e mulheres que iniciavam a oração; por meio da circulação de objetos, em que quem estivesse segurando estaria orando em voz alta; rezando em pares, geralmente formados por um homem e uma mulher.

A dinamicidade dessa oração evidencia ainda mais sua importância para católicos, católicos-carismáticas e, no grupo Ágape. Maués et al. (2002) apontam a oração do terço, como um dos os elementos essenciais de cura entre os carismáticos, utilizado como uma arma espiritual contra o mal. Segundo eles, é uma forma tradicional de oração católica, que se firma entre os carismáticos. Para se rezar o terço, "se utiliza uma espécie de colar de contas, que contém uma medalha, geralmente com o Sagrado Coração de Jesus de um lado e o Sagrado Coração de Maria, de outro, e do qual pende um crucifixo" (MAUÉS et al., 2002, p. 141). É através da oração do terço que os carismáticos buscam o fortalecimento na Virgem Maria e nos Mistérios (luminosos, gloriosos, gozosos e dolorosos), que lembram a vida e a morte de Jesus Cristo.

eles: gozosos, gloriosos, luminosos e dolorosos. A Igreja indica os dias específicos, da semana, que cada um deles deve ser contemplado. No caso do mistério gozoso, ele deve ser contemplado somente aos sábados, ao rezar um único terço.

${ }_{27}$ Gloria ao Pai, ao filho e ao Espírito Santo, como era no princípio agora e sempre. Amém!

${ }^{28}$ Oh meu Bom Jesus, perdoai-nos e livrai-nos do fogo do inferno, levai as almas todas para o céu e socorrei principalmente aquelas que mais precisarem da vossa misericórdia e proteção.

${ }^{29}$ Infinitas graças vos damos, ó Soberana Rainha, pelos benefícios que todos os dias recebemos de vossas mãos maternais. Dignai-vos, agora e para sempre tomar-nos debaixo do vosso poderoso amparo e para mais vos agradecer, vos saudamos com uma Salve Rainha.

${ }^{30}$ Salve Rainha, Mãe de misericórdia, vida, doçura, esperança nossa, salve! A vós bradamos os degredados filhos de Eva, a vós suspiramos, gemendo e chorando neste vale de lágrimas. Eia, pois, Advogada nossa, estes vossos olhos misericordiosos a nós volvei, e depois deste desterro, mostrainos Jesus. Bendito é o fruto do vosso ventre, ó clemente, ó piedosa, ó doce e sempre Virgem Maria. Rogai por nós Santa Mãe de Deus. Para que sejamos dignos das promessas de Cristo. Amém. 
O momento que sucedeu a oração do terço, nos encontros de sábado, recebeu o nome de animação ${ }^{31}$. Foi um momento musical muito descontraído, regado de danças coreografadas, interação social e oração. A animação tinha, em seus momentos iniciais, uma atenção mais voltada para a interação social, pois os animadores incentivaram os participantes a perguntar o nome de quem estava do lado, ou de onde a pessoa tinha vindo. A animação no encontro variou de quinze a quarenta minutos. Em seus momentos finais, ela foi mais voltada para oração, especialmente o louvor e a invocação do Espírito Santo.

$\mathrm{Na}$ maioria das vezes era difícil identificar o ponto exato em que se encerrava um momento de animação e iniciava o dedicado à oração. Mas sabe-se que a animação definitivamente acabava quando a oração que se realizava era a glossolalia, pois uma vez iniciada a oração em línguas, não mais se dançava músicas coreografadas.

Após a animação, sempre tinha um momento dedicado exclusivamente à oração que podia durar de 15 minutos a uma hora, dependendo do que seria trabalhado no encontro. Se fosse uma adoração, um momento de batizo no Espírito ou de cura $^{32}$, o momento de oração podia durar até o fim do grupo, tendo sempre um instrumento sendo tocado ao fundo. Se fosse uma pregação, seriam realizadas orações mais curtas.

Após as orações curtas, na maioria das vezes, tinha uma pregação. O pregador se posicionava à frente do grupo, o animador ou o coordenador do Ágape pedia para que todos rezassem por ele. Era realizada a imposição de mãos sem o toque, eram feitas falas espontâneas, e ao fim todos rezavam em coro, uma Ave-Maria. O pregador pegou o microfone e falou cerca de 50 minutos, normalmente sobre como viver uma vida em santidade, e ao falar disso abordou a sexualidade. Ao fim, incentivados pelo coordenador ou pelo próprio pregador todos ficaram de pé e realizaram mais orações espontâneas, orientadas pelo tema da pregação. Posteriormente à pregação, ou adoração, ou batizo no espírito, ou a cura, impôs-se as mãos sobre quem ministrou tal atividade e rezou-se uma Ave-Maria em agradecimento.

Em seguida, o coordenador disse aos participantes que podiam se assentar. Quando todos se encontraram sentados, ele perguntou "quem veio pela primeira vez?" e pediu para levantar a mão. Depois de identificar todos, pediu para que eles se levantassem. Após estarem de pé, ele pediu para ir à frente. Enquanto eles estavam a caminho, o coordenador explicou que queria saber o nome, de onde eles eram e como ficaram sabendo do Ágape. O microfone passou de pessoa para pessoa e cada um informava o que tinha sido pedido. Enquanto eles informavam, algum servo que também se posicionava à frente, entregava uma lembrancinha tirada de uma cesta de palha. Outros servos sem lembrancinha iam à frente para dar um abraço ou um aperto de mão e dizer que eram bem-vindos ao encontro.

${ }^{31}$ Como as danças acontecem na animação será abordado no capítulo 3.

${ }^{32}$ Estes momentos estão descritos no IV encontro Ágape. 
Ao final dos cumprimentos e das lembrancinhas, o coordenador agradeceu a presença, pediu que todos se aproximassem da imagem de Nossa Senhora das Graças, para fazer a consagração à Nossa senhora. Todos se deslocaram para frente. Alguns chegaram a tocar a imagem de gesso, outros tocaram no ombro de quem estava em contato com a imagem e ainda tinha os que preferiram não tocar. No Ágape, a consagração à Nossa Senhora se fazia cantada e dançada.

Após a consagração, realizou-se a oração de São Miguel Arcanjo ${ }^{33}$, nas palavras de Pedro em postura de combate ou de batalha, com uma mão no peito e outra aberta ao lado do ombro, como se fosse um juramento. Terminando a oração, fez o sinal da cruz. Os participantes foram embora. Os ministros de música tocaram mais uma música. As mulheres empilharam as cadeiras enquanto os homens as transportavam para o fundo. Ao finalizar a música de encerramento, os ministros de música guardavam os instrumentos, faziam em círculo, deram as mãos e de cabeça baixa realizaram sua oração final.

O Grupo Ágape possui a oração como atividade central, sendo a consagração à Maria a coroação da reunião. Para Sofiati (2009), a devoção à Maria é uma característica da RCC no Brasil. Desde quando o movimento se inseriu no Brasil, ele abraça Maria como uma identidade carismática. Foram variadas as técnicas corporais utilizadas pelo grupo em devoção a Maria, iniciando pelos vários modos de se rezar um terço e finalizando com uma dança de consagração. Entrega-se o corpo, representado por suas partes, olhos, ouvidos e boca, a sacralidade de Maria. O corpo que, de acordo com Gélis (2008), possui um significado duplo para os cristãos, pois por um lado apresenta um aspecto sagrado por se assemelhar ao corpo de Cristo, o único Deus encarnado, e por outro apresenta aspectos profanos da carne pecadora, assim como todo mortal. Ao ser apresentado à Maria, ele se torna sagrado.

${ }^{33}$ São Miguel Arcanjo, defendei-nos no combate, sede o nosso refúgio contra as maldades e ciladas do demônio. Ordene-Ihe Deus, instantemente lhe pedimos, e vós, príncipe da milícia celeste, pela virtude divina, precipitai no inferno a satanás e aos outros espíritos malignos, que andam pelo mundo para perder as almas. Amém. 


\title{
CAPÍTULO III - COM DANÇAS GLORIFIQUEM O SEU NOME
}

Dançar é imprimir movimento ao corpo. O movimento é a expressão particular de cada ser humano. Dançando se é capaz de revelar suas características mais íntimas. A dança se faz pela realização de movimentos que podem aparentemente não ter funções práticas, mas possuem sentido e significado em si próprios, sendo recriados e revividos a cada momento. O modo como o ser dançante se movimenta, como diversifica o uso do ritmo e suas dinâmicas, como experimenta, ocupa e modifica o espaço, faz com que o movimento adquira plasticidade transformando-se em dança (MACHADO DE VARGAS, 2007).

Como uma técnica corporal, a dança, assim como as demais práticas, constitui-se como as maneiras como os homens se servem de seus corpos, assegurando a eficácia e a tradição (MAUSS, 2003). Nas palavras do autor,

\begin{abstract}
Chamo de técnica um ato tradicional e eficaz (e vejam que, nisto, não difere do ato mágico, religioso, simbólico). É preciso que seja tradicional e eficaz. Não há técnica e tampouco transmissão se não há tradição. É nisso que o homem se distingue sobretudo dos animais: pela transmissão de suas técnicas e muito provavelmente por sua transmissão oral. Peço-vos então a permissão de considerar que adotais minhas definições. Mas, qual é a diferença entre 0 ato tradicional eficaz da religião, o ato tradicional, eficaz, simbólico, jurídico, os atos da vida em comum, os atos morais, por um lado, e o ato tradicional das técnicas, por outro? É que este é sentido pelo autor como um ato de ordem mecânica, física ou físico-química, e é efetuado com esse objetivo. Nessas condições, cabe dizer muito simplesmente: devemos lidar com técnicas do corpo. O corpo é o primeiro e o mais natural instrumento do homem. O mais exatamente, sem falar de instrumento, o primeiro e mais natural objeto técnico, e ao mesmo tempo meio técnico do homem é seu corpo (MAUSS, 2003, p.407).
\end{abstract}

As técnicas corporais nos ajudam a entender o significado da dança como uma prática corporal, pois o dançar se reveste de um conjunto de técnicas. Assim como o aperto de mão, o abraço, o sorriso (presentes na acolhida), a oração em línguas, o choro e o repouso no Espírito; a dança se mostra como uma técnica corporal que assegura eficácia e tradição. Portanto, a dança possui um significado peculiar, singular, no meio católico carismático.

\subsection{Tornando-se servos}

A dança no catolicismo foi retomada com o MRCC. Alguns autores (MAUÉS, 2003, 2007; CSORDAS, 2008; SOFIATI, 2009), ao estudarem o Movimento, relatam a presença da dança. No entanto, não se dedicam profundamente a análise de todas elas. Somente Maués (2003) analisa uma 
delas, que não foi encontrada na presente pesquisa e em sua publicação de 2000 chega a descrever um fragmento de dança, no entanto, dedica seu texto a diversas práticas distintas.

Todos entraram na capela. Notei que sobre o altar se encontravam algumas cruzes utilizadas como adereço cristão, uma bíblia aberta e uma vela muito bonita, acesa. Ao centro do recinto havia três bancos posicionados paralelamente um ao outro.

Qualquer espaço físico pode ser um lugar para dançar. Isso não significa necessariamente que a dança não possa ser executada em um lugar específico, porém, concordando-se com Saraiva et al. (2005), todo e qualquer espaço pode ser visto como propício para a dança. Os conhecimentos desenvolvidos dessa forma abrem um leque para que a dança tenha uma vasta possibilidade para sua realização.

De repente, Cláudia deu boa noite a todos e convidou a ficarem em pé. Disse que fizéssemos a dinâmica da música "o mar se abriu" com os bancos no meio mesmo. O violão começou no ritmo e alguns começaram a balançar com o toque.

A música oferece o papel de apoio e estímulo, não necessariamente o ritmo. Ou seja, não é necessário que o ritmo do dançarino seja o ritmo da música, o mais importante é o fluxo do movimento. Ao dançar o importante é a produção de significados que a dança adquire, ou seja, a intenção que nos move na realização do movimento (SARAIVA et al., 2005).

As técnicas de movimento são um fazer humano cujo resultado se expressa no corpo. A dança possibilita que o corpo seja meio e fim da técnica corporal. Todos os movimentos, por mais simples que sejam, exigem a utilização de técnicas para ser aplicadas, o que possibilita incluir na dança os movimentos do cotidiano.

Após a dança, foi realizada uma dinâmica de reflexão. Foram distribuídos balões, foi dada a permissão para enchê-los, relembrando a história de vida dentro deles. A partir de então foram requeridas várias técnicas com o balão como: andar pela capela olhando para o balão, brincar de manter o balão flutuando no ar, tomar o balão do outro, estourá-lo ou trocá-lo com outra pessoa. Ao fim, partilharam de suas experiências com o balão na mão estouraram o balão.

A dialética do movimento sugere a possibilidade de surgir outros movimentos que não são os convencionais/usuais. Com efeito, a dança, através do improviso, como a experiência com balões, pode-se desatrelar-se dos estereótipos de movimento.

O estourar do balão deu início à uma nova dinâmica, que era tirar uma pequena carta de dentro de um saco, ler a pequena frase que se encontrava escrita de fora e entregar a alguém para que ela lesse o que estava dentro. A pessoa que recebia a carta podia escolher se lia ou não o que estava dentro da carta. Sandra começou e a dinâmica foi se passando, até ela receber um papel. Mas ainda havia algumas pessoas que não haviam participado da dinâmica, falaram que era pra eu 
iniciar novamente, eu disse que não conhecia muito as pessoas. Aí a Bárbara me disse que era pra eu fazer assim mesmo. Então peguei o papel, li em voz alta e entreguei à pessoa que estava à minha frente, no caso Mateus. Ao entregar o papel, Cláudia disse que foi corretamente endereçado, que a frase era a cara dele. Eu disse que o escolhi só porque eu o tinha visto primeiro. Então a dinâmica continuou até Cláudia retirar um papel e entregar a mim. Mas ainda faltava João e novamente disseram que era para eu tirar. Eu tirei e li, muitos riram, e falaram que era a cara dele. Em seguida, Pedro pediu para que os servos iniciantes se sentassem nos três bancos posicionados ao centro da capela. Quatro pessoas se levantaram, Felipe, Marcela, Lucas e Tiago. Paulo cantou uma música que dizia sobre a importância do servir a Deus. Ao fim da música, Pedro pediu para que rezássemos para os servos, as pessoas impuseram as mãos de longe e disseram orações espontâneas.

Depois cantaram uma música bonita sobre o servir e sobre a cruz. Alguns servos novos choraram nessa hora, mas todos espontaneamente se levantaram e pegaram. Ao notar que todos pegaram, Pedro disse que não colocaria a cruz no pescoço de ninguém, pois não eram obrigados a usar. Coloquem vocês mesmos no pescoço de vocês e usem quando quiserem.

Cantaram mais uma música e algumas pessoas se aproximaram para abraçar e falar coisas, que não davam para ser ouvidas por mim, aos novos integrantes. Depois desse momento, Pedro perguntou se todos estavam felizes naquele momento e todos sorriram. Ele disse que esse foi um momento de alegria. Reunimo-nos em círculo novamente, fizemos mais duas orações formais, Pai-Nosso e São Miguel Arcanjo, fizemos o sinal da cruz e fomos embora.

Nessa adoração notou-se uma configuração muito semelhante ao dos encontros de sábado à noite, só que no lugar da pregação (ou oração) foram realizados três momentos, a dinâmica com balões, a atividade com as cartas e um momento muito íntimo aos servos neófitos. Sendo que esse último parece um momento de iniciação de quatro servos.

Como se pode perceber, trata-se de um ritual de iniciação marcado pelo nascimento dos servos. Para as pessoas que adotam a religião como prática em suas vidas determinados momentos são tratados como especiais. Pode-se dizer que o ritual de iniciação está entre estes momentos especiais. Nesse momento do nascimento, o servo morre para a vida profana e nasce para a vida sagrada, que será uma forma de partilhar sua felicidade com Deus, encaminhando-se para uma existência santificada. Assim, o iniciado não é somente um ressuscitado, mas também um conhecedor das crenças e rituais. De modo que a iniciação se equivale ao reconhecimento do amadurecimento espiritual daquele neófito (ELIADE, 2008).

Os iniciados, como os servos do Ágape, cujo ritual de iniciação foi anteriormente descrito, agora estão salvos de todo o mal, sendo assim o simbolismo do nascimento acompanha sempre o da morte, que carrega o significado de superação da condição profana, não santificada e cego para o espírito, como já enunciava Eliade (2008) em seus estudos. 
Merece destaque no ritual de iniciação dos servos a forte presença da cruz como um elemento de devoção e de forte apelo religioso. A cruz, na descrição do ritual de iniciação, aparenta ser o elemento chave. Não se trata apenas de um objeto, ela representa a morte e a ressurreição, simultaneamente. De acordo com Gélis (2012), a representação da cruz traz como informação central a noção de que o corpo de Cristo se encontra no centro da mensagem cristã. É pois um corpo que nasceu na terra, viveu e morreu, consumado no sofrimento de sua missão. De forma que os instrumentos que martirizaram a carne de Cristo e o levaram à morte foram considerados, pela Igreja Católica, como armas da luta vitoriosa contra as forças do mal - satanás -, e merecem ser honradas por todos aqueles que creem no Deus cristão e buscam a existência santificada.

Também foi evidenciado que durante todo o ritual houve a presença da musicalidade. Dança-se com a música, reza-se com a música, realizam-se reflexões com a música e ao iniciar um servo não poderiam faltar músicas. Músicas que muitas das vezes suscitam alguma técnica corporal, como o choro durante a iniciação, ou como os movimentos pendulares ou até que levam a uma oração em línguas, cantada.

\subsection{IV encontro Ágape}

Os membros da Renovação Carismática se reúnem com frequência em encontros de oração na forma de retiros, visando aprofundar o conhecimento de Renovação. Tais encontros ocorrem nos fins de semana e em média uma vez por ano. Geralmente eles são organizados para atender o maior número de pessoas possível afim de realizar dias de oração semelhantes aos que ocorrem nos grupos de oração (RENOVAÇÃO CARISMÁTICA CATÓLICA BRASIL, s/d.).

A fim de realizarem a preparação para o retiro, que teve como mensagem orientadora a imagem recebida por Ana, o tema do IV retiro Ágape "levanta-te pois a alegria do Senhor é a vossa força", foram realizadas uma série de atividades, uma preparação mais formal, que ocorreu um mês antes do retiro; vigílias e momentos de adoração. O objetivo desses encontros anteriores ao retiro era tocar o coração de cada participante, a fim de o retiro fosse um momento de cura espiritual, como relatou-me um dos servos em uma conversa informal.

Chegou-se a observar um dos retiros do grupo Ágape. Ele aconteceu no último fim de semana do mês de novembro e foi organizado em nível paroquial, mas sua divulgação levou até eles, pessoas de todo o estado de Goiás. Os retiros são semelhantes aos grupos de oração, com isso, muitos elementos, que já foram descritos anteriormente puderam ser novamente evidenciados.

O retiro foi realizado em uma chácara situada em um setor periférico da cidade de Aparecida de Goiânia, uma cidade vizinha e muito próxima à Goiânia. Ouvi alguns servos dizerem 
que ela tem capacidade para suportar cerca de duzentos participantes e foi reformada recentemente para ampliar sua capacidade original, que era de apenas cem.

\section{Figura 2 - Espaços utilizados no IV encontro Ágape ${ }^{34}$}

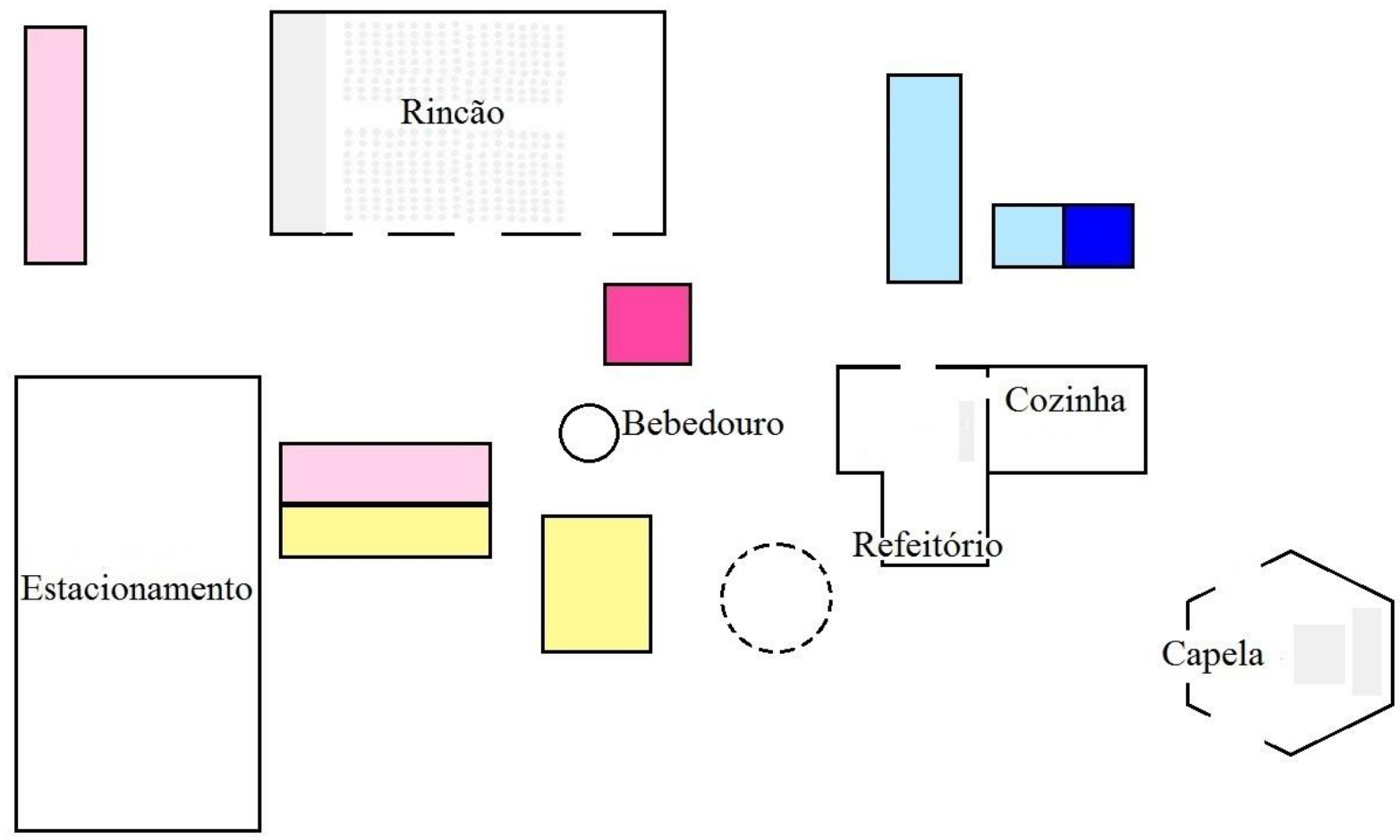

Fonte: Autoria própria (2015).

Ao descermos do ônibus, que nos levou até ao local, já dava para escutar um coro de vozes e palmas compondo uma música que dizia, entre outras palavras, "que bom que você veio". Havia pessoas posicionadas do início ao fim do estacionamento, batendo palmas e cantando.

No rincão - local em que seria realizada a maioria das atividades - havia um grande palco, onde se encontrava o padre. Ele cumprimentou a todos e com algumas orações, deu início às

${ }^{34}$ Os retângulos de cor rosa e que estão em uma tonalidade mais clara são os alojamentos destinados às mulheres. Os retângulos de azul claro são os alojamentos destinados aos homens. Os retângulos amarelos se referem onde foram alojados os servos e alguns palestrantes. Os quadrados são os banheiros, sendo o de rosa escuro, o feminino, e o de azul escuro, o masculino. O círculo menor, que se encontra com sua circunferência contínua, é uma cabana onde está alojado um bebedouro industrial. Já o círculo de circunferência pontilhada é um espaço onde se encontra uma mangueira alta e extensa, que durante o dia, propicia sombra pra mesas que se encontravam dispostas e fixas debaixo da árvore. Também se encontrava um parquinho nesse mesmo espaço de circunferência pontilhada. $O$ hexágono se refere à capela que foi construída nessa forma, com seis lados. Havia o refeitório posicionado ao lado da cozinha. O rincão, onde foi realizada a maioria das atividades do retiro. Por fim o estacionamento, por onde entramos e saímos da chácara. 
atividades naquele dia. Após a oração, ele pediu ao ministério de música a nota mi e começou a cantar a música "incendeia a minha alma",35.

A presença de padres cantores é anunciada por vários pesquisadores (MARIZ, 2005; SILVEIRA, 2004; STEIL, 2004; SOFIATI, 2009) como um elemento característico da Renovação Carismática. A presença de padres que cantam foi fundamental para a popularização do MRCC no Brasil, na década de noventa, de acordo com Sofiati (2009). Atualmente, eles não se configuram mais como o principal meio de adesão dos fiéis, mas ainda assim continuam sendo um fenômeno espontaneamente incorporado pelo movimento carismático (SOFIATI, 2009).

Após cantar, o padre deu início à missa regada de cantos e palmas. O sinal da cruz foi cantado, e além do gesto que acompanha ao fazer o sinal da cruz houve várias palmas. O padre leu a fala de saudação, comum às missas. No ato penitencial, outra música "homem novo",36, cantada de joelhos, por muitos de olhos fechados e alguns contraem alguns músculos da face. Ao levantar, outra música que diz glórias para Deus, dançada com movimentos pendulares laterais e para frente, alguns até faziam o tradicional "dois pra lá e dois pra cá, ${ }^{37}$, braços se movendo de um lado para o outro acima da cabeça e muitas palmas. O padre proferiu mais orações próprias da missa, e Sandra fez a primeira leitura. O Salmo não foi lido, foi cantado por Bárbara. Todos se levantaram para a aclamação do evangelho, que foi dançada com embalos do corpo ao ritmo da música, balanços de mão ao alto e palmas. O padre realizou a leitura do evangelho, e ao fim pediu palmas para a leitura, não satisfeito ele pediu para que se fizesse um grande barulho a palavra de Deus. Ele continuou a realizar sua homilia em meio ao barulho. Sempre ao final de uma ideia, ele tentava interagir com os participantes perguntando "amém?" e pedindo palmas pra Jesus. Ao realizar a oração tradicional da missa ao fim da parte que diz "tomados por uma graça especial", uma moça gritou desesperadamente.

O único grito da moça que deve ter durado cinco segundos não fez com que o padre interrompesse a sua oração, mas me arrepiou até os cabelos da cabeça e fez com que muitos voltassem o olhar para ela. Não era um momento que eu esperava ter uma técnica corporal tão significante, no meio de um momento tão tradicional em uma missa. Após o grito, ela começou a chorar e algumas tosses interrompem o choro. Enquanto isso, o padre continuou a oração e ao fim da mesma, a moça aparentemente desmaiou. Ao notar que a moça se encontrava no chão, o padre disse a todos a sua interpretação para o fato. Ele disse que a libertação estava acontecendo naquele momento. Ele então, em meio a missa, dá prosseguimento a um momento de oração com uma

\footnotetext{
${ }^{35}$ Espírito Santo, vinde falar em mim. Espírito Santo, vinde orar em mim. Vinde curar, vinde libertar nossos corações de toda opressão. Vinde transformar, vem incendiar. Traz fogo do céu nesse lugar. Incendeia minha alma.

${ }^{36}$ Senhor, tem piedade de mim, misericórdia, me manchei, me afastei, venho agora pedir teu perdão. Cristo, tem piedade de mim, misericórdia, te feri, não resisti, volto agora pr'os Teus braços Senhor. Lava-me, purifica-me, Senhor. Quero ser um homem novo, cura meu interior.

${ }^{37}$ Deslocando com dois passos para a direita e depois dois passos para a esquerda.
} 
música "Jesus, neste nome há poder ${ }^{338}$. Com essas músicas, muitas outras pessoas choraram, algumas só com lágrimas e outras com sons estridentes.

O grito da moça apresenta, nesse contexto, um sinal de partida de um espírito maligno, pois, "quando os espíritos são expulsos das pessoas presentes na assembleia, eles produzem uma manifestação física como sinal de sua partida" (CSORDAS, 2008, p.112-3) que pode ser o rugido, tossido, engasgo, vômito ou grito, entre outras manifestações. Ela que em algum momento havia incorporado um espírito maligno se liberta dele com o grito. A tosse também se mostra como uma manifestação de saída de outros espíritos malignos. Já o choro é a manifestação do poder divino. $O$ fato de a moça cair em prantos e tossir pode demonstrar, de acordo com o que anunciam Csordas (2008) e Sofiati (2009), a luta das duas formas opositivas de ser-no-mundo, que se iniciou pela fala do padre "tomados por uma graça especial". De modo que o corpo em estado profano, ao se apoderar da graça, libera de imediato o espírito maligno. Mas o sagrado e o profano ainda continuam em luta pelo corpo da moça, manifestando o choro e a tosse. Até que definitivamente a moça é tomada pela graça sagrada ao cair em solo.

O padre, já habituado com a situação não altera o seu comportamento, ele bem sabe que houve libertação. Ou seja, a moça está se libertando da ação opressora maligna e se empoderando da graça de Deus. Com isso dá continuidade à celebração com uma música que fala do poder de Deus e mais pessoas se demonstram empoderadas através do choro.

Após o momento de oração, que induziu às técnicas de empoderamento, deu-se prosseguimento à missa com o canto de preparação das oferendas com a música "diante do teu altar ${ }^{39}$. As atividades no dia seguinte se iniciaram bem cedo, com o terço e o café da manhã. Logo em seguida, iniciou-se o momento dos cânticos. A música que faz referência ao Espírito Santo, chamada "A corsa",A0, foi a que deu início a esse momento.

Com a música, muitos se envolviam se embalando ao som da canção. No meio da música, Bárbara pediu para levantar as mãos para cima, alguns posicionaram as mãos na altura da cabeça, outros levantaram as mãos o mais alto que podiam, e ainda outros levantaram uma mão somente e a outra foi colocada no peito. Ao final da canção, mas ainda com instrumentos ao fundo, Bárbara pede para ficar em duplas e repetir o que ela diz.

\footnotetext{
${ }^{38}$ Jesus! Nesse nome há poder. O seu nome é poderoso. Sua glória em toda a terra. Há poder no nome de Jesus. O impossível ele pode realizar. O impossível, sim o impossível. O impossível a nós, ele pode realizar.

${ }^{39}$ Diante do teu altar venho me derramar, pois eu sei que nada sou longe do teu amor. Mesmo assim Tu me amas, mesmo assim me alcanças. A minha miséria em tua misericórdia. Eu reconheço, és o meu Deus. Eu reconheço, só Tu é Senhor. Eu reconheço, é o meu Deus, minha alegria, minha paz, meu bem querer.

${ }^{40}$ Assim como a corsa suspira pelas águas, assim suspira minha alma, Espírito de Deus. Oh, oh enche-me Espírito. Oh enche-me Espírito. Oh enche-me Espírito de Deus.
} 
Podemos interpretar as ações praticadas por Bárbara como uma retórica da persuasão. Para Csordas (2008), a retórica da persuasão compreende falas que tentam convencer o fiel da presença de Deus naquele lugar, ou seja, uma fala que tem o intuito de inserir o participante do culto ou louvor em um mundo sagrado, a fim de abrir possibilidades para novas experiências, a cura, por exemplo.

Ao fim da música, a palestrante pediu para todos abrirem os olhos e voltarem-se para o fundo. Quando uma moça vestida de Maria, voltou-se para os participantes e abriu os braços, ficando em uma posição semelhante a de Nossa Senhora das Graças. Amanda disse que quem quisesse podia abraçar Nossa Senhora. Formou-se assim um grande emaranhado de pessoas em torno da representação mariana, o ministério de música voltou a tocar a mesma música sobre Maria. Cerca de quarenta pessoas choravam naquele momento e quase todos se embalavam com o tocar da canção. Ao final da música, rezamos uma Ave-Maria, foi dado um pequeno intervalo e algumas pessoas foram abraçar pessoalmente a representação de Maria.

Nesse momento, o choro surge em resposta à representação Mariana. Trata-se de um momento em que é anunciada a "experiência" com o sagrado. Mesmo que se saiba que não estão de fato em presença da santa, a representação provoca nos participantes o choro, elemento que anuncia a eficácia do contato com o sagrado. De forma que os elementos trabalhados em torno do discurso e da representação (as roupas e o gesto de Maria) inserem os participantes em um tempo e espaço míticos cujo ápice se dá no instante da representação, o que gera neles o sentimento de presença diante de Nossa Senhora e, portanto, o choro.

$\mathrm{Na}$ atividade que se seguiu no rincão, o pregador - Paulo - falou sobre a coragem que se deve ter em assumir Deus na vida. Em meio à pregação, ele pediu para que todos ficassem de pé e levantassem os braços. Logo em seguida, o pregador se utilizou do grito como uma técnica de empoderamento, como se Deus tivesse presente na sua fala, ou como se ele estivesse reproduzindo o poder divino ao dar potência a sua voz ${ }^{41}$.

O pregador pediu para cantar a música "Por hoje não"A2. Enquanto cantavam, alguns servos faziam imposição de mãos em participantes, na maioria das vezes tocava-se no ombro e na cabeça. Quando tocadas, a maioria das pessoas chorava ou contraia a face simulando o início de um choro.

\footnotetext{
${ }^{41}$ Essa técnica produziu em mim uma aversão a essa pregação, mas talvez porque no retiro eu fiquei só observando, se eu estivesse realmente envolvida pela técnica que ele pediu para realizar antes de começar a gritar palavras, talvez eu não teria sentido tamanha aversão.

${ }^{42}$ Deus vê o seu coração sonda com compaixão e sabe o tamanho da sua dor. Ele não pode por limites no Seu amor, pois sabe até onde vai todo pecador. Lágrimas são suor de almas que lutam só. Só Deus pode entender o que te causa dor. Pensa no seu Senhor, recorra ao Seu amor e creia Ele é fiel, justo é o seu amor. Pare de se maltratar, não queira aos outros culpar, diga por hoje não, por hoje eu não vou mais pecar. Estenda a sua mão e abra o seu coração volta pro seu senhor e se abra a restauração. Com Cristo você vai superar, todas as barreiras passar todo o pecado vencer, o novo homem vai nascer.
} 
Muitas pessoas que ainda não foram tocadas por alguns servos se embalavam ao tocar da música. Pude notar uma pessoa sob a imposição de mãos de Sandra repousar, a pessoa estava com a face contraída enquanto Sandra rezava por ela e também realizava movimentos pendulares leves para frente e para trás, a pessoa repousou caindo na diagonal para frente e para o lado, enquanto Sandra tentara amenizar a queda. Em outro caso, antes mesmo de impor as mãos, uma afastou a cadeira de perto de uma moça, que caiu em prantos durante a oração, mas não repousou.

O repouso no Espírito para os carismáticos é uma "experiência marcada pela tomada de todo o corpo do sujeito pelo Espírito Santo - consequência simbólica e física, da entrega de si a Deus" (SOFIATI, 2009, p.59). Nessa experiência mística, a pessoa experimenta Deus, enquanto, simultaneamente, este preenche todo o corpo do primeiro. É um momento especial da experiência religiosa, em que o Espírito rende o corpo humano de suas resistências de forma que a própria pessoa tenha controle sobre o seu corpo e, por isso, acaba caindo ao solo, ou seja, repousando no Espírito (SOFIATI, 2009).

No cantarolar da música, uma moça percebeu que a menina do seu lado estava chorando e a abraçou, e cujo choro se agravara ainda mais tanto que se percebia alguns soluços, sem falar no barulho estridente percebido mesmo de longe. Ao me deparar com esta cena, pude perceber que havia muitas pessoas abraçadas, inclusive servos abraçando os participantes.

O abraço que cura está presente no ritual comum dos carismáticos quando realizado pela pessoa de Jesus através de visualizações (CSORDAS, 2008). No relato acima, pode-se perceber o abraço entre as pessoas como uma técnica de cura, de manifestação do poder divino. Tal fato deve ter sido uma adaptação do abraço de Jesus, que aqui é dado na figura de uma pessoa.

O palestrante interrompeu a música e compartilhou suas revelações recebidas. Disse ele "Deus me revela um jovem que está duvidando do que está acontecendo, está duvidando da ação de Deus aqui, Deus está te dando a graça de se sentir amado". Nesse ponto, notou-se a quantidade de técnicas que os carismáticos usaram em metade de um dia, a fim de convencer os participantes da ação de Deus, técnicas estas que incluem discursos persuasivos como este. E, apesar de tantas técnicas de persuasão utilizadas até agora, o próprio pregador disse que Deus o revelou haver gente ali incrédula relativamente ao que estava acontecendo.

Após a fala do palestrante, os músicos iniciaram outra música, tocaram "Ninguém te ama como $E u^{, 43}$. Ao iniciar a música observou-se que uma moça que estava abraçada com uma serva repousava. Havia um casal de namorados que estavam sentados segurando um na mão do outro, a moça repousava e o homem parecia ficar preocupado com o fato. Várias outras pessoas repousavam

\footnotetext{
${ }^{43}$ Tenho esperado este momento. Tenho esperado que viesses a mim. Tenho esperado que me fales. Tenho esperado que estivesses assim. Eu sei bem o que tens vivido. Sei também que tens chorado. Eu sei bem que tens sofrido, pois permaneço ao teu lado. Ninguém te amo como eu. Olhe pra cruz, esta é a minha grande prova. Ninguém te ama como eu. Olhe pra cruz foi por ti, porque te amo.
} 
naquele momento, cerca de vinte. Cronometrei o tempo de repouso de alguns e pude notar que o tempo mínimo que eles permaneceram ao chão foram dois minutos, e teve uma moça que permaneceu por quase dez minutos.

Ao final da dinâmica, Paulo se aproximou do pregador e pediu a todos para que rezassem para o palestrante. Todos realizaram imposição de mãos e rezaram uma Ave-Maria. Paulo disse que seria dado um tempo para o almoço.

Após o almoço, muitas pessoas aproveitaram o tempo sem atividades dirigidas para conversar, conhecer a capela e os espaços da chácara. Quando retornaram as atividades no rincão, foi feito primeiramente um momento de animação longo, um período de oração que se misturou com a animação, a pregação, os avisos e as orações formais finais, composto por uma Ave-Maria para o pregador. Então foram dados cinco minutos para as pessoas que quisessem ir ao banheiro.

Outra atividade do sábado à tarde se iniciou no rincão com apenas uma música de animação. Em seguida, chamaram o pregador, que fez uma pequena introdução e realizou um momento de oração grande regado de músicas. As músicas juntamente com a oração em línguas fizeram com que todos realizassem movimentos espontâneos, como aqueles repetitivos realizados pelo pé, pelos braços ou se embalar com movimentos pendulares laterais ou para frente. O pregador também pediu para que os participantes utilizassem de técnicas como abrir os braços em posição de cruz e segurassem na mão do irmão para realizar alguma oração determinada. Finalizou-se aquele momento com uma Ave-Maria para o pregador, quando este avisou que as atividades no rincão retornariam em duas horas.

Às $20 \mathrm{~h}$ deu-se início a um show de louvor com o padre. Os shows são frutos de uma ampliação de oferta de eventos disponibilizados pelo MRCC, que por sua vez, são responsáveis pela intensificação de atividades festivas no catolicismo (SILVEIRA, 2011). Aos poucos os participantes iam empurrando as cadeiras para os lados, a fim de modificar o espaço e encaixar suas danças.

Nesse show as músicas não eram coreografadas. Dançava-se livremente com muitas palmas, pulos, deslocamentos no tradicional dois pra lá dois pra cá, fizeram a dinâmica do trenzinho ${ }^{44}$, chegaram até dançar em roda, de uma maneira que me lembrou muito uma roda de hardcore ${ }^{45}$. Em meio à espontaneidade proporcionada por esse momento de show que favoreceu

\footnotetext{
${ }^{44} \mathrm{Na}$ dinâmica do trenzinho, uma pessoa se desloca pelo espaço, andando ou pulando no ritmo da música, enquanto outras se ajeitam e fila atrás dessa primeira, colocando a mão sobre o ombro umas das outras, e acompanham o espaço percorrido por ela.

${ }^{45} \mathrm{Em}$ um roda de hardcore,normalmente vivenciadas em espaços de rock, as pessoas se posicionam em círculo, onde ficam pulando ao ritmo da música, e quando é de seu gosto, eles saem de seu lugar original no círculo para pular ao centro da roda e depois ocupar novamente um lugar na circunferência do círculo. Nos espaços de rock, normalmente observa-se que as pessoas vão pulando ao centro com a finalidade de tocar (com força) com os ombros uma outra. Já nesse
} 
muito a interação entre os participantes através da dança, as pessoas paravam para conversar e muitas vezes dançavam conversando, combinando passos e coreografias que elas mesmas propunham, como bater palmas em cruz, ou chutando na mesma direção ao ritmo da música.

O fervor do entusiasmo juvenil nos shows musicais mais variados é o mesmo, ou seja, para Mariz (2005), não é diferente no catolicismo carismático. No entanto, o MRCC atribui aos seus o sentido próprio de sagrado, apesar do mundo religioso promover experiências similares e muitas vezes idênticas, que geram o mesmo sentimento de êxtase e exaltação.

Após o show, fomos jantar, e em seguida voltamos para o rincão. Lá, arrumou-se rapidamente as cadeiras bagunçadas pelas danças show e o pregador, antes até mesmo de se apresentar, já disse que a noite seria especial para quem estava disposto. A predisposição, para Csordas (2008), é o primeiro elemento necessário para que a cura aconteça. O pregador relatou sobre a importância do passado e pede para todos irem para um parquinho onde ele dá início a cura das memórias.

Na cura das memórias, reza-se pela vida inteira de um indivíduo por etapas,
desde o momento da concepção até o presente. Quaisquer eventos ou
relacionamentos irreconciliados que surjam nessa revisão da história de
vida recebem atenção especial; suspendem-se os procedimentos para um
período de oração e se pede à pessoa que perdoe aqueles que a
machucam. Pode-se solicitar ao suplicante para visualizar qualquer
incidente doloroso que seja descoberto [...]. O curador é auxiliado por meios
sobrenaturais: ele pode declarar uma "profecia", a qual é uma mensagem
inspirada por Deus, a fim de encorajar ou admoestar o suplicante; ou ele
pode receber uma palavra de conhecimento que é uma intuição de origem
divina sobre a situação do suplicante que não poderia ser conhecida por
meios naturais. O curador é praticamente o único que fala, guiando as
reflexões do suplicante enquanto "faz Jesus passar" pela sua vida
(CSORDAS, 2008, p.35).

Dessa maneira foi realizada a cura de memórias regada por música que se iniciou no parquinho e terminou na capela. No parquinho, pode-se notar movimentos pendulares e abraços. $\mathrm{Na}$ capela pude observar o choro, contração da face e o repouso. Após o momento de cura, fomos todos dormir.

No domingo, às $8 h$ da manhã, as atividades se iniciaram no rincão com o terço. Após o terço se fez um momento de animação muito descontraído, onde todos sorriram muito. Em seguida o momento de oração com músicas do Espírito Santo. Um novo convidado realizou uma pregação. Ao fim da pregação foi avisado que em seguida se daria início a missa, e rezou-se uma Ave-Maria.

A missa aconteceu. Após a missa todos almoçaram, arrumaram as malas, e às quinze horas todos voltaram ao rincão. Lá era realizado um momento voltado para danças, seguida da deles era mais pular ao centro e se deslocar pulando no meio dele. 
oração com músicas ao Espírito Santo. Nesse momento específico de oração, pediu-se para rezar para o irmão do lado e notou-se várias técnicas utilizadas, o abraço, as mãos dadas, imposição de mãos só na cabeça, só no ombro e ainda na cabeça e no ombro. Ao fim da oração o novo pregador foi convidado, e conduziu um momento de oração com ênfase na manifestação dos dons do Espírito Santo, em especial o dom das línguas e do repouso. Ele pediu para não ter medo e dirigiu um discurso, a fim de produzir a predisposição nos fiéis. Após realizar seu discurso, ele começou a cantar uma música, os músicos deram continuidade, eles e os servos circularam em meio aos participantes realizando a imposição de mãos e rezando por eles. O pregador interrompeu a música para ensinar a orar em línguas, ele disse assim "Repete comigo, aba Pai! Aba Pai! Aba Paizinho! Abaladoba. Adabadala. É assim mesmo, continua! Abadolabolalalalelele".

Essa forma de ensinar expondo um conjunto de técnicas, a fim de facilitar a eficácia do contato com o sagrado, lembra-me do ensinamento de Mauss (2003), ao dizer que toda imitação é prestigiosa. "É precisamente nessa noção de prestígio da pessoa que faz um ato ordenado, autorizado, provado em relação ao indivíduo imitador, que se verifica todo o elemento social" (MAUSS, 2003, p. 405). Tudo o que se aprende é imitável e mesmo que seja uma imitação, ela possui reconhecimento social. É exatamente por isso é que se propõe uma imitação de experiências místicas.

Nesse mesmo sentido, pude evidenciar no decorrer dessa oração, que alguns servos exerciam força sobre alguns participantes, de maneira a produzir movimentos pendulares, que podem levar ao participante, o sentimento de torpor e, em seguida, o repouso no Espírito. Mas também pude notar pessoas repousando espontaneamente sem a imposição de mãos ou o abraço. Nesse momento, a metade dos participantes do rincão já havia executado a técnica do repouso.

A oração seguiu com o canto de "Glória", na melodia criada pelo compositor católico Martín Valverde. Ao iniciar o canto da música, cerca de dez pessoas repousaram. Os participantes que se encontravam de pé levantaram suas mãos para os céus e seguraram as mãos dos que estavam ao seu lado. Eles cantavam a música com toda a força de seus pulmões e se embalavam de maneira quase que sincronizada ao canto produzido. Foi bonito de se ver essa cena, todos unidos, se embalando pela música e cantando para Deus. Ao final, pediu para desenhar o sinal da cruz na testa de um irmão. Na religião Católica Romana,

Foi a Renovação Carismática que recordou à Igreja a necessidade e a importância da oração de louvor. Quando se fala de louvor na Igreja, vêm à mente os carismáticos. Quando falei da oração de louvor, durante uma Missa em Santa Marta, eu disse que não é somente a oração dos carismáticos, mas da Igreja inteira! Trata-se do reconhecimento do senhorio de Deus sobre nós e sobre toda a criação, expressa com a dança, a música e os cânticos (PAPA FRANCISCO, 2014, p.3). 
Portanto, o entendimento do Catolicismo é de que a música e a dança contribuem para reforçar a fé dos fiéis, ao mesmo tempo em que representam um desígnio de Deus.

\subsection{Bailando em comunhão}

Quando perguntei a um entrevistado sobre a relação da dança com a interação social, foi me respondido que é objetivo da animação promover a interação social. "O foco é esse 'né'? Unicamente para despertar o jovem, porque no inicio quando todo mundo chega no grupo, para começar a atividade do grupo, se percebe que 'tá' todo mundo calado, um não olha para a cara do outro, 'tá' todo mundo tímido. Aí começa a fazer a atividade da animação, aí percebe-se que todo mundo começa a ficar mais animado, já dá o sorriso no cantinho da boca, um olha para o outro. Já tem mais um afeto, um carinho maior com o outro, [...] então acaba que a pessoa se torna mais afetuosa. E a dança e a atividade alí faz com o que isso aconteça 'né'? A interatividade acaba acontecendo, não tem como não dizer que não há a atividade e a interatividade, uma coisa 'tá' ligada com a outra" (E5).

Essa ideia segundo a qual a ação em si gera uma interação social também foi relatado por Machado de Vargas (2007). Para a autora, a dança sempre foi um elemento integrador da comunicação pessoal e coletiva, das manifestações de sentimentos, facilitando as relações sociais.

Para Durkheim (2009), o homem que cumpre seu dever encontra nos momentos que exprime simpatia, estima e afeição aos seus semelhantes, uma impressão de reconforto, da qual muitas vezes não se dá conta mas que o sustenta na religião. De modo que as danças, podem ser vistas como essenciais para a integração de jovens na religião através das danças.

Assim como observado no show de louvor e nas danças coreografadas, ${ }^{46}$ a comoção, a onda de efervescência, que faz com que uns contagiem o outro na amplitude e na dedicação fervorosa ao movimento. "Sob a influência de uma grande comoção coletiva, as interações sociais tornam-se mais frequentes e ativas. Os indivíduos se procuram, se reúnem mais. Disso resulta uma efervescência geral, característica das épocas revolucionárias ou criativas" (DURKHEIM, 2009, p. 216).

O Ágape também apresenta outros fatores que contribuem para que a dança seja vista como um elemento integrador das relações sociais. Muitas vezes, as danças são interrompidas para que se converse com outra pessoa. Em outras vezes ainda, o diálogo continua quando o animador pede que se façam duplas e então a música é cantada de um para outro com sons e gestos.

\footnotetext{
${ }^{46}$ Foi no retiro que a comoção durante as danças coreografadas se fez mais explícita.
} 
Outro fator que interrompe as danças é a oração. Muitas vezes termina-se uma música mais cedo para realizar uma oração, que normalmente é a de louvor. As danças, no Ágape, coreografadas ou livres, sempre são realizadas em meio a orações e/ou reflexões que conduzem o pensamento a Deus. Fato que a torna sagrada, pois como já dito, na mente das pessoas, o sagrado não entra em contato com o profano. Ou nas palavras do participante "quando você une a dança com o momento de oração, eu não entendo que ela é profana a palavra de Deus, que é uma coisa errada 'né'?” (E4). De forma que uma música, quase sempre após cantada e coreografada pelo participante gera um momento de louvor e como já dito, muitas das vezes é difícil separar o momento de animação com o de oração nos encontros do Ágape.

Em algumas obras que abordam a presença da dança dentro de denominações cristãs como a de Coimbra (2003) e Telles (2015), a dança é tratada como ação de louvor e/ou de adoração. Coimbra (2003) relata que Deus tem usado a dança para sua hora e glória, derramando coreografias preestabelecidas por ele e que os fiéis devem tomar posse daquilo que é de Deus a fim de desenvolvê-la no louvor e adoração. Ela ainda acrescenta que Deus derrama bênçãos no louvor e na adoração, pois é através destes momentos que se experimenta a comunhão e uma intimidade com Deus.

A dança, para Garaudy (1980), tem a capacidade de tornar o Deus presente e o homem potente, pois ela revela que o sagrado também é carnal, é uma forma de externar o que se encontra dentro do homem. Ou ainda, segundo Lara (2000a), a dança retoma a possibilidade de comunicação com o divino.

Paulo me relatou que há um tempo atrás um rapaz foi ao grupo e a animação foi feita com uma musica que fala de marchar para o senhor, de ser do exercito de Deus, segundo o coordenador, algo comum de se fazer. Então ele escolheu casualmente um rapaz e falou pra ele "olha você agora vai na frente conduzindo esse exército", convidando-o para que ele dance na frente de todos. Ao final do encontro o rapaz procurou o coordenador e disse que pra ele aquela postura de ir a frente foi uma comunicação profunda com o divino. Nas palavras do coordenador "foi Deus falando com ele" porque dias antes de ir ao grupo, o rapaz perguntava para o Senhor "o que o senhor quer de mim? O Senhor falava, eu quero que você conduza meu povo”, algo assim, o Altíssimo dizia pra que ele assumisse a missão dele. Foi no grupo de oração, no momento de animação, que Deus conversou com o rapaz e fez com que ele entendesse o que de fato o Senhor queria pra ele. Como já foi dito, para Eliade (2008) uma das características do sagrado é que ele se manifesta. Nesse caso, se manifestou através da dança.

Outro fator que mostra a dança coreografada como sagrada é o fato de se mostrar como uma fuga da sociedade laica, cotidiana e ordinária. Portanto, por conta da fuga, para Rodrigues (1983), pode ser reconhecida como sagrada. Fato que pode ser comprovado como tal pela seguinte fala: "Eu não vou em festas, nesses negócios aí, mundanos aí. Então aqui é um jeito de eu me 
divertir, buscando a Deus, profetizando a Deus, então eu prefiro me soltar profetizando a Deus do que... entendeu? Igual, muitas festas, muitas coisas do mundo aí, hoje em dia, entendeu?" (E1).

A ludicidade, de acordo com Lara (1999b), é considerada profana, mas ao passo que se busca a ludicidade de maneira não laica, buscando a transcendência, ou profetizando a Deus, a dança reflete elementos sagrados.

Outro fato que faz com que a dança seja considerada sagrada, de acordo com Rodrigues (1983) é ela ser formada por um modo de proceder que inclui o respeito e o temor que tradicionalmente são requeridos. Para o entrevistado 2, pelas coreografias, dá pra se identificar se o modo de proceder inclui respeito e temor e ainda acrescenta "em uma dança sagrada, você não vê a menina descendo até o chão e empinando a "bundinha'” (E2). Tal fala vem reforçar o que já foi dito, que o chão e os elementos da parte inferior do corpo são vistos como elementos profanos. Outro entrevistado ainda faz referência ao modo de proceder. "Tem a postura e tem movimentos que a gente tem que se vigiar para fazer, acho que não dá 'né'? Ainda mais música da Igreja e do grupo de oração, acho que a gente acaba vigiando o nosso corpo no sentido de movimentos 'né'? O que fazer, o que não fazer, o que pode, o que não pode" (E3).

O fazer e não fazer, o que pode e o que não pode na Igreja e em um grupo de oração divide o mundo em dois domínios, um é o sagrado e o outro o profano. Eles são em toda parte concebidos como gêneros separados dois mundos que nada têm em comum. O homem é exortado a retirar-se totalmente do profano, a fim de levar uma vida religiosa.

"Quando o momento e o lugar são sacralizados, o corpo encarna sentimentos subliminares e expressa intenções e pensamentos dos inconscientes individual e coletivo" (LARA, 1999a, p.111). A dança entre os carismáticos apresenta um misto de individualidade e coletividade, de sagrado e profano, percebidas nas diferentes formas coreográficas.

Visualizar a dança como sagrada e/ou profana foi possível e perceptível ao modo concebido por Lara (1999a), em seu contexto geral tomando como fatores os dançarinos, música, coreografia, gestualidade, tempo e espaço. Contudo, quanto ao ser dançante, só foi possível realizar a análise pela condição sagrada e/ou profana quando a ocorrência da transcendência me foi relatada por Paulo. De acordo com Lara (1999a), nesses casos particulares a relação entre as dualidades tende a ser mais flexível, pois cada pessoa tem as suas particularidades de ingresso ou não no mundo mítico.

\subsection{Danças livres}

Por mais que a música não seja necessária para o dançar; o som, o ritmo, a melodia e a letra oferecem um momento propício para ela. No Ágape, a música se mostra presente e até mesmo 
parece ser necessária em várias ocasiões. Em meio a estes momentos musicais, observa-se técnicas corporais, aqui amparada por Saraiva et al. (2005) e Coimbra (2003), denomino danças livres.

A dança na liturgia cristã é normalmente vista sob duas perspectivas: as danças coreografadas, as quais serão abordadas na seção seguinte, e a dança livre. Para a autora, a primeira se assemelha à música, pois acompanha as letras; já a segunda se assemelha a uma melodia espiritual, sendo algo que brota espontaneamente do coração. $O$ fato é que, nas danças livres, o desejo de louvar e adorar são a tônica e a razão pela qual os movimentos fluem.

A dança, para Saraiva et al.(2005), como já dito, possui seus elementos constitutivos, são eles música, ritmo, técnica, dialética de movimento e o espaço físico. Ao abordar estes elementos, os autores enfocam que o mais importante é a dialética do movimento, de forma que os outros se tornam elementos motivadores e até certo ponto supérfluos. Para eles, o importante é que haja fluidez no movimento e que eles aflorem das particularidades da pessoa, numa percepção que transcende a de que a dança é uma expressão meramente utilitária. De forma que as técnicas utilizadas para realizar os movimentos podem ser as típicas das danças ou técnicas presentes no cotidiano, o importante é o significado do movimento na fluidez emanada pelo corpo.

Ou seja, as danças livres são os movimentos corporais que emanam dos momentos de introspecção, como de oração e/ou reflexão, e no período de exaltação, como no show de louvor.

As danças introspectivas identificadas foram os movimentos pendulares laterais ou frontais realizados de mãos dadas ou não. Ao realizar essas oscilações, que asseguram a ideia de fluxo de movimento, muitos realizaram outras técnicas como levantar as mãos, balançar as mãos ao alto; pôr a mão no peito; abrir os braços, sugerindo uma posição do corpo em forma de cruz; contrair músculos faciais; segurar na mão da pessoa ao lado; ou até mesmo, chorar.

Ao perguntar a uma participante o que significavam os movimentos pendulares, foi me dada a seguinte resposta: "Sintonia, conexão, a pessoa está conectada a uma coisa muito maior do que ela quando ela 'tá' assim. Porque é isso que eu sinto entendeu? É muito maior, ela 'tá' por exemplo, no meio da oração 'né'? E ela está conectada ao espiritual dela, lá dentro, porque assim, eu imagino que Deus, ele não 'tá' lá longe, ele 'tá' aqui comigo 'né'? Aqui dentro de mim, então ele 'tá' em plena sintonia" (E9).

Assim, como sugere a fala da entrevistada, a dança realizada por meio de um conjunto de técnicas corporais, inspiradas por um movimentar-se, ao serem realizadas como forma de oração possui - além do significado da dança em si, como um complexo movimento corporal - um significado de vinculação com Deus, mediado pela corporeidade de cada participante. 
Os movimentos pendulares, tais quais descritos pela participante "buscam o abandono momentâneo do tempo profano para a vivência do tempo sagrado, da entrega, do encontro, da relação com o 'eu' e com a interioridade manifesta" (LARA, 1999b, p. 54).

Para os carismáticos, essas danças realizadas livremente e por meio de movimentos pendulares refletem a conexão com o Divino. O homem religioso, de acordo com Eliade (2008), tem a necessidade de inteirar-se da realidade divina e, nas religiões mais desenvolvidas, ele acaba por encontrar em si mesmo a santidade. Não só os assim chamados rituais recebem uma significação sagrada, mas até gestos aparentemente sem importância recebem significado harmônico com o Ser sagrado.

Além da conformação da dança introspectiva, o grupo utilizou-se de outras práticas corporais, que podem ser entendidas também como atividades dançantes ou que se pautam por uma relação entre música, ritmo, técnicas, dialética e espaço, consoante o entendimento de Saraiva et al. (2005). Nesse caso, a atividade do balão, que consistiu numa dinâmica com a finalidade de iniciação dos servos, a fim de que eles refletissem sobre suas histórias de vida, inspirando-se no passado, é um bom exemplo.

No dia 30 de julho, na adoração de iniciação dos servos, após o terço e a animação, os coordenadores do grupo explicaram a atividade a ser realizada e seu objetivo. Os participantes, servos iniciantes, que naquele dia eram em torno de 20 pessoas, dentre oito homens e doze mulheres, pegaram os balões, que eram todos de cor amarela. Antes de enchê-lo Bárbara perguntou quem lembrava da primeira vez que começou a servir e disse que de lá pra cá aconteceram muitas coisas. Disse que podia encher o balão, mas era pra enchê-lo colocando todas as intenções, os sentimentos, todos os detalhes da época, colocando toda a história dentro dele. Após verificar que os balões estavam cheios, ela pediu para olhar para o balão cheio e não tirar os olhos da história que se colocou dentro dele. Bárbara explicou que essa era uma dinâmica, todos deveriam andar pela capela olhando para o balão, olhando para sua história, relembrar tudo e entregar a história para Deus.

Cantou-se a música "A Barca" ${ }^{47}$, enquanto andavam de um lado para o outro. Era um caminhar lento, no ritmo que a música propõe. Quando atingiam o limite da extremidade da capela, realizavam giros lentos e melancólicos. Movimentos mais bruscos eram realizados somente quando uma pessoa avistava que outra estaria muito próxima, ainda assim, alguns esbarrões se mostravam inevitáveis, vez que centravam os olhares mais no balão e orientavam seus deslocamentos na melancólica cadência da música. Em meio à canção, Bárbara, disse palavras bonitas em relação a

\footnotetext{
${ }^{47} \mathrm{~A}$ música possui as seguintes palavras: Tu te abeiraste na praia. Não buscasses nem sábios, nem ricos. Somente queres que eu te siga. Senhor, Tu me olhaste nos olhos. A sorrir, pronunciastes meu nome. Lá na praia, eu deixei o meu barco. Junto a Ti, buscarei outro mar. Tu sabes bem que em meu barco. Eu não tenho espadas nem ouro. Somente redes e o meu trabalho. Senhor, Tu me olhastes nos olhos. A sorrir, pronunciastes meu nome. Lá na praia, eu larguei o meu barco. Junto a Ti, buscarei outro mar.
} 
Deus chamar para servir, incentivou a lembrar do passado oferecendo detalhes como: pessoas, tempo, lugar e incentivou que todos entregassem cada detalhe.

Depois de um tempo, Bárbara pediu para brincar com o balão. Com a brincadeira deu-se início uma música mais acelerada, "Celebra a Vitória" ${ }^{48}$, e seguiu-se um padrão semelhante a música anterior, Paulo cantando e tocando a música ao fundo, enquanto Bárbara conduzia a reflexão e todos andavam de um lado para o outro, dando tapinhas nos balóes, afim que eles flutuassem para cima. Os tapas nos balões não eram agressivos, refletiam também o ritmo que a música propunha, um pouco mais acelerada que a anterior, mas não ao ponto de impor muita velocidade ao balão em movimento. Os esbarrões se mostraram menos frequentes e os giros mais entusiásticos. Ainda assim, às vezes, alguns movimentos fora do ritmo eram percebidos, quando o objeto parecia sair de controle de quem estava conduzindo.

Nesse meio tempo, Cláudia disse algo a algumas pessoas, que passaram a agir de forma diferente, como tentar tomar o balão do outro, ficar quieto só olhando no balão, estourá-lo ou trocá-lo com outra pessoa. Ao tentar tomar o balão, os primeiros gestos se mostraram afinados com a música, no entanto, a fim de alcançar o objetivo da dinâmica, Vitor agiu com mais euforia. Os que foram escolhidos para ficar parados, ainda que em um espaço mais delimitado, se mostravam embalados pela musicalidade, ao realizar movimentos pendulares. Foi interessante notar que os que estouraram seus balões, se demonstraram perdidos, em meio à dinâmica, de modo que ao perder o balão, se mantiveram estáticos e observadores das práticas alheias. Ao receber um novo balão, eles se recompunham em movimentos ritmados pela música.

Ao fim, Bárbara disse que o momento estava acabando e perguntou: "como você chegou até aqui?". Disse ainda que Deus nos chamava a ser santos e pedia para cantar a música "Sede Santos" ${ }^{\prime 9}$, todos cantaram e com o balão nas mãos realizaram algumas técnicas corporais como os movimentos pendulares laterais ou frontais, o agitar de mãos brusco e intermitente, alguns contraíram músculos faciais gerando uma careta e destes, alguns choraram.

\footnotetext{
${ }^{48} \mathrm{~A}$ letra dessa música é: Vê! Quem te elegeu, te ungiu e consagrou. Não temas! Nos lábios santos teu nome ressoou. Não te chamou como um servo qualquer, Mas com carinho, um filho seu. Capacitou-te, toda força te deu, amparou e acolheu. Ergue-te, pois, Deus te fez um vencedor. Celebra a vitória! O Senhor Jesus regressando está! Vitória! Canta com unção tua vida! Crê! O tempo é curto e não dá pra esperar. Tu não vês? O tentador só procura te enganar. Dizendo que tens mil motivos enfim para tudo abandonar, abraça o que é teu, permanece fiel, luta sem desanimar. Erguete, pois, Deus te fez um vencedor! Celebra a vitória! O Senhor Jesus regressando está! Vitória! Canta com unção tua vida!

${ }^{49}$ Sua letra é: Deus consagrou um povo escolhido, o amou profundamente desde toda a eternidade. Para ser sal e luz, gerar Cristo Jesus no seio da humanidade. Hoje este povo tão amado, Deus nos chama a viver o seu amor. Convida-nos a todo instante sem cessar e pede para nós: sede santos. Sede santos esta é minha vontade, sede santos é o que eu mais quero. Vou ser santo, esta é minha resposta, vou ser santo, eu digo sim, Senhor.
} 
Bárbara pediu para todos irem para seus lugares, olhar para Jesus (todos dirigiram o olhar para o sacrário) e entregarem sua história, começaram os ecos de vozes destoantes, o balburdio, gerado pelas falas individuais. Notou-se que Paulo, que estava cantando e tocando o violão (que ajudou a presidir todo esse momento junto com Cláudia e Barbara), iniciou a oração em línguas. Bárbara tentou dar continuidade à oração, apresentando detalhes, notou-se que muitos orientaram suas orações, a partir dos detalhes que foram apresentados. Quando o eco de vozes destoantes cessou, Paulo voltou à canção anterior que foi cantada muitas vezes nesse momento de reflexão e do início ao fim realizou-se os movimentos pendulares.

Cláudia relatou a experiência que tivera, disse que a cruz refletida no balão significara muito pra ela, (ele) que pode ver Cristo em sua história (na história dela). Outras pessoas falaram, um chorou descrevendo a experiência. Percebeu-se que cada um deu um significado diferente para o balão. Ao final da descrição, fizemos uma grande roda, cantamos novamente, agora uma música que dizia que Deus faz tudo novo, e estouramos o balão.

Durante a dinâmica com os balões, as técnicas corporais empregadas foram: segurar o balão enquanto caminhavam, dar tapas leves nos balões a fim de mantê-los flutuando no ar, movimentos pendulares laterais ou frontais, o agitar de mãos brusco e intermitente, contrair músculos faciais e o choro. Interessante notar, durante a dinâmica, os vários significados incorporados ao balão: não se segurava um mero balão, mas aspectos da vida de cada indivíduo, e que estavam sendo ali representados.

Por possuir aspectos do cotidiano, a dinâmica sugerida pode ser entendida da mesma forma que Eliade (2008) interpreta aspectos do cotidiano associados à significação profana. Dessa maneira é visto tanto $o$ ato de caminhar, quanto a história materializada pelo balão. Já ao possuir aspectos voltados para a interioridade e que conduzem a relação com o ser mítico, segundo Lara (1999a), a vivência aponta para o sagrado. A interioridade pode ser percebida no momento de olhar para dentro da história e a relação com o mítico ao se refletir sobre a mesma entregando-a ao ser desconhecido, sendo que tudo isso se faz caminhando.

O momento de retomar o passado, relembrando aspectos históricos e propor o recomeço de uma vida renovada em energia, como o fato de estourar o balão dando início a uma nova vida, para Eliade (2008), reflete o sentido de sagrado. A vivência do sagrado foi realizada com deslocamentos na extensão da capela ao som da música. Houve uma proposta de desapego da história profana e incorporação da história divina com a tentativa de fazer o balão flutuar. Quando definitivamente estoura o balão e canta-se repetidamente a parte da música que diz "vou ser santo, essa é minha vontade, eu digo sim, Senhor" o sagrado se apodera das pessoas, manifestado pelas diversas técnicas corporais de empoderamento. 
Pode-se notar o quão afinado com a música é o ato de caminhar pela capela, assim como dar tapas no balão, para que este reproduza a cadência da música, refletem aspectos do sagrado e do profano atrelados às histórias de vida. De forma que a caminhada profana da vida cotidiana acaba por ser reproduzida e ressignificada ao marchar pela capela, um lugar sagrado, ao ritmo de uma música de inspiração divina. Assim, a vida de um ser profano se sacraliza, por conta da nova vivência histórica, do lugar e da música.

O lugar e a música podem ser vistas como sagradas pelo mesmo aspecto proposto por Eliade (2008), a irrupção do sagrado. No caso da capela, ela é o espaço onde guarda o pão sagrado, conhecido pelos católicos como o corpo de Cristo. No caso das músicas religiosas, elas também se mostram como qualitativamente diferentes por guardar palavras sagradas e proferir o nome de Deus em suas letras. De modo que os gestos mais simples e cotidianos se encaixados em músicas sagradas, com o mesmo sentido, de guardar as palavras sagradas e transmitir Deus, elas podem ser definidas pela mesma categoria.

Outro momento repleto de músicas sacras que também pode ser entendido como um momento de danças livres foi o show de louvor ministrado pelo padre. Pude identificar durante o louvor um conjunto de técnicas corporais empreendidas por cada participante, que acompanhavam os movimentos corporais do padre. São elas: palmas em cruz; chutes na diagonal; a roda de hardcore e a dinâmica do trenzinho, como momentos de exaltação. Tais técnicas refletem a tensão entre o sagrado e o profano, por se constituírem um importante momento de socialização entre os participantes.

O que define a dança como um ato profano, segundo Bejárt (1980), é o fato de explicitar a interação com os outros. Muitas dessas técnicas foram realizadas em conjunto, combinado para que lado iriam as palmas e os chutes. A roda de hardcore e o chute, além de apontarem para um aspecto mais interativo que divino, aparentaram como o cume da ludicidade de todas as danças observadas nessa pesquisa. Consegue-se dimensionar aqui que essas práticas corporais também ensejam uma espécie de terapia em grupo, ao passo que estimulam, além da socialização dos participantes, o extravasamento de suas emoções.

Quanto ao caráter lúdico da prática em análise - show de louvor - percebeu-se no caso que se trata de uma prática que busca em pequeno grau o sagrado, engendrando uma dinâmica mais descontraída e mais voltada para a interação social, ou algo profano. Nele, a interação com os outros se manifesta, ocasionando o afastamento do sagrado. Leva a momentos de agitação a tranquilidade, de distração a calmaria, em que preocupações e trabalhos são esquecidos (LARA, 1999b).

Por outro lado, o sagrado ocorre pelo extravasar das emoções (SOFIATI, 2009). O show de louvor foi um momento onde ação estimulante da sociedade se fez sentir. Os sentimentos agitam as 
pessoas de tal forma que acabam se materializando em atos eufóricos e coletivos, tais quais entendidos por Durkheim (2009, p. 222):

Uma vez unidos, os indivíduos, sua aproximação libera uma espécie de
eletricidade que os transporta rapidamente a um grau extraordinário de
exaltação. Cada sentimento expresso vem repercutir, sem resistência, em
todas essas consciências largamente abertas às impressões exteriores:
cada uma delas ecoa as outras e reciprocamente. O impulso inicial vai
assim se amplificando à medida que repercute, como uma avalanche
aumenta à medida que avança. E como as paixões tão intensas e tão
liberadas de todo controle não podem deixar de extravasar, o que se vê, de
todos os lados são gestos violentos, gritos, verdadeiros urros, ruídos
ensurdecedores, que contribuem para intensificar ainda mais o estado que
manifestam. É claro que, como um sentimento coletivo só pode se exprimir
se observar uma certa ordem que permita a coordenação de gestos e esses
gritos tendem naturalmente a ritmar-se a regularizar-se; daí, os cantos e as
danças.

É por conta da comoção social, a onda de efervescência de sentimentos transmitidos individualmente mas reafirmados e influenciados coletivamente que a interação social torna-se sagrada. Pois é através da vivência coletiva que a sociedade se faz sentir.

A alegria é algo incomparável na presença de Deus, de acordo com Coimbra (2003), pois fomos criados para celebrar o louvor ao Deus de nossa vida, o nosso Salvador. A dança em um momento de louvor não é uma prática corporal por ela mesma. Ela é parte integrante do louvor. "Nela, a essência de total entrega do adorador se manifesta por uma espontaneidade responsiva, trazendo toda a congregação para momentos de júbilo, libertação e restauração da presença de Deus" (COIMBRA, 2003, p.73).

Em uma entrevista com uma das participantes, perguntei se ela conseguiu sentir Deus no momento do show. Ela me respondeu da seguinte maneira: "Toda vez que eu danço eu fico cheia do Espírito Santo. Coloca a música do Espírito Santo, a gente começa a dançar. Nossa! Toda vez que eu danço, eu fico toda mais animada, eu sou suspeita porque eu adoro dançar" (E8). Então eu perguntei como ela sabe que está cheia do Espírito Santo. E eis que ela assim me respondeu: "Então, eu fico mais alegre, mais animada. Fico rindo à toa" (E8). Outra participante ainda afirma que a dança serve como expressão de sentimentos dentro da Igreja, "é uma forma expressar nossa alegria então, a presença de Deus" (E6).

As respostas das participantes vêm a confirmar o raciocínio proferido a respeito do contato que é realizado com o sagrado na onda de efervescência de sentimentos que se desenvolve em uma relação contínua entre as pessoas e acaba por ser nomeada pela participante de Espírito Santo. $O$ sentimento de alegria, de acordo com o CATECISMO DA IGREJA CATÓLICA (2003), é um produto do Espírito Santo. Quando durante um show, que os carismáticos cantam músicas de Deus, param às vezes para proferir oração de louvor, e o sentimento coletivo vai se intensificando, eles interpretam 
que o autor principal de suas ações é a divindade e por isso as danças dos shows podem ser consideradas sagradas.

Como não poderia deixar de ser, encontra-se no show uma tensão entre o profano e o sagrado. Profana por se tratar de um momento não reflexivo, com foco na interação e na ludicidade; sagrada, pois a ludicidade gera um sentimento de alegria que é afirmado coletivamente em um momento de êxtase ou efervescência, ou nas palavras deles, pela ação do Espírito Santo.

Há ainda outros dois momentos de danças livres, que não foram visualizadas por mim, mas vieram ao meu conhecimento através de relatos na entrevista e segundo as próprias entrevistadas foram danças que aconteceram em momentos de adoração

O primeiro fato me foi relatado por Bárbara: "Muitas vezes pessoas tem formas diferentes de rezar, de fazer sua oração chegar até Deus. Então, tem gente que se sente melhor rezar dançando do que parado. Então já teve caso no, no momento de adoração do grupo. Que uma mulher, ela começou... ela é bailarina 'né'? Então ela levantou... Todo mundo ajoelhado, rezando, tal... Então ela levantou e foi indo 'pro' fundo, assim, pra não atrapalhar ninguém e começou a dançar e aí ela rezava em línguas dançando. Entende? Então eu acho que é a forma que a pessoa tem de fazer a sua oração mesmo. A forma dela era essa e eu acho que os próprios evangélicos tem muito isso de rezar se movimentando mesmo".

O segundo fato, muito semelhante foi relatado por uma participante do Ágape que serve em outros quatro grupos distintos. Perguntei se a serva já havia visto danças profanas na Igreja, ao que me respondeu que sim e que havia sido bem tenso, ela disse o seguinte: "Bom, normalmente assim, a gente... mas assim, como serva 'né'? A gente costuma a chamar a pessoa, pra não falar na frente de todo mundo, dependendo da situação já teve caso até de carregar, foi bem mais complexo. Porque começa e a pessoa perde totalmente o controle mesmo né?" (E7).

Então complementei a pergunta: houve possessão? E descreveu: "Aí normalmente assim, tem casos que não, mas é mais propício quando coloca o Santíssimo exposto. Então assim, tem pessoas... Não é um momento tão de animação igual antes da pregação normal, mas tem música, então através da música, a pessoa começa de forma lenta e tal, mas aí começa a manifestação. Eu vejo muita contaminação. Eu que fico muito em ministério de intercessão nesses retiros, a maioria que a gente conversou, já envolveu com o espiritismo, então você começa a conversar, você entende de onde vem 'né'?" (E7).

Perguntei onde havia ocorrido o episódio. Ela confirmou que havia ocorrido durante um retiro, mas que também houve caso de acontecer durante o grupo: “... a gente até fez um momento de clamor, nesse sentido, invocando todos os anjos pra renunciar mesmo todo o tipo de manifestação que a gente falou que não queria porque isso causa muito medo, dispersa muito. Então assim, o 
inimigo, ele é muito astuto, ele tenta assim tirar a atenção dos outros no momento que Deus 'tá' ali reinando na nossa frente, 'né'? Outra questão que eu aprendi foi justamente isso também, não voltar o foco, você continua o foco em Deus, por isso também a gente acaba que tendo que retirar a pessoa do local, porque os outros perdem o momento da cura, o momento de adoração, por conta desse tipo de situação. Então é bem delicado mesmo, 'né'?" (E7).

Os dois fatos possuem características em comum, no entanto agregam significações distintas. As duas danças ocorreram em um lugar sagrado, marcado pela presença de Deus, e foram provocadas pelo mesmo fato. $O$ que difere qualitativamente a primeira da segunda está na interpretação que é dada à dança.

Os carismáticos possuem maior afinidade de técnicas e significados de práticas com os evangélicos do que com os espíritas. Carranza (1998) relata que no momento de sua criação, o MRCC se encontrava em contato com participantes do pentecostalismo evangélico. Já os espíritas, como apontam os achados de pesquisa de Rumstain (2007), não compartilham dos mesmos preceitos que os cristãos (sejam eles católicos ou evangélicos).

O discernimento deve ter sido feito pela característica básica do sagrado que, para Rodrigues (1983), é opor-se ao profano. Para o autor, ambos são a maneira de ser a coisa, ou ainda, duas modalidades de ser-no-mundo. O sagrado está permanentemente protegido do contato pelas interdições que o isolam do profano. Tudo o que é sagrado, na mente dos indivíduos, não pode ser colocado em pé de igualdade com o que é profano e muito menos estar com ele misturado.

Telles (2015) relata que muitos atos de adoração e louvor presentes na bíblia chocaram as pessoas, fazendo com que os que observaram a manifestação buscassem explicações de cunho pessoal para o ato, ao tempo em que o questionavam. Ora, a Igreja Católica Romana já condenou pessoas, que hoje são consideradas santas por conta dos estados de alma que a dominavam, especialmente Santa Tereza D’Avila (BORGES, 2005).

Nem sempre a dança considerada sagrada e/ou profana irá coincidir com as formas de vivenciá-la pela pessoa dançante. Entende-se que as danças podem levar à manifestação do sagrado e à transcendência e não que todas levem a tal vivência. Ela pode manifestar o seu caráter sagrado, mas é preciso "deixar acontecer". Caso contrário, tal manifestação dar-se-á, talvez, apenas no nível inconsciente. Embora as situações busquem tempos e espaços diferenciados, assim como o sagrado, uma diferença determinante é a busca pela transcendência, uma vez que o profano não a busca, a sua procura indica o ingresso no mundo sagrado (LARA, 1999b).

Nas danças livres, observou-se que os passos, os encadeamentos, não obedecem a uma ordem pré-fabricada, e dessa forma se aproxima da proposta que Garaudy (1980) chama de dança moderna. A dança revela que o sagrado também é carnal e que o corpo pode ensinar o que um 
espírito desencarnado não conhece: a beleza e a grandeza do movimento de uma pessoa que não está separada de si mesma, mas inteiramente presente no que faz.

\subsection{Danças coreografadas}

Ela existe de modo a facilitar a dança no corpo e torná-lo ainda mais dançante. As danças no MRCC, para Maués (2007), são praticadas quando dos cânticos, durante as mais variadas reuniões, inclusive como coreografia, que se realiza em acompanhamento a esses mesmos cânticos. As danças que serão relatadas aqui aconteceram em pelo menos uma das três atividades observadas, iniciação dos servos, encontro do sábado à noite ou no IV encontro Ágape. As coreografias são, de acordo com Machado de Vargas (2007), um conjunto de técnicas organizadas.

As coreografias geralmente são ligadas entre si, com os momentos que a antecedem e a sucedem com falas dirigidas a Deus ou a outras pessoas. Nos momentos que a antecedem, há a interação pelo menos com o animador, entre as músicas muitas vezes se pede para louvar a Deus ou dizer algo ao irmão de acordo com o tema que a música propõe. Quando finaliza uma animação sempre há o momento de oração em línguas, mesmo que breve.

Eu identifiquei dezenove tipos diferentes de coreografias que se encontram em Anexo (VI) nesse trabalho. São elas, a) Catira pra louvar, b) Consagração à Nossa Senhora, c) Dança da amizade, d) Ele vem, e) Eu sou feliz, f) Hoje é tempo de louvar a Deus, g) Homens de fé, h) Já chegou, i) Na onda, j) O Senhor é rei, k) Passa fogo, I) Quero louvar-te, m) Templo vivo, n) Tum-tumtum de Deus, o) Vai sacudir, p) Vamos cantar, q) Vira de Jesus, r)Vitória no deserto e s) Vontade de louvar. Coreografias estas que têm ritmo próprio, mas que muitas das vezes são repetidas em cadências diferentes.

A música dentro do catolicismo carismático, para Silveira (2004), segue novos padrões, mais ritmados, cadenciados como o rock, pagode e samba. Eu pude identificar estilos que se aproximam do rock pesado como "O senhor é rei", reggae como "Tum-tum-tum de Deus", axé como o "Na onda", conforme os próprios nomes já anunciam os ritmos, a "Catira pra louvar" e o "Vira de Jesus". Em uma das vezes aconteceu de um servo em meio aos participantes fazer um gesto muito empregado por pessoas que dançam sertanejo, como abaixar a cabeça inclinando-a levemente para um dos lados, colocar a mão em punho na testa, o outro punho fechado abaixo do umbigo e realizar um rebolado lento e breve. O guitarrista ao ver esse gesto transformou a música em um arrocha cristão.

Os ritmos variados acabam por incentivar uma variabilidade de técnicas corporais. Exemplo disso é fazer "dois pra lá e dois pra cá" quando uma música tem o ritmo de sertanejo, realizar saltitos 
levantando um dos joelhos como se faz no reggae, bater firmemente os pés no chão, como é o caso da catira, ou ainda realizar deslocamentos regados por pulos, como é no caso do axé e do rock.

Rumstain (2007), ao desenvolver sua pesquisa em uma danceteria cristã, identifica-músicas que tematizam a bondade de Deus, as batalhas entre o bem e o mal, a vitória dos fiéis cantada nos mais variados ritmos. Segundo a autora, canta-se samba, axé ou rock acompanhados de muita dança, com coreografia muito semelhante ao dos não-cristãos, mas desde que a música exalte a Deus, o ritmo se apresenta como insignificante.

No entanto, ainda que haja um ritmo variado e uma variabilidade de técnicas corporais, nota-se um padrão de técnicas nas danças realizadas pelos carismáticos. As coreografias são geralmente realizadas em pé, em meio às cadeiras e estando todos de frente para o animador. Os gestos são realizados predominantemente com a parte superior do corpo, em detrimento da parte inferior.

A parte superior do corpo, especialmente os braços e a mão, possuem a primazia. Os gestos mais executados foram bater palmas e levantar os braços para o alto. As palmas foram realizadas de várias formas, desde próximas ao chão acima da cabeça e nas laterais. Ao levantar os braços ao alto, o movimento poderia ser feito pela elevação frontal ou lateral, com a finalidade de só levantá-los a fim de realizar movimentos da cabeça para cima. Demais gestos com as mãos e braços, são realizados predominantemente a frente do umbigo ou do coração.

A parte superior do corpo se refere a parte mais sagrada (HERTZ, 1980), por isso é a mais utilizada. O umbigo e o coração também refletem a noção do sagrado, pois para Eliade (2008), esses lugares foram eleitos como centrais no corpo humano, sendo o centro o lugar do sagrado.

Quanto à parte inferior, ela se mostra necessária para dar movimento ao corpo, como realizar saltos, pêndulos laterais e os variados deslocamentos. Chutar na diagonal, sacudir uma das pernas a frente, deslizar as mãos na extensão de uma ou das duas coxas de baixo para cima, elevar um dos joelhos a frente, e tocar as laterais dos quadris e os joelhos são movimentos raros no cotidiano dançante de um católico carismático. O quadril, parte que sustenta elementos característicos do sexo de uma pessoa, é a parte mais ofuscada, normalmente se movimenta o quadril de um lado ao outro quando a palavra que se fala na música é "dança".

A parte inferior do corpo acaba por proporcionar o que Jeudy (2002) denomina mobilidade imóvel. Há movimento produzido pelas pernas o tempo todo e é justamente a repetição estereotipada dos mesmos gestos que dão a impressão de imobilidade "como se o movimento voltasse sobre si mesmo para aproximar a impavidez do qual ele nasceu" (JEUDY, 2002, p. 66). Além do mais, os movimentos realizados pelos membros superiores acentuam a impressão de imobilidade dos membros inferiores. 
Cada gesto é realizado de acordo com alguma parte da música, como visto na coreografia de consagração à Nossa Senhora. A dança é coreografada em sua grande parte pelo que Garaudy (1980) chama de mímicas. Compõe-se de movimentos representativos de uma palavra, de uma realidade já existente. São gestos descritivos, que narram as palavras da história que está sendo cantada, como uma duplicação da literatura. Os movimentos realizados durante a dança, quase sempre permitem adivinhar a palavra a qual ele se refere.

Tal forma de dança pode ser vista também como performativa, segundo Tambiah (1985); Ferreira (2009). Há a repetição e encenação, de forma que a expressividade acontece em uma multiplicidade de meios de comunicação, implicando em diversas modalidades sensoriais (ouvir, falar e gesticular). Dessa maneira, as pessoas vivem de modo intenso e com grande impacto o que está sendo anunciado (FERREIRA, 2009).

Com efeito, retomo o que já foi dito a respeito das técnicas corporais de Mauss (2003), para quem toda imitação é prestigiosa. Por mais que pareça imitação gestual das palavras, as técnicas asseguram ao dançarino maior eficácia na apreensão daquelas palavras. Demonstra eficácia até mesmo na comunicação com o divino. Um entrevistado dirigiu a mim a seguinte fala: "Se você gesticula que 'tá' louvando ao senhor, Deus lá de cima, ele te olha, ele te vê. A sua expressão corporal, ela é uma forma de você falar com Deus. Então cada gesto, cada olhar, cada forma de você se expressar, Deus 'tá' vendo. As vezes, por exemplo, tem pessoas que tem dificuldade de chegar de frente do santíssimo e falar o que tem que falar do coração, mas a expressão corporal dela de ficar de joelho e estender a mão diante do santíssimo, eu creio totalmente que Deus 'tá' vendo aquele gesto ali como uma entrega. Acho que se a pessoa tem a facilidade de uma expressão corporal de entrega de expressar pra Deus, Deus reconhece. Eu acho que a dança é uma expressão, uma expressão tão forte que às vezes não precisa de palavras. Só que é uma expressão mais alegre, 'né'? De mais movimento" (E5).

Nesse ponto, a dança se assemelha à glossolalia, pelo fato de ser reproduzida por meio da técnica que faz com que o fiel entre em contato com o sagrado sem proferir uma palavra de sentido humano.

\subsection{Intersubjetividade partilhada pela dança}

Não somos subjetividades isoladas dentro de nossos corpos. De acordo com Csordas (2008), compartilhamos um meio intersubjetivo com os outros. Embora haja corpos sempre presentes, nem sempre dá-se atenção a eles. A atenção aos movimentos corporais dos outros fica mais clara ao realizar técnicas corporais coletivas como dançar. Ao dançar,

Alguns enfatizam a atenção ao corpo e alguns com o corpo; alguns enfatizam a atenção ao próprio corpo, alguns a atenção aos corpos dos 
outros, e alguns a atenção de outros aos nossos corpos. O que eu quero dizer é que as maneiras pelas quais damos atenção aos e com os nossos corpos, e mesmo a possibilidade de dar atenção, não são nem arbitrárias nem biologicamente determinadas, mas são culturalmente construídas (CSORDAS, 2008, p.374).

Os carismáticos apresentam-se ricos quanto à experiência corporal partilhada, inclusive em meio à dança. Tanto que podemos elencar a interação social com e sem o toque. Com o toque percebe-se o "dar as mãos", abraçar, cutucar, unir pela parte medial da articulação do cotovelo a fim de realizar giros. Sem o toque, as interações realizadas através da dança mais recorrentes são o sorriso e o olhar, mas também outras. Às vezes percebe-se uma maior amplitude ou agilidade de movimento em resposta a um olhar ou em proposta de interação, que normalmente é respondida com um sorriso.

As técnicas realizadas por meio da dança são vistas também como um elemento eficaz no sentimento de pertença ao grupo. Pois, à medida que o participante aprende os gestos e assim se assegura da tradição, automaticamente ele se sente em um estado de pertença. Como pode ser percebido na fala a seguir: "Nas primeiras vezes que eu fui no grupo, nossa, eu senti tanta vergonha de dançar. Falava 'gente o que esse povo 'tá' dançando, pulando'. Então, a medida que eu fui frequentando eu fui me sentindo mais livre, mais solta, tipo assim parando de pensar o que o outro vai achar do jeito que eu to dançado e pulando. Por isso eu acho que quanto mais você 'tá entrosado no grupo, mais 'tá' aberto pra aquilo, o seu corpo reflete nisso. O corpo vai se abrindo e começa a ser mais natural, leve e entrando no ritmo mesmo das outras pessoas que estão ao seu redor" (E10).

Em outras palavras, quando ela chegou ao encontro de sábado à noite, ela não sabia que era tradição do Ágape realizar danças. À medida que foi vivenciando, ela passou a se sentir pertencente àquele grupo.

O que também pode ser percebido na fala a seguir, mas com outro sentido. "Às vezes eu fico [pensando] assim, 'será que eu to dançando certo? No ritmo? Será que eu 'tô' fazendo o passo certo? 'Quando eu fico lá na frente falo 'gente se eu fizer alguma coisa errada, todo mundo 'tá' olhando"' (E8). Nesse caso, a técnica se mostra especificamente como um gesto da interação social, apresentada por Goffman (2013). O ator social se encontra preocupado em como expressar a si mesmo e impressionar os observadores. Afinal de contas, ele se encontra em uma cena na qual é ao mesmo tempo observador e observado.

Ao questionar um entrevistado se ele observa o jeito que os outros dançam, ele respondeu: "Isso faz parte da leitura da gente, no dia-a-dia tudo que você faz, você repara. Então se você 'tá' durante um grupo de oração naquele momento de cântico e de dança, se tem alguém no seu lado ou à frente, é claro que você vai reparar. Até mesmo porque você fica curioso pra poder aprender o jeito que a pessoa 'tá' dançando, então sem sombra de duvidas você repara” (E4). 
Um dos elementos que contribuíram para afirmar a presença de olhar o corpo do outro na dança realizada dentro Ágape é que a aprendizagem das técnicas se dá por imitação. Muitas das vezes, não se explica verbalmente como realizar um movimento, mas sim chamando-se uma pessoa à frente que vai realizar um movimento. Então é necessário que se veja para fazer. Quando tem somente o animador cantando à frente, muitas das vezes as pessoas olham para os lados a fim de apreender a técnica do movimento. 


\section{CONSIDERAÇÕES FINAIS}

No presente trabalho eu me propus a compreender o significado da vivência da corporeidade dos jovens do movimento católico carismático, considerando a dança como uma prática corporal que pode possibilitar processos de interação social e a relação com o sagrado. Procurei apontar caminhos para a reflexão sobre a dança religiosa, oferecendo uma leitura a partir da corporeidade dos sujeitos. Digno de notar que a dança promove a interação social entre os participantes e aponta uma clara relação estabelecida entre sagrado e profano. Esses fatos estão ancorados no corpo. Desse modo, foi necessário superar a tradicional dicotomia entre sujeito e objeto, para direcionar uma reflexão que recupere os nexos entre os corpos e a divindade na dinâmica da experiência social vivida por meio da dança.

Evidenciou-se em campo dois tipos de danças nas atividades propostas pelo grupo Ágape. Assim como Coimbra (2003) que percebe a dança cristã na liturgia, o grupo Ágape desenvolveu dois tipos de dança, a dança coreografada e a livre. A primeira está mais relacionada com a música, ou com a letra na qual se acredita que Deus inspira o compositor. A segunda como o próprio nome já diz, é mais livre se assegurando na maioria das vezes como um cântico espiritual e de uma interlocução mais direta com Deus. De forma que ambas possuem no mesmo plano uma abordagem evangelística.

Como danças livres, eu identifiquei os movimentos pendulares (realizados com gestos de braços variados), a dança com o balão que tendeu a reproduzir o ritmo da música que estava ao fundo, palmas em cruz, chutes da diagonal, roda de hardcore, o trenzinho e as danças ocorridas em momentos de adoração.

Nas danças coreografadas, os carismáticos apresentam-se ricos quanto às técnicas corporais utilizadas. Evidenciam as palmas e as técnicas realizadas a cima da cabeça. Já na interação com outros movimentos, as técnicas específicas são "dar as mãos", abraçar, cutucar, unir pela parte medial da articulação do cotovelo a fim de realizar giros, sorriso e o olhar.

As danças se mostram como uma forma de se louvar com o corpo, que requisita da busca pela transcendência e modos de agir e inspiram a fuga do cotidiano, a socialização, a alegria e a afetividade. Em suma, apontam para o sagrado. A dança permite explorar, criar e dar formas à própria corporeidade. São idéias, traduzidas por uma linguagem corporal, que permitem expressar e comunicar mensagens, sensibilizando para a adoração, o belo, o estético, o cultural, o social e o espiritual. Em vez de orar com palavras, ora-se com gestos, expressando orações mediante de movimentos corporais dançantes (COIMBRA, 2003).

A dança quando inserida em contextos religiosos retoma sua noção de sagrado, de possibilidade de comunicação com o divino. Quando, por meio da dança, se entra em contato com o 
sagrado, o corpo vive a experiência do sagrado. De maneira que o corpo se torna um elemento essencial para a relação com o divino. A dança é seguramente uma forma de oração realizada pelo corpo que se exerce entre os carismáticos. Ela é acolhida pelo catolicismo visando uma expressão mais perfeita do homem na busca do contato com Deus.

"A dança é capaz de levar o ser dançante à vivência de sua corporeidade através da misteriosa consagração da totalidade existencial - nem só corpo, nem só espírito" (LARA, 2000, p.62). Ela evidencia as necessidades humanas e sobre-humanas expressas numa mesma corporeidade (LARA, 1999b). O corpo pode ser visualizado como portador de conhecimento, de expressão e que adquire relevância na dança (LARA, 2000).

Como corpo dançante, desenha-se formas, conta-se histórias, penetra-se no espaço e no tempo, interagindo no corpo e com o corpo. É nesse instante de fazer que, para Coimbra (2003) a dança dilata os espaços de abertura às trocas com as pessoas, com a cultura, com o contexto e com os fatos da vida. A dança, uma das expressões dessa cultura, é, certamente, de acordo com Lara e Oliveira (1996), um dos elementos chaves de contribuição a uma visualização do homem em todas as suas potencialidades.

Por outras palavras, ela é um ato coletivo que ajuda a criar um clima fraterno e alegre entre os participantes. Quando num conjunto de indivíduos uns se encontram na presença corporal de outros a interação social pode ser realmente estabelecida. A Renovação Carismática Católica tem o propósito de favorecer à vida cotidiana partilhada com os outros, um clima fraterno e de congraçamento. De acordo com Rabelo (2011), convém lembrar que o corpo de um pentecostal preenchido pela graça divina torna-se um foco a partir do qual o poder do sagrado flui aos demais. Sem dúvidas é construída uma corporeidade singular pelo modo que a RCC propõe a realidade partilhada.

O corpo, através da dança se mostra parte de um contexto cultural e social, assim como anunciam Le Breton (2012), Csordas (2008) e Mauss (2003). Ele se mostra como "vetor semântico" (LE BRETON, 2012, p.7), de forma que é nele que a evidência da relação com o mundo é construída. É dele que nasce e se propaga as significações que fundamentam a existência individual e coletiva; é o lugar e o tempo nos quais a existência toma forma, servindo de sistemas simbólicos que compartilha com os membros da comunidade.

A abordagem da dança realizada não toca diretamente à Educação Física, mas proporciona uma abordagem mais genérica que autoriza a transição para essa especificidade. Tal reflexão representa uma construção fundante para inúmeras possibilidades que constituem o universo da dança, que é apropriado em parte pela Educação Física como elemento da cultura de movimento. No entendimento de Silvério (2002), um dos focos de estudos da Educação Física é o corpo, talvez uma 
de suas maiores preocupações, pois acredita-se que é papel da Educação Física apontar elementos da sociedade, ampliando as possibilidades do corpo se manifestar como realmente ele é.

As análises que relacionam o corpo à dança de carismáticos se revelam como um elemento de investigação novo. Muitos estudiosos da RCC centram seus interesses nas práticas corporais como um todo, não tecendo minúcias acerca de certas particularidades consoante a dança. No entanto, direcionar o olhar para a corporeidade apreendida por meio da dança em um contexto religioso não é demandar de um objeto de investigação puramente novo. É reivindicar uma posição que permita registrar extensões, conexões e trocas que se encontram sempre em jogo na dinâmica social (RABELO, 2011). Em outras palavras, é perceber que a cultura, os sentidos e os significados emanam do corpo.

Que seja registrada a recomendação de futuras pesquisas com o intuito de construir olhares acerca da corporeidade dos carismáticos. Em especial, das danças realizadas pelos fiéis em meio ao seu cotidiano de oração, a fim de auxiliar a construção de novos olhares, sejam eles pautados na interação social, tensão do sagrado e profano, ou não. Carranza (1998), anuncia que por mais que se pense a Renovação Carismática como um Movimento homogêneo, no seio de cada grupo são encontradas práticas diferenciadas. Seria interessante reunir um montante de trabalhos a fim de encontrar pontos de aproximações e distanciamentos de elementos evidenciados pelo corpo e suscitados por meio da dança. 


\section{REFERÊNCIAS BIBLIOGRÁFICAS}

ADLER, P.; ADLER, P. Membership roles in field research. Beverly Hills, SAGE, 1987.

ANGROSINO, Michael. Etnografia e observação participante. Porto Alegre, Artmed, 2009.

ALMEIDA, Arthur José Medeiros de. Esporte e cultura: esportivização de práticas corporais nos jogos dos povos indígenas. 2008, 131f.. Dissertação (Mestrado em Educação Física) - Faculdade de Educação Física, Universidade de Brasília, Brasília, 2008.

BEJART, Maurice. Prefácio. In: GARAUDY, Roger. Dançar a vida. Rio de Janeiro, Nova Fronteira, 1980.

BERGER, Peter; LUKMAN, Thomas. Os fundamentos do conhecimento na vida cotidiana. In: A construção social da realidade. 33ª ed, Petrópolis, Vozes, 2011.

BIANCONI, Jéssica. Proselitismo televisivo e corporeidades em uma expressão do catolicismo. Motriz. v.14, n.1, 2008.

BORGES, Célia Maia. Santa Teresa e a espiritualidade mística: a circulação de um ideário religioso no Mundo Atlântico. In: $O$ espaço atlântico de antigo regime: poderes e sociedade. Lisboa, Universidade Nova de Lisboa, p. 1-10, 2005.

BOURDIEU, Pierre; CHAMBOREDON, Jean-Claude; PASSERON, Jean-Claude. A profissão do sociólogo: preliminares epistemológicas. Petrópolis, Vozes, 1990.

CALDEIRA, Solange Pimentel. A religiosidade na dança: entre o sagrado e o profano. Revista história em reflexão. $\quad$ v.2, n.3, 2008. Disponível em: <http://www.historiaemreflexao.ufgd.edu.br/A5/A\%20RELIGIOSIDADE\%20NA\%20DANCA\%20entre\% 200\%20sagrado\%20e\%200\%20profano.pdf>. Acesso em: 30 março 2014.

CARRANZA, Brenda Maribel. Renovação Carismática Católica: origens, mudanças e tendências. 1998, 260f.. Dissertação (Mestrado em Sociologia) - Instituto de Filosofia e Ciências Humanas, Universidade de Campinas, São Paulo, 2008.

CATECISMO DA IGREJA CATÓLICA. São Paulo, Loyola, 2003.

COIMBRA, Isabel. Louvai a Deus com danças. Belo Horizonte, Diante do trono, 2003.

CSORDAS, Thomas. Corpo, significado e cura. Porto Alegre, UFRGS, 2008.

DURKHEIM, Emile. As formas elementares da vida religiosa. São Paulo, Abril Cultural, 1996. 
FERREIRA, Francirosy Campos Barbosa. Teatralização do sagrado islâmico: a palavra, a voz e o gesto. Religião \& Sociedade, v. 29, n. 1, p. 95-125, 2009.

FLICK, Uwe. Introdução a pesquisa qualitativa. 3ª. ed. Porto Alegre, Artmed, 2009.

GARAUDY, Roger. Dançar a vida. Rio de Janeiro, Nova Fronteira, 1980.

GEERTZ, Clifford. A interpretação das culturas. Rio de Janeiro, LCT, 1989.

GÉLIS, Jacques. O corpo, a igreja e o sagrado. In: CORBIN, Alain; COURTINE, Jean-Jacques; VIGARELLO, Georges (Orgs.). In: História do corpo: da renascença às luzes. Tradução de Lúcia M. E. Orth. Rio de Janeiro, vozes, 2008. Pp.19-130.

GIBS, Graham. Análise de dados qualitativos. Porto Alegre, Artmed, 2009.

GIL, Antônio Carlos. Métodos e técnicas de pesquisa social. 5ª̣ ed. São Paulo, Atlas, 1999.

GIDDENS, Antony. Sociologia. Porto Alegre, Artmed. 2005.

GOFFMAN, Evring. A representação do eu na vida cotidiana. 10ª ed, Petrópolis, Vozes, 2002.

GOLDENBERG, Mirían. A arte de pesquisar: como fazer pesquisa qualitativa em Ciências Sociais. Rio de Janeiro, Record, 2004.

GUIMARÃES, Dom Pedro Brito. Eu vim para servir. Conferência Nacional dos Bispos do Brasil. 2015. Disponível em:http://www.cnbb.org.br/artigos-dos-bispos-1/dom-pedro-brito-guimaraes1/15875-eu-vim-para-servir. Acesso em: 12 março 2015.

HERTZ, Robert. A preeminência da mão direita. In: Religião e sociedade. Rio de Janeiro, Civilização Brasileira, 1980, p.99-128.

JEUDY, Henri Pierre. Entre o repouso e o movimento. In: O corpo como objeto de arte. São Paulo, Estação liberdade, p. 58-70, 2002.

KUNZ, Elenor. Transformação didático-pedagógica do esporte. 7ª̣. ed, ljuí,Unijuí, 2010.

LAKATOS, Eva Maria; MARCONI, Marina de Andrade. Sociologia Geral. São Paulo, Atlas, 1999.

LARA, Larissa Michelle. Dança: dimensão sagrada ou profana? Conexões. v.1,n.2,dez,1999a. Disponível em: http://fefnet178.fef.unicamp.br/ojs/index.php/fef/article/view/345. Acesso em 15 maio 2013.

As danças do sagrado no profano: transpondo tipos e espaços em rituais do candomblé. 1999, 207f.. Dissertação (Mestrado em Educação Física) - Faculdade de Educação Física, Universidade Estadual de Campinas, São Paulo, 1999b. 
Danças de orixás e educação física: delineando perspectivas a partir dos rituais do candomblé. Revista da Educação Física. v.11, n. 1, 2000. Disponível em: <http://www.periodicos.uem.br/ojs/index.php/RevEducFis/article/view/3792>. Acesso em: 30 março 2013

; OLIVEIRA, Amauri A. Bássoli de. Expressão dos corpos pela dança na vivência e reflexão em meio escolar. Revista da Educação Física. v.7, n.1, 1996. Disponível em: $<$ http://periodicos.uem.br/ojs/index.php/RevEducFis/login?source=\%2Fojs\%2Findex.php\%2FRevEduc Fis\%2Farticle\%2FviewFile\%2F3856\%2F2650>. Acesso em 30 março 2013.

LE BRETON, David. A sociologia do corpo. Rio de Janeiro, Vozes, 2012.

MACHADO DE VARGAS, Lisete Arnizaut. Escola em dança: movimento, expressão e arte. Porto Alegre, Mediação, 2007.

MARIZ, Cecília Loreto. Comunidades de vida no Espírito Santo. Tempo Social, revista de sociologia da USP, v. 17, n. 2, p. 254, 2005.

MAUÉS, Raymundo H. "Bailando com o Senhor": técnicas corporais de culto e louvor (o êxtase e o transe como técnicas corporais). Revista de antropologia. n.1, v.46, 2003. Disponível em: $<$ http://www.scielo.br/scielo.php?script=sci arttext\&pid=S0034-77012003000100001 >. Acesso em: 30 março 2013.

Algumas técnicas corporais na renovação carismática católica. Ciências sociais e religião, 2007, p.401-421.

Raymundo; SANTOS, Kátia Bárbara; SANTOS, Marinéa Carvalho. Em busca da cura: ministros e "doentes" na Renovação Carismática Católica. Revista ANTHROPOLÓGICAS, v. 13, n. 1, 2002.

MAUSS, Marcel. As técnicas corporais. In: Sociologia e antropologia. São Paulo, EPU/Edusp, 2003, p.399-422.

PAPA FRANCISCO. A santa sé: discurso do Papa Francisco aos membros da "catholic freternity of charismatic conventant communities and fellowships". Disponível em: http://m2.vatican.va/content/francesco/pt/speeches/2014/october/documents/papafrancesco 20141031 catholic-fraternity.pdf. Acesso em: 12 março 2015.

PERERIRA, Edilson. O espírito da oração ou como carismáticos entram em contato com Deus. Religião e Sociedade, Rio de Janeiro, v.29, n.2, 2009. Disponível em: http://www.scielo.br/pdf/rs/v29n2/v29n2a04.pdf. Acessoem: 21/02/14. 
RABELO, Miriam. Estudar religião a partir do corpo: algumas questões teórico-metodológicas. Caderno CRH, Salvador, v.24, n.61, janeiro/abril, 2011. Disponível em $<$ http://www.scielo.br/scielo.php?script=sci arttext\&pid=S0103-49792011000100002>. Acesso em: 30 março 2014.

RENOVAÇÃO CARISMÁTICA CATÓLICA BRASIL. A história da RCC: história mundial da RCC. s/d. Disponível em: http://www.rccbrasil.com.br/interna.php?paginas=42. Acesso em: 13 março 2015.

RIGONI, Ana Carolina Capellini; PRODÓCIMO, Elaine. Corpo e religião: marcas da educação evangélica no corpo feminino. Rev. Bras. Ciênc. Esporte, Florianópolis, v. 35, n. 1, p. 227-243, jan./mar. 2013.

RODRIGUES, José Carlos. Tabu do corpo. Rio de Janeiro, Achamé, 1983.

RUMSTAIN, Ariana. A balada do Senhor. In: MAGNANI, José Guilherme Cantor Magnani; SOUZA, Bruna Mantese (Orgs.). Jovens na metrópole: etnografias de circuitos de lazer, encontro e sociabilidade. São Paulo, Editora Terceiro Nome, 2007

SANTOS, Marcos Paulo de Oliveira. As representações sociais das práticas corporais na comunidade Kalunga-GO. 2011, 101f.. Dissertação (Mestrado em Educação Física) - Faculdade de Educação Física, Universidade de Brasília, Brasília, 2011.

SANTOS, Rosirene Campêlo dos. O processo ritual nas festas da comunidade kalunga de Teresina de Goiás. 2013, 124f.. Dissertação (Mestrado em Educação Física) - Faculdade de Educação Física, Universidade de Brasília, Brasília, 2013.

SARAIVA, Maria do Carmo; FIAMONCINI, Luciana; ABRÃO, Elisa; KRISCHKE, Ana Alonso. Dança e seus elementos constituintes: uma experiência contemporânea. In: SILVA, Ana Márcia; DAMIANI, lara Regina (Orgs.). Práticas corporais: experiências em educação física para a outra formação humana. v.3. Florianópolis: Nauemblu ciência e arte, 2005.

SILVA, Thaís de Queiroz e. Práticas corporais e as experiências extraordinárias em core energéticia. 2014, 135f.. Dissertação (Mestrado em Educação Física) - Faculdade de Educação Física, Universidade de Brasília, Brasília, 2014.

SILVEIRA, Emerson Sena. Pluralidade Católica: um esboço de novos e antigos estilos de crença e pertencimento. In: Sacrilegens, v.1, n.1. 2004. Disponível em: http://www.urjf.br/sacrilegens/files/2009/1-11.pdf. Acesso em 23 fevereiro 2014. . Corpo e juventude nas "cristotecas" católico-carismáticas. In: Revista Brasileira de

História das Religiões. v.3, n.9, janeiro, 2011. Disponível em:
$<$ http://www.dhi.uem.br/gtreligiao/pub.html>. Acesso em 23 fevereiro 2013. 
SILVÉRIO, Katiúscia Rodrigues. Aspectos da imagem corporal dos presbiterianos de Jataí-GO. 2002, 98f.. Dissertação (Mestrado em Educação Física) - Faculdade de Educação Física, Universidade Estadual de Campinas, São Paulo, 2002.

SOFIATI, Flávio Munhoz. Elementos sócio-históricos da renovação carismática católica. Estudos de Religião, v.23, n.37, julho/dezembro, 2009. Disponível em: $<$ https://www.metodista.br/revistas/revistas-ims/index.php/ER/article/viewFile/1528/1554. Acesso em: 30 março 2014.

STEIL, Carlos Alberto. Catolicismos e memória no Rio Grande do Sul. Debates do NER, v. 1, n. 5, 2004.

TAMBIAH, Stanlei. A performative approach to ritual. In: Culture, Thought, and Social Action. Cambridge, Harvard University Press, p. 123-166, 1985.

TELLES, Cida. Caminhos em busca do Santo dos Santos. Trindade, MCM, 2015

TERRA, Alessandra Matos. Corpos que dançam na diversidade e na criação. 2013, $130 f .$. Dissertação (Mestrado em Educação Física) - Faculdade de Educação Física, Universidade de Brasília, Brasília, 2013. 


\section{LISTA DE ANEXOS}

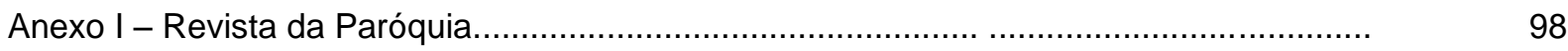

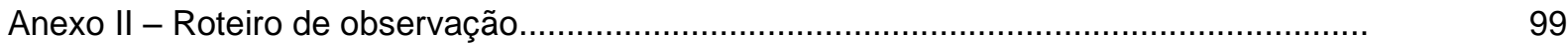





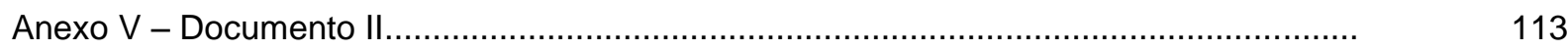

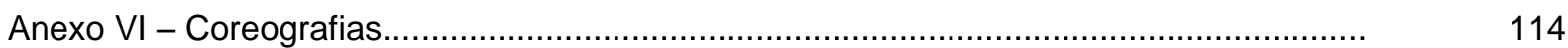




\section{Anexo I - Revista da Paróquia}

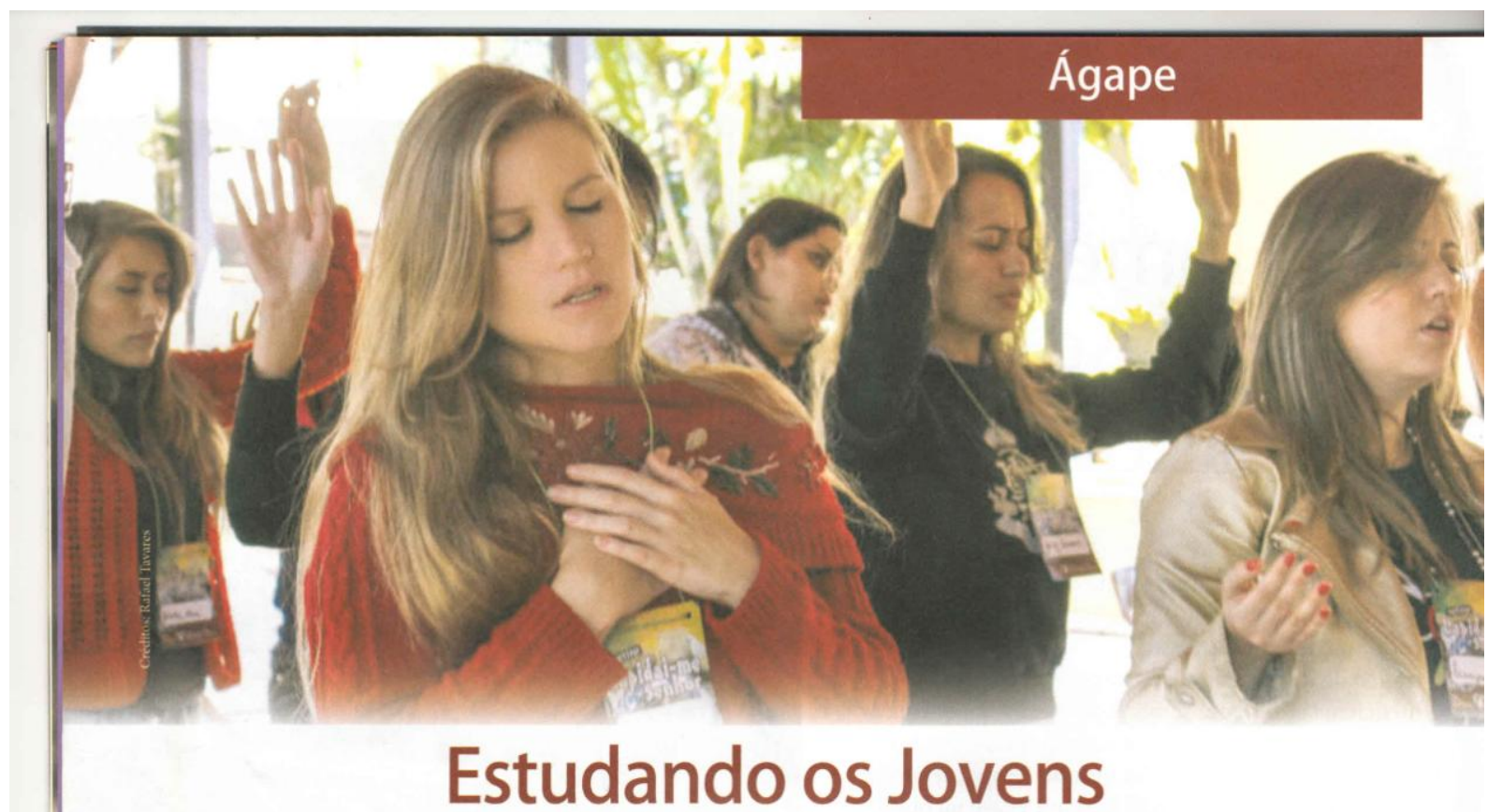

Uma pesquisa do Programa de Pós-Graduação Stricto Sensu (mestrado) da Universidade de Brasília, em parceria com o Núcleo de Estudos sobre Corpo e Natureza (Necon), está sendo desenvolvida com o Grupo Agape por mim, sob a orientação da Prof. Dr ${ }^{a}$ Dulce M. F. de Almeida.

Tal pesquisa tem por objetivo compreender a corporeidade de jovens católicos pertencentes à Renovação Carismática (entendendo a corporeidade como um elemento/corpo que é constituído não só pelo componente biológico, como também pelo cultural e social). O estudo tem como finalidade, responder a seguinte pergunta "qual é o significado da vivência da corporeidade dos jovens do movimento católico carismático, considerando a dança como uma prática corporal que pode possibilitar processos de interação social e a relação com o sagrado?". Com o intuito de responder tal pergunta, desenvolvi uma pesquisa de abordagem qualitativa, com orientação etnográfica, sendo utilizadas como técnicas a entrevista, a observação (registrada em diário de campo e por filmagens) e a análise de documentos.

Ao considerar a relação entre corpo, dança e religião, visto que tais temáticas se fazem presentes no estudo, pode-se perceber que ainda há poucas pesquisas que abarcam tais temáticas. A medida que se coloca em foco a análise da corporeidade e da dança em particular, entre jovens da Renovação Carismática Católica, as pesquisas na área da Educação Física encontramse ainda mais esporádicas. Diante de tal panorama de escassez perante as pesquisas de delineamento religioso e católico na limiaridade do campo de conhecimento e intervenção da Educação Física, optou-se por fortalecer as pesquisas de âmbito religioso, em especial vinculadas a Renovação Carismática Católica.

Estudar um grupo, com o perfil do Grupo de Oração Ágape, é relevante à medida que se trata de um grupo que ainda não foi tomado como objeto de investigação científica. Além disso, tendo-se como um dos focos da pesquisa os processos de interação, entre os participantes do movimento religioso e da dança, como uma prática corporal no cenário da Renovação Carismática, temse conhecimento - e, registre-se, esse fato chama à atenção - suas atribuições ou objetivos são voltados à afetividade e à sexualidade, com possibilidade de formação de casais de namorados, a fim de buscarem viver retamente à luz da doutrina católica.

Letícia R. Teixeira Participante do grupo

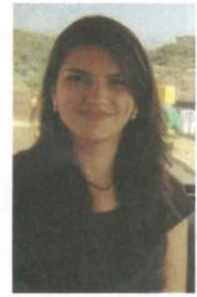

\section{cerrado pneus}

CENTRO AUTOMOTIVO

\section{- PNEUS \\ - FREIOS}

- SUSPENSÃO

- ALINHAMENTO

- BALANCEAMENTO

- INJEÇÃo ELETrónICA

\section{PNEUS E SERVIÇOS}

Loja - Jardim Europa 62 3954-3017 Av. dos Alpes, 1985, Qd. 80, Lt. 14/15

Loja - Garavelo 62 3922-6770

G0-040, Qd. 02, tt. 01

Garavelo, Goiania-Go

Loja - Extra T9 62 3558-464

Av. Millo, Jardim Europa

Hipermercado Extra - Loja interna

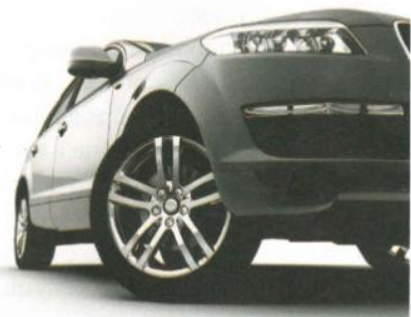

12 Revista Sagrada FEVEREIRO 2015 


\section{Anexo II - Roteiro de observação}

1. Onde fica o lugar da reunião?

2. Ator: Quais são as pessoas envolvidas?

3. Atividade: O que é desenvolvido em âmbito mais geral?

4. Objetos: Quais são as coisas físicas que estão presentes?

5. Ato: Como as pessoas (cada indivíduo) agem naquele contexto específico?

6. Evento.

a) Terço. b) Animação. c) Efusão. d) Pregação. e) Atividade comunitária. f) Outros/Qual?

7. Tempo: Como ocorre o sequenciamento dos eventos ou atos?

8. Meta/objetivo:

a) $\mathrm{O}$ que se pretendeu alcançar na atividade em geral? b) $\mathrm{O}$ que se pretendeu alcançar em cada evento específico?

9. Sentimento:

a) Qual o sentimento do grupo? b) Qual o sentimento de algum indivíduo específico? c) Qual o sentimento do pesquisador? 


\section{Anexo III - Entrevista Semipadronizada}

1. Ha quanto tempo você frequenta o Ágape ou a Paróquia Sagrada Família?

2. O que te levou a frequentar o Ágape?

3. Considerando sua condição de jovem participante de um grupo de oração vinculado à RCC, qual é o significado do corpo para você?

4. Tendo esse mesmo contexto, o que representa a dança? O que é a dança para você?

5. Para você quais são os momentos do grupo de oração que mais promovem interação social ou a troca/diálogo com os demais participantes?

6. Qual é a sua opinião sobre a proposta do grupo para promover a interação entre os jovens? Você teria alguma sugestão a fazer?

7. Quando você dança, participa do grupo através da dança, você se sente inserido/parte do grupo? Explique (como, de que forma).

8. Como você reconhece a relação do sagrado e do profano (na dança)?

9. A partir de sua participação no grupo, sua noção de sagrado e a vinculação com a dança foi alterada/modificada?

10. Como você percebe seu corpo durante a dança?

11. Você já ouviu falar que o Ágape forma casais de namorados? O que você acha disso? 
Anexo IV - Documento 1
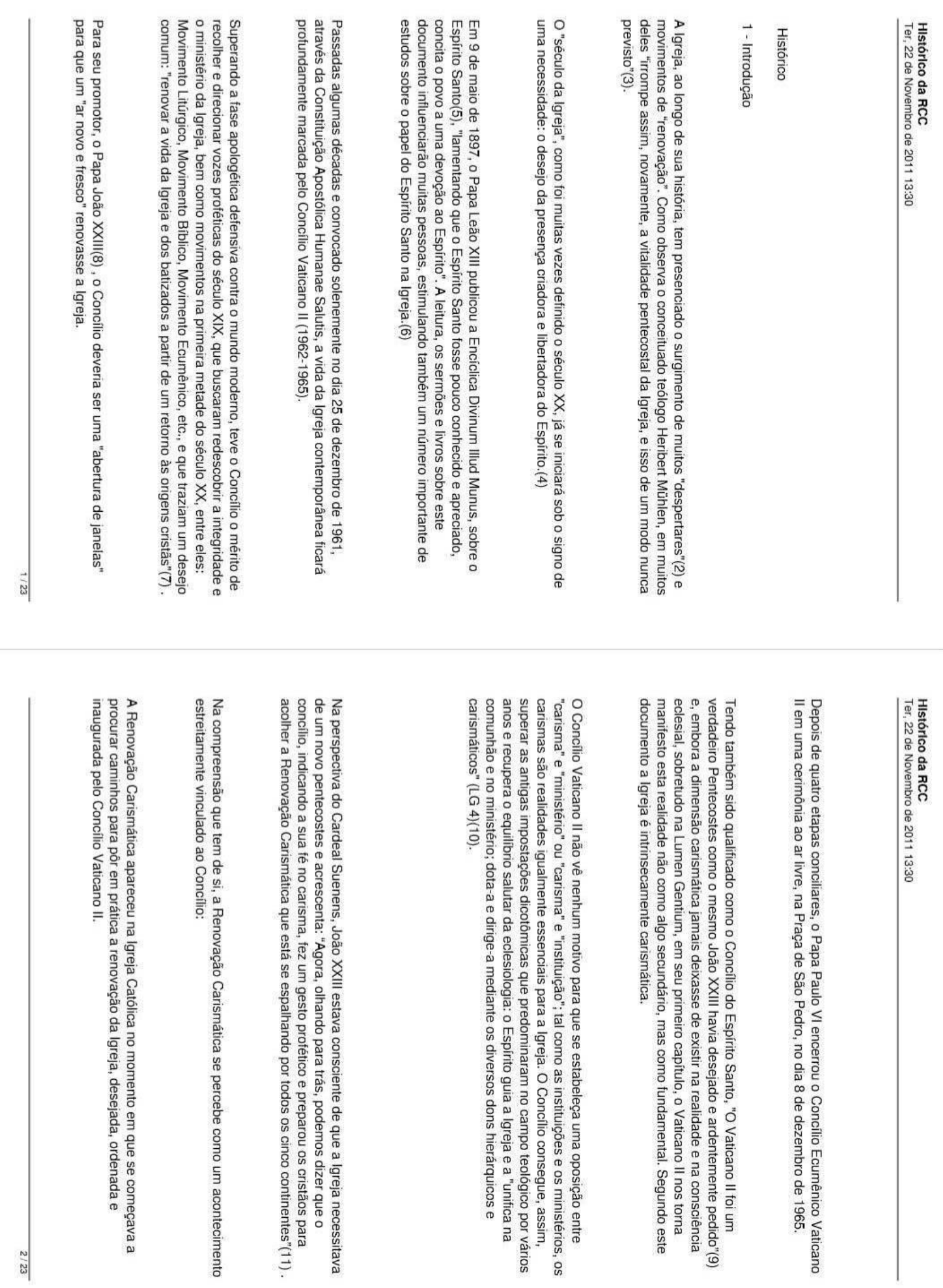


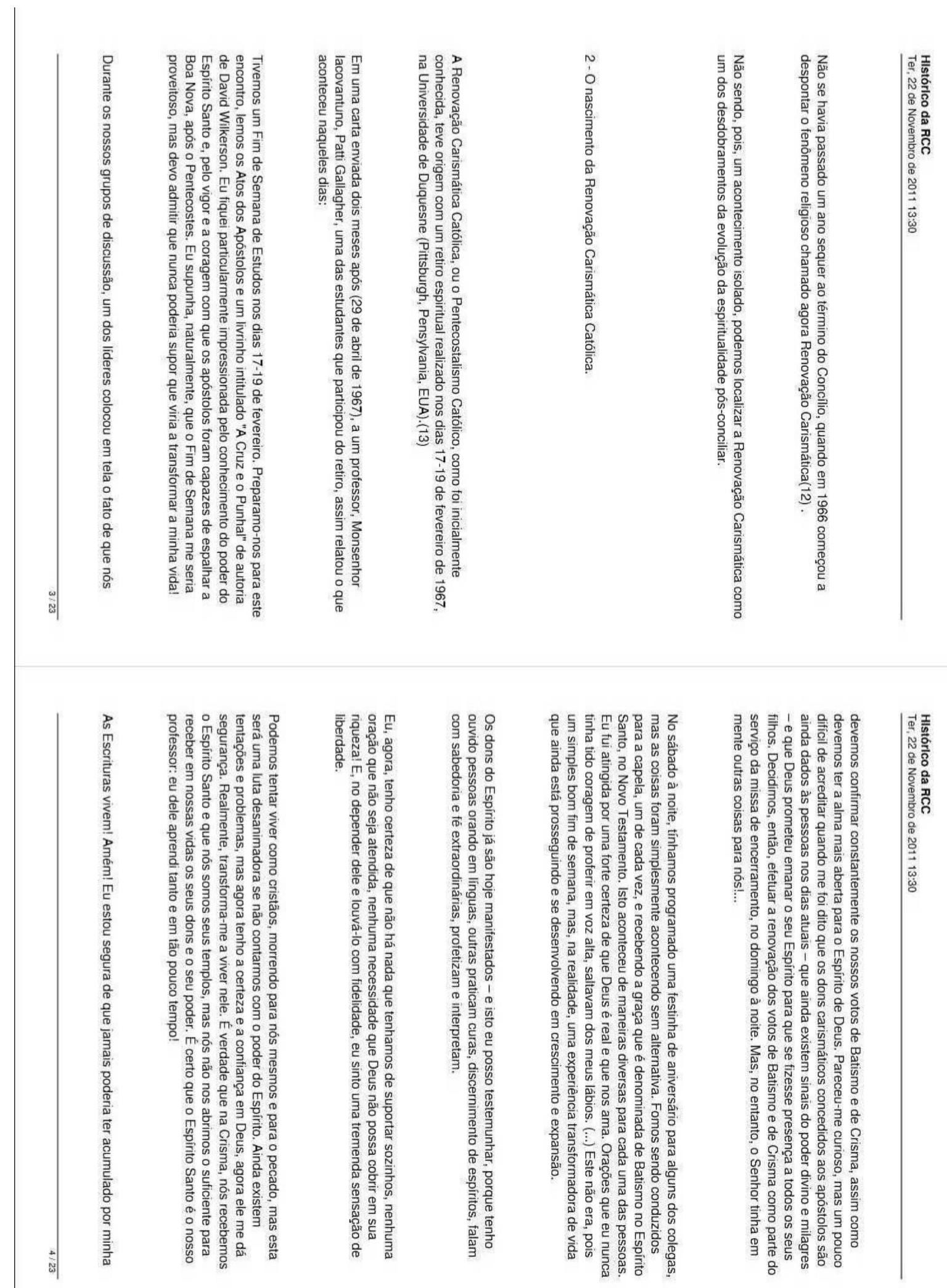



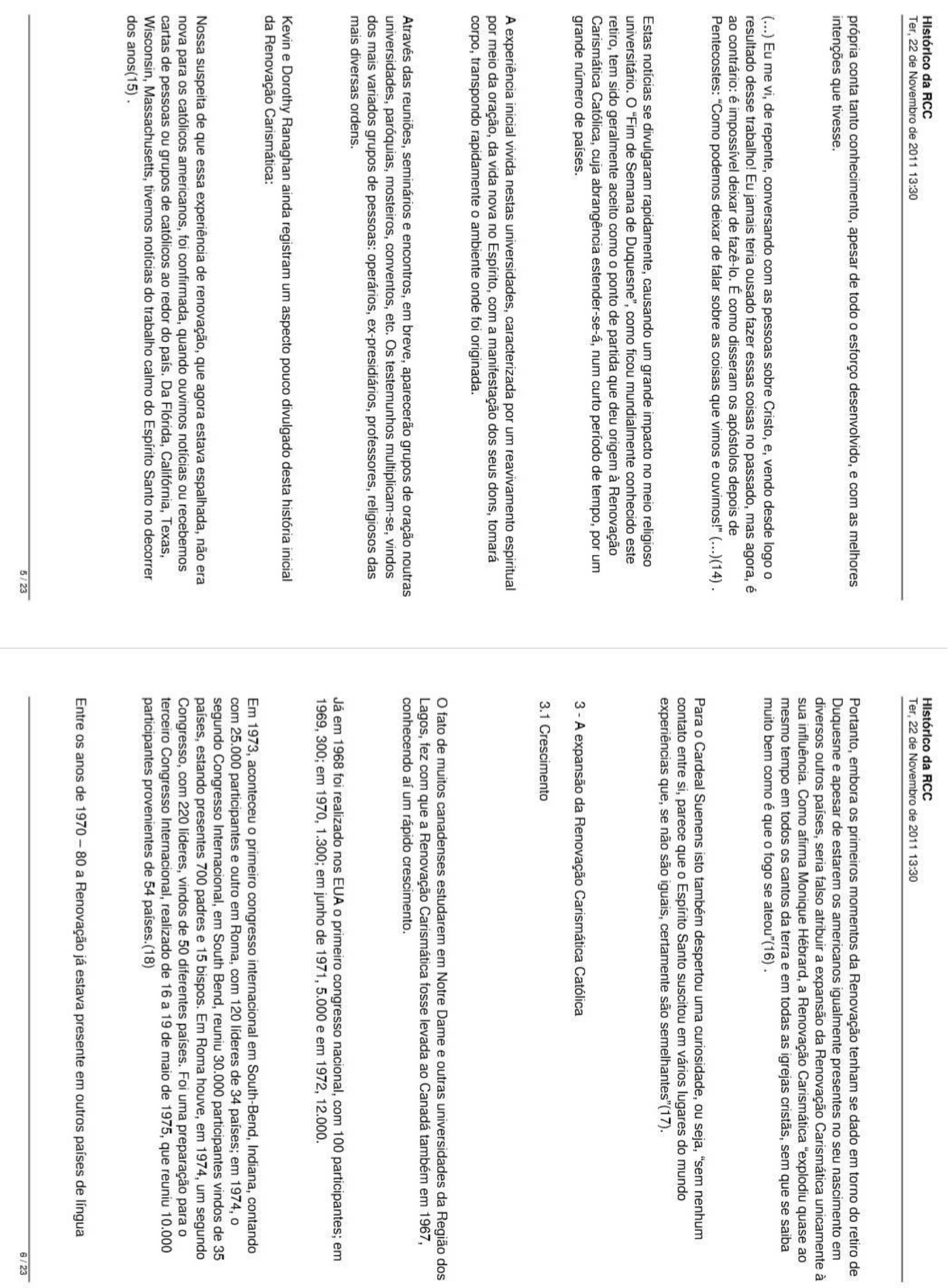

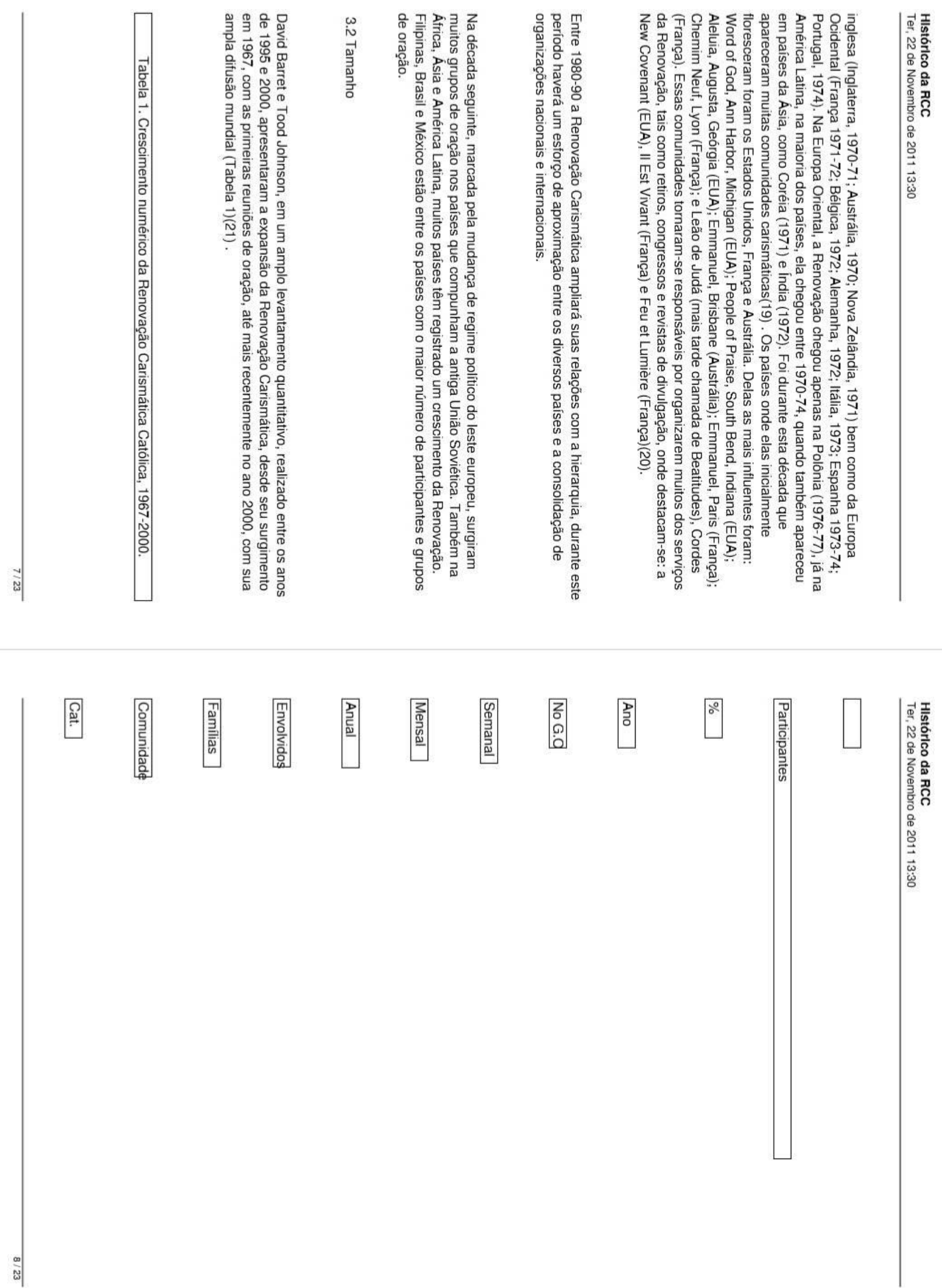

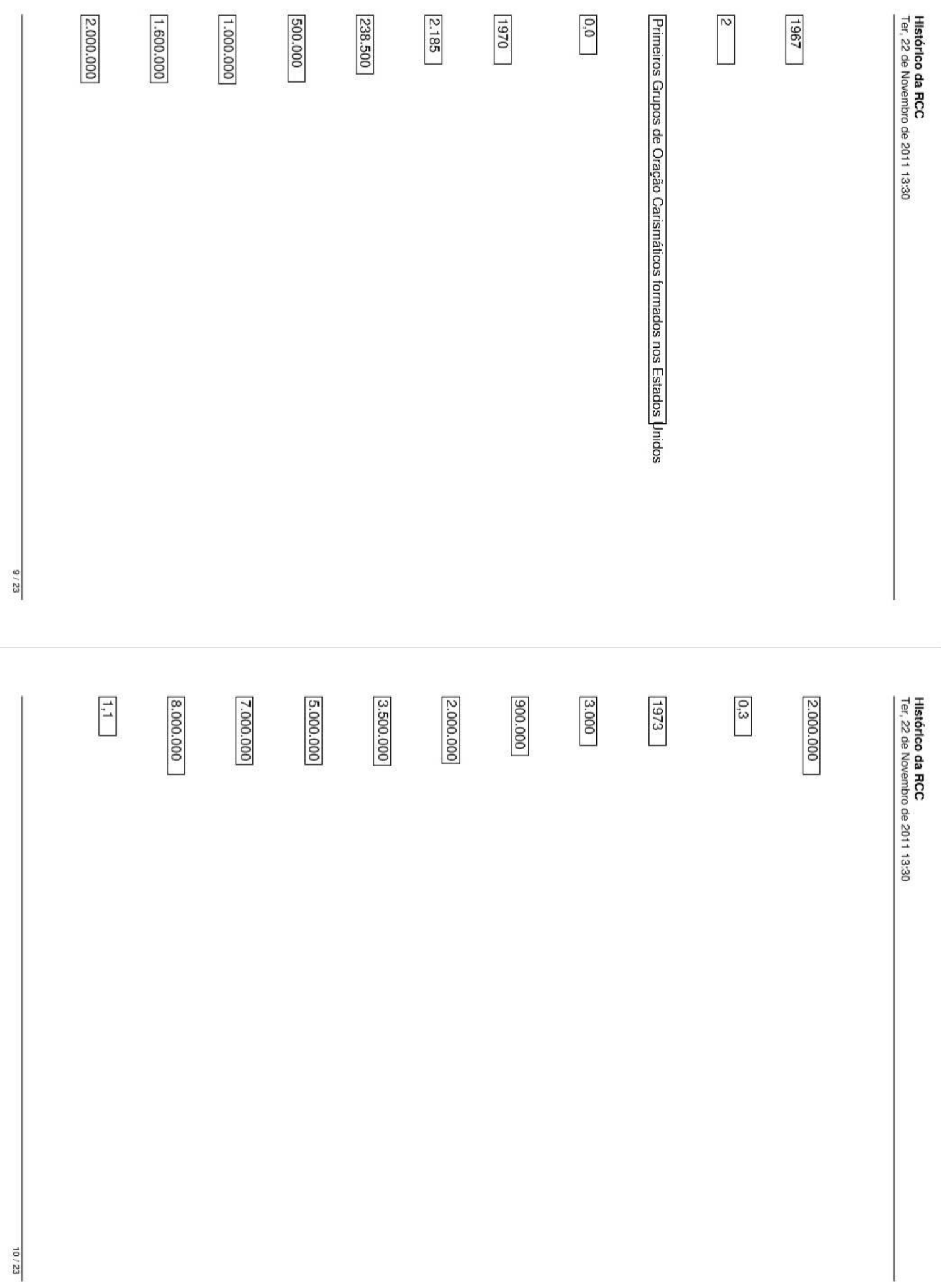





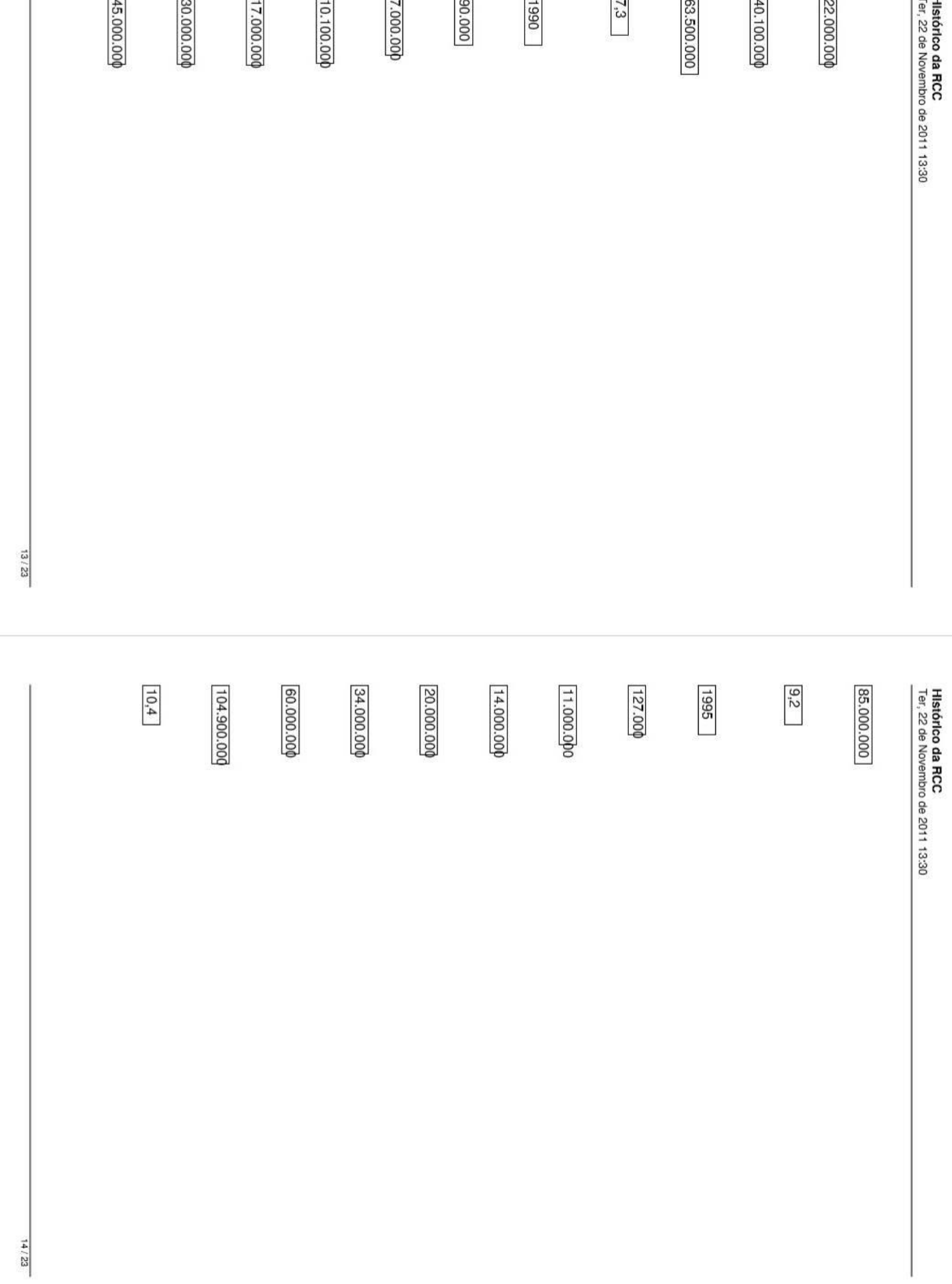

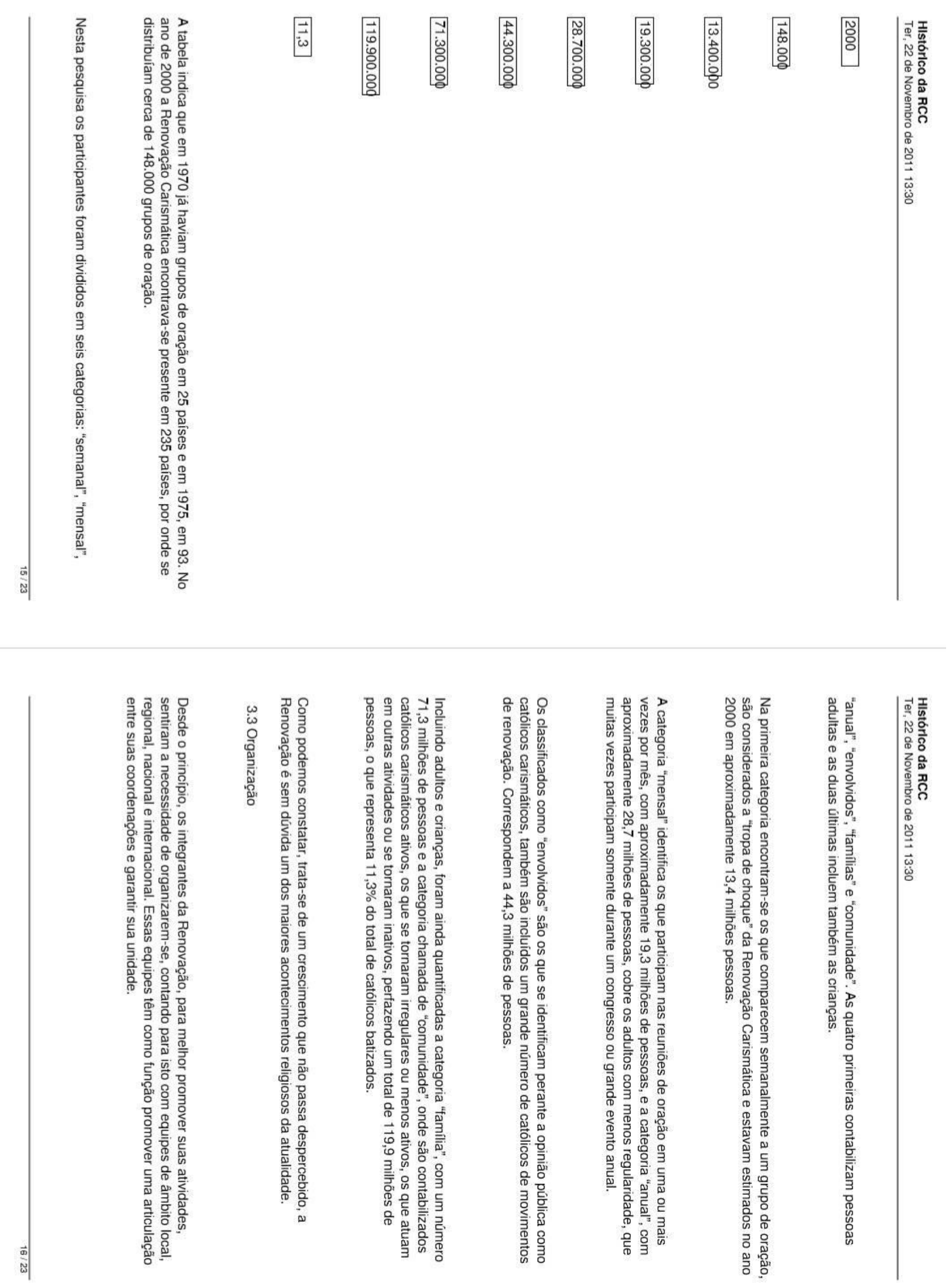



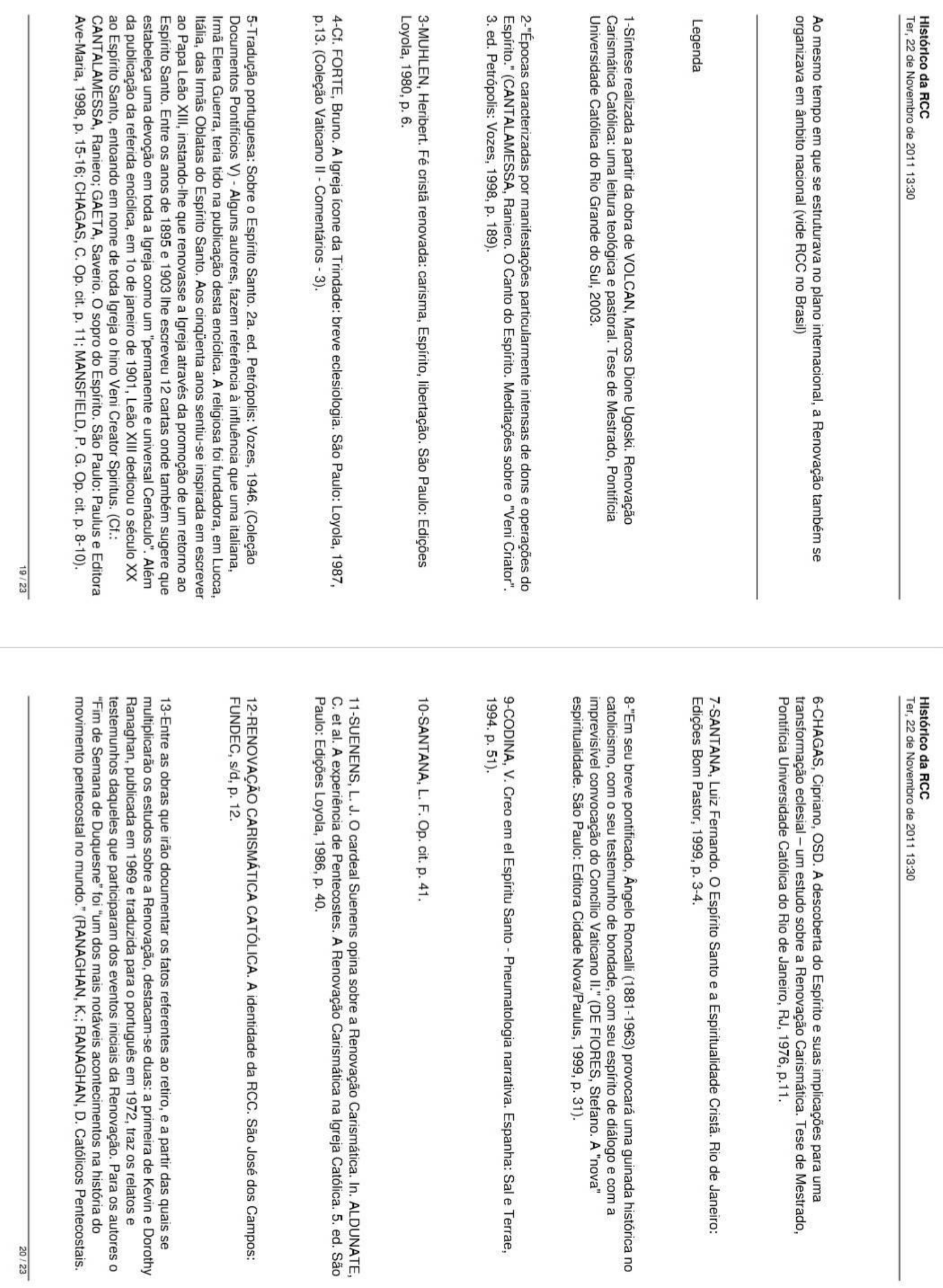

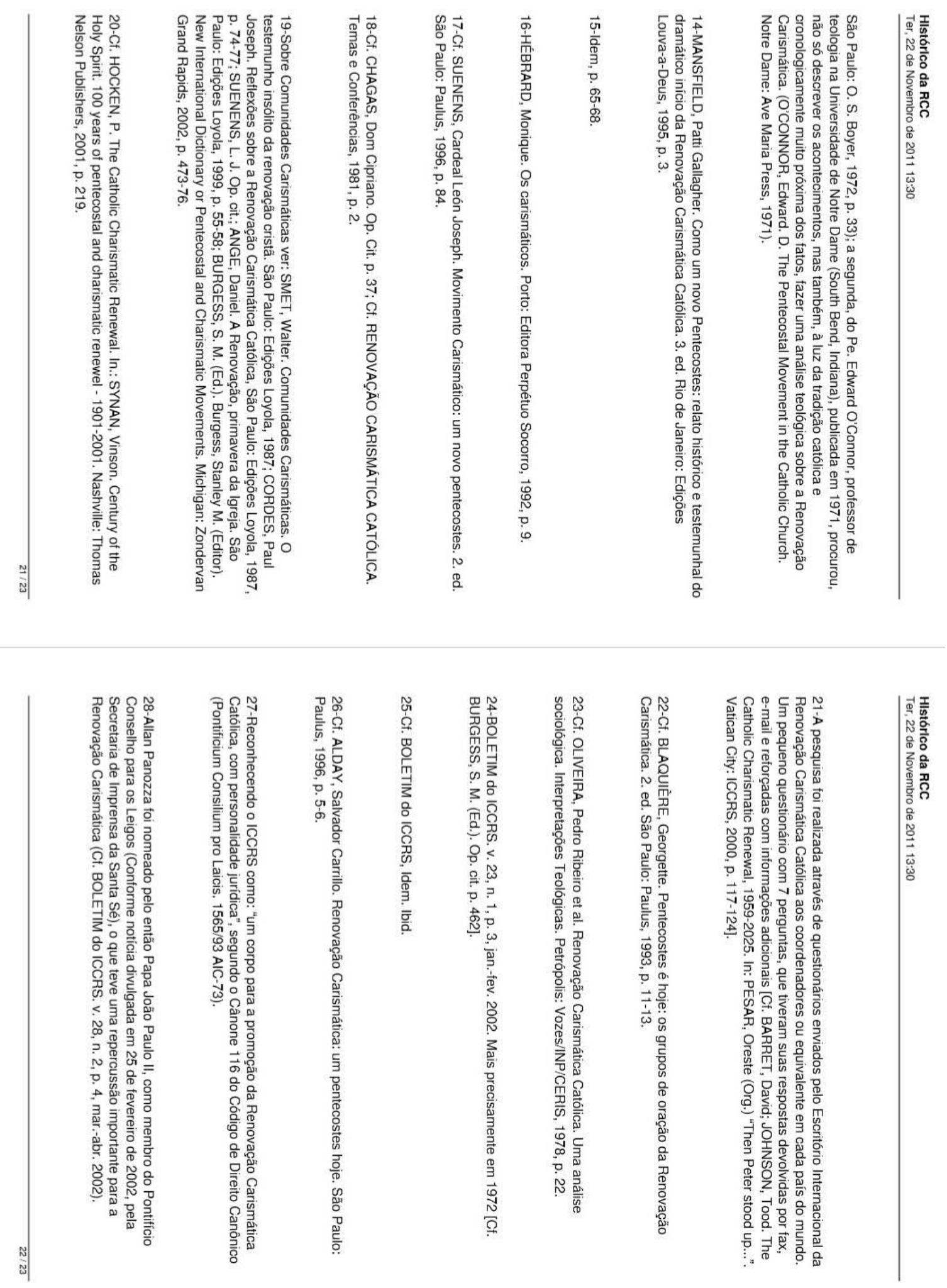


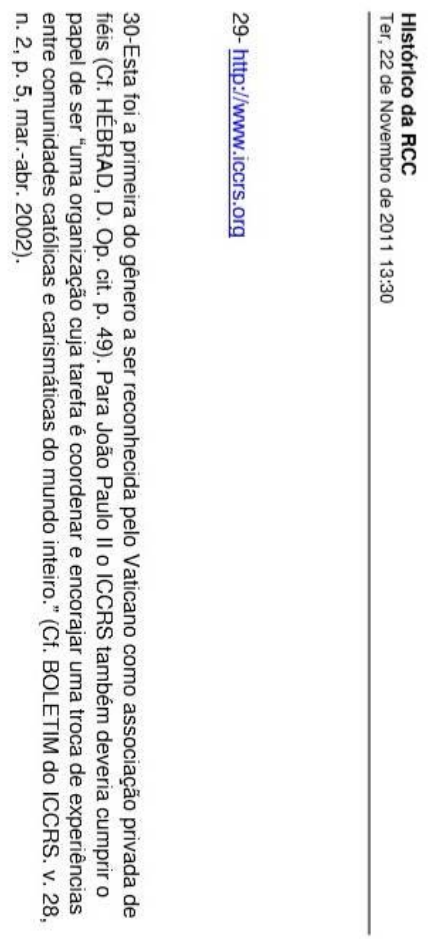


Anexo V - Documento II
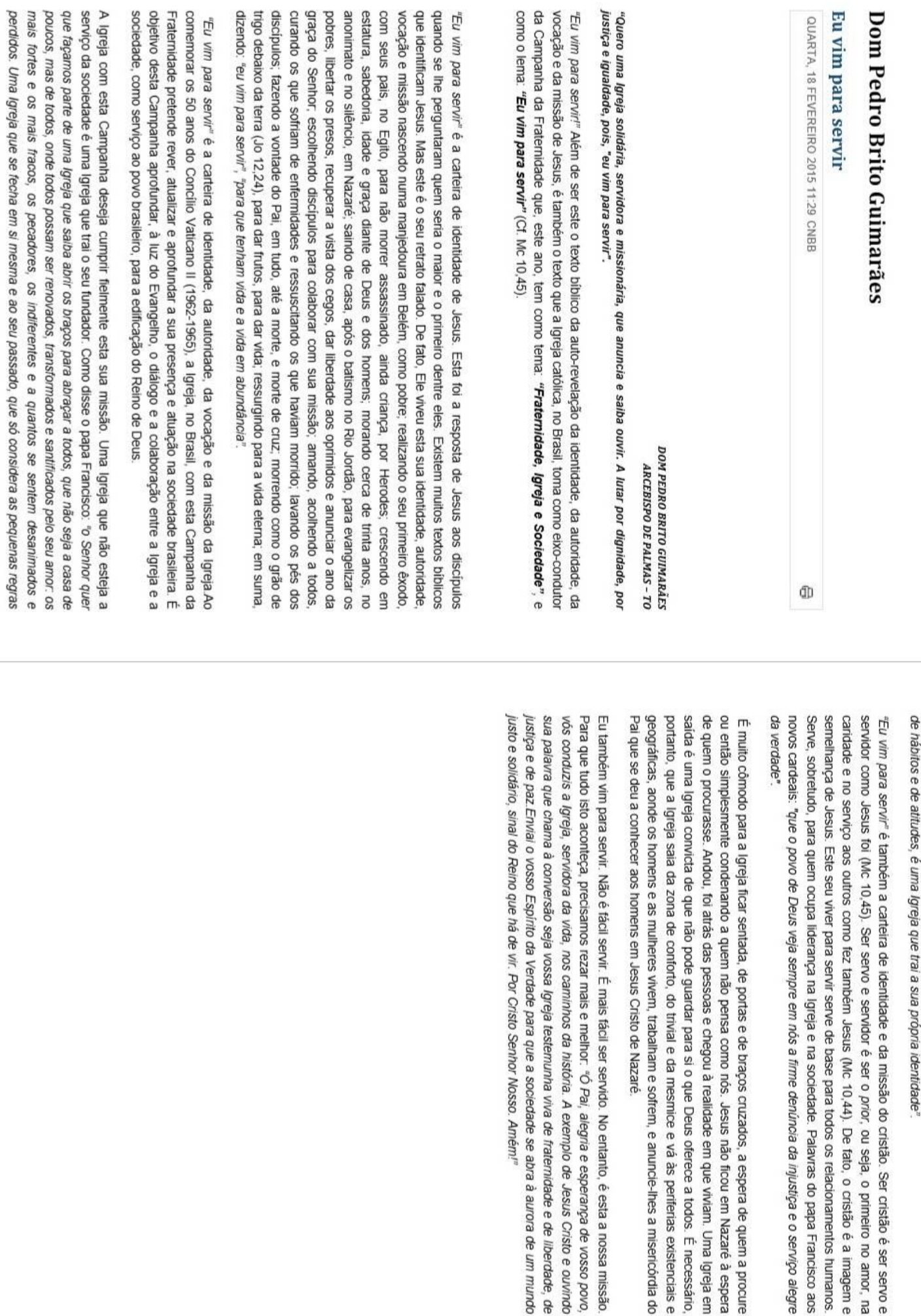


\section{Anexo VI - Coreografias}

\section{a) Catira para louvar}

Lucas pediu para que as pessoas saíssem dos bancos e se encaminhassem ao centro, onde ficava um corredor largo entre as cadeiras. Lucas incentivou as pessoas a perguntar coisas da vida do outro. Em seguida, ele iniciou um ritmo de catira no violão e a bateria acompanhou. Ao tocar o violão, ele movimentou o pé direito, para frente e para trás no ritmo da música. Em seguida, Renata (serva da intercessão) vai à frente e, ainda sem as músicas, propõe outro conjunto de técnicas. Ela bate três vezes (e) alternadamente os pés ao chão e em seguida, três palmas acima da cabeça. Todos a acompanharam. Assim fizeram repetidamente até terminar o tempo da introdução da música.

É uma nova forma de dançar (todos movimentam o pé direito à frente e atrás no ritmo da música). É uma nova forma de dançar (continuam movimentando os pés, a maioria percebe que Renata está com os braços pra trás e coloca também). É uma nova forma de louvar (mãos acima da cabeça se movendo de um lado para o outro, simulando a marcha com os pés). Bate a mão em cima (três palmas acima da cabeça). Bate o pé em baixo (pés alternados batem firmemente três vezes no chão) e vai (dois passos para frente - direita e esquerda somente -, levando as mãos também para frente do corpo, depois dois passos para trás retornando as mãos para a posição inicial). Bate a mão em cima, bate o pé em baixo e vai.

É uma nova forma de dançar, é uma nova forma de louvar, bate a mão em cima, bate o pé embaixo e vai. É uma festa (mãos acima da cabeça balançando de um lado para o outro e as pernas simulando a marcha), venha pra cá (movimento de chamar, alternando as mãos e realizando a marcha), parado ninguém (palmas da mão para frente com as palmas voltadas para frente, simulando o sinal de pare e a marcha), pode ficar (dedo indicador para cima, mãos à frente do peito, balançando de um lado para o outro, como um sinal de não e marchando), bate a mão em cima, bate o pé em baixo e vai.

Lucas pede para rapidamente para fazer uma fila única. Os participantes ficam tentando se ajeitar, mas a fila se forma rapidamente.

Põe a mão no ombro do irmão (colocam uma mão no ombro da pessoa da frente e os pés se movimentam para frente e para trás no ritmo da música), andando para mesma direção (dão três ou quatro passos à frente). Bate a mão em cima, bate o pé em baixo e vai.

Lucas pede para que todos virem para o fundo e todos dão meia volta. Põe a mão no ombro do irmão, andando para mesma direção (quase não se anda para frente), bate a mão em cima, bate o 
pé em baixo e vai (todos dão meia volta e se viram para ficar de frente para Lucas automaticamente, talvez porque os servos estão mais no fundo e eles se viram).

Lucas pede para que se separem, propondo a separação como sendo homens para um lado e mulheres para o outro. Então os homens formam uma coluna ao norte e se posicionam em frente às mulheres, que estão em coluna ao sul. A maioria se posiciona e coloca as mãos para trás $e$ alternando os pés na frente e atrás no ritmo da música. A grande maioria olha mais para o Lucas do que para a pessoa da frente. Lucas canta "mãozinha" várias vezes, talvez umas seis, até que as pessoas (inclusive Renata que está à frente) entendam que é para movimentar as mãos para frente e para trás, assim como estão fazendo com os pés. Em seguida, a canção continua.

Mãozinhas para frente e para trás, pezinhos também para frente e para trás (algumas talvez três - pessoas demonstraram aparente dificuldade motora, de fazer os movimentos dos pés juntamente com os das mãos; a maioria não olhava para frente, se olhava, não parecia estar focado na pessoa em sua frente, a não ser se fosse um conhecido, como no caso dos servos). Pulinhos para direita (três saltos curtos e rápidos para a direita), pulinhos para esquerda (três saltos curtos e rápidos para a esquerda) e vai (ao ter que dar passos à frente, a maioria das pessoas olhou para frente). Lucas pede para olhar para frente e incentiva a conversa com a pessoa à frente.

\section{b) Consagração à Nossa Senhora}

Óh, Minha Senhora e também minha mãe (alguns estendem às mãos em direção a imagem de Nossa Senhora das Graças, tendo as palmas das mãos voltadas para cima). Eu me ofereço, inteiramente todo a vós (com os cotovelos flexionados à frente, na altura dos ombros e com as mãos abertas apontam a mão para a cabeça e desce - os cotovelos e - as mãos acompanhando todo o corpo até os pés, retornando assim à posição ortostática). E em prova da minha devoção, eu hoje vos dou meu coração (estende-se as mãos em direção à imagem). Consagro a vós meus olhos (apontase as mãos para os olhos, alguns chegam a tocar as laterais da fronte), meus ouvidos (toca-se com as mãos abertas a parte externa do pavilhão auditivo), minha boca (toca-se a boca, ou os cantos desta). Tudo o que sou (com as mãos em concha acompanha-se o contorno do corpo da cabeça aos pés), desejo que a vós pertença (estende-se as mãos para a imagem). Incomparável mãe, guardaime e defendei-me, como coisa/filho e propriedade/consagrado vossa/vosso, amém (canta-se com as mãos estendidas para a imagem ou com a mão no coração).

Toda a coreografia é acompanhada realizando movimentos pendulares, na maioria das vezes laterais, causados pela transferência de peso de uma perna para outra no ritmo da música. 


\section{c) Dança da amizade}

Lucas pediu para que fossem formadas duas colunas: uma (de homens) em frente a outra (de mulheres) no corredor, e que os participantes se posicionassem entre as cadeiras. Em seguida, ele pede que a mão seja posta no ombro da pessoa à frente.

Essa é a dança, é a dança da amizade (com a mão direita no ombro direito da outra pessoa, movia-se o pé direito para frente e para trás), é alegria para lá e para cá (dificilmente se olhava a face da pessoa com quem se fazia dupla).

Laiá, laiá, laiá, lá (as pessoas uniam os braços pela parte medial da articulação do cotovelo e giravam, quase uma volta inteira, tendo como eixo a união pela parte medial da articulação do cotovelo), hei! (dois barcos impulsionados para cima). Laiá, laiá, laiá, lá (trocavam os braços e às vezes até a pessoa), hei!

Lucas indicou trocar o parceiro e a mesma coreografia foi feita. Lucas pede para que seja formada uma roda de quatro pessoas. Foram feitos quatro círculos com quatro pessoas em cada. De mãos dadas se dançou a música.

Essa é a dança, é a dança da amizade, é alegria para lá e para cá (com as mãos dadas moviam-se o pé direito para frente e para trás, muitas pessoas olhavam para o pé). Laiá, laiá, laiá, lá (girou para a direita), Hei! (jogavam os dois braços para cima e as mãos se desencontravam) Laiá, laiá, laiá, lá (uniram-se as mãos e giraram para a esquerda), Hei! (pude observar que a maioria olhava para a pessoa à sua frente).

Lucas pede para que se forme uma roda com oito pessoas, uniram 2 círculos e tudo se repetiu. Ele pediu para que seja formada a grande roda, todos se uniram lá no fundo e tudo se repetiu. Parece que essa roda foi a mais animada, porque tinha mais espaço para girar.

\section{d) Ele vem}

O tempo de cantar chegou (alguns batem palmas, outros colocam as mãos nas laterais da boca). O tempo de dançar chegou (a maioria continua nas palmas). Paulo pára a música e escolhe um menino e uma menina para dançarem na frente. Em seguida, ele escolhe mais duas pessoas que se recusam a subir, então ele escolhe um moço de óculos, e umas pessoas se mostram eufóricas, gritam e batem palmas.

O tempo de cantar chegou (o moço de óculos pula acima até do ritmo da música colocando as mãos na lateral da boca). O tempo de dançar chegou (o moço de óculos continua pulando, e o casal à frente dança dando um passo para cada lado). E Ele vem (pula girando o corpo para um lado, 
estendendo o braço que está voltado mais à frente, realizando o gesto de chamar com a mão), e Ele vem (pula girando para o outro lado). Saltando pelos montes (salta-se para as laterais, primeiro à direita e depois à esquerda). E Ele vem, e Ele vem. Saltando pelos montes (dois amigos do moço de óculos vão espontaneamente à frente e realizam os gestos para o mesmo lado). Os seus cabelos (agita-se as mãos abertas sobre a cabeça e salta-se girando para um dos lados), os seus cabelos (salta girando para o outro lado e agitando as mãos sobre a cabeça), são brancos como a neve (continuam a pular e gritar, mas alguns não agitam as mãos sobre a cabeça). E nos seus olhos (os meninos à frente, bem descontraídos fecham a mão de forma a deixar apenas o indicador e o dedo médio estendidos, colocam o antebraço à frente do rosto na posição horizontal, e deslizam o cotovelo para a lateral e para baixo fazendo com que os dedos acompanhem a área dos olhos de uma lateral a outra). E nos seus olhos (realiza-se o gesto com os dedos na frente dos olhos com a outra mão e movendo os quadris de um lado para o outro) há fogo (na posição ortostática, todos pulam). Incendeia, Senhor, a sua noiva, incendeia, Senhor, a sua igreja, incendeia, Senhor, a sua casa, vem me incendiar (pula-se com os braços ao alto realizando flexões de punho com as palmas das mãos voltadas para baixo).

\section{e) Eu sou feliz}

Lucas chama três servos à frente: Renata, Mateus e Marcos. Os participantes se encontravam em meio às cadeiras.

Eu sou feliz porque meu Cristo quer, felicidade não é coisa qualquer, eu sou feliz porque meu Cristo quer (palmas). Eu sou feliz porque meu Cristo quer, felicidade não é coisa qualquer, eu sou feliz porque meu Cristo quer (braços balançados de um lado para o outro). Paracuti, paracuticurá, paracuti, paracuticura (fizeram um movimento estranho e no mínimo engraçado, pois simularam o andar e o bater das asas de uma ave, Mateus simulava com a cabeça o movimento para frente e para trás - com o polegar na axila movimentava o cotovelo para cima e para baixo, e a cabeça para frente ao passo que os demais caminhavam agachados de um lado para o outro), pacuti rei (braços jogados para cima), ti (braços novamente aos céus), ticura, paracuti, paracuticurá (novamente o movimento simulando uma ave).

Lucas interrompe a música para explicar como se faz o paracuti, a saber: deve-se simular uma galinha andando pelo terreiro. Na sequência, ele dá continuidade à música.

Paracuti, paracuticurá, paracuti, paracuticura (muitos estão com o polegar na axila, um pouco agachados olhando para alguém e sorrindo, mas sem andar ou movimentar o pescoço), pacuti rei (braços jogados para cima), ti (braços novamente aos céus), ticura, paracuti, paracuticurá (alguns 
se arriscavam a andar, outros davam um passo para um lado e depois para o outro no ritmo da música).

Lucas incentiva os participantes e que estes ponham a vergonha de lado, que todos devem ir à frente. Forma-se um semicírculo e os servos dançam, no lugar dos participantes da primeira fila de cadeiras.

Eu sou feliz (polegar apontado para cima), porque meu Cristo quer (novamente, polegar apontado para cima), eu sou feliz porque meu Cristo quer. Felicidade não é coisa qualquer (com o indicador apontado para cima, as mãos são movidas de um lado para outro, simulando um não), eu sou feliz (polegar apontado para o peito) porque meu Cristo quer (indicador apontado para cima).

Paracuti, paracuticurá, paracuti, paracuticura. Pacuti rei. Ti, ticura, paracuti, paracuticurá (muitos andavam ou davam o passo para o lado no ritmo da música).

Eu danço feio (alguns apontavam o polegar para o peito e outros continuavam a representação da ave), porque meu Cristo quer (indicador apontado para o céu). Dançar feio não é coisa qualquer (com o indicador apontado para cima, as mão são movidas de um lado para outro, simulando um não), eu danço feio (polegar apontado para o peito) porque meu Cristo quer (indicador apontado para cima).

Abraço o irmão, porque meu Cristo quer (formam-se duplas ou trios, as pessoas abraçandose de lado). Abraçar o irmão não é coisa qualquer (com o indicador livre, aponta-se para cima, movese a mão livre de um lado para outro, simulando um não), abraço o irmão porque meu Cristo quer (dança-se com um passo para um lado e depois para o outro, mesmo abraçado).

Paracuti, paracuticurá, paracuti, paracuticura (os que estão em duplas tentam simular uma galinha andando, cada braço livre faz o movimento em referência ao bater da asa), pacutirei (braços jogados para cima, ao tempo em que a dupla é desfeita), ti (braços novamente aos céus), ticura, paracuti, paracuticurá.

Cutuco o irmão porque meu Cristo quer (as pessoas se cutucam na altura da cintura). Cutucar o irmão não é coisa qualquer, cutuco o irmão porque meu Cristo quer.

Paracuti, paracuticurá, paracuti, paracuticura (simulamo andar de uma galinha), pacuti rei (braços jogados para cima), ti (braços novamente aos céus), ticura, paracuti, paracuticurá (novamente o movimento que simulava uma galinha).

Cláudia chama Pedro para dançar à frente. Ele e Mateus demonstram habilidade na dança. Além de fazer os movimentos relatados para a parte do "paracuti", eles vão quase ao chão e retornam acima dançando e andando. Além do mais, eles movem o tronco e a cabeça para frente e para trás, com uma habilidade singular. Nenhum dos que estava dançando antes, dançavam assim. 
Normalmente, só batiam as asas e moviam as pernas ao som da música. Obviamente, todos que estavam observando a cena tinham um sorriso enorme estampado no rosto. Parece que Amanda já sabia que seria realizada tal performance. Quando Pedro foi convidado para ir à frente, já se sabia que iam dançar dessa maneira, tanto que antes de começar a dançar, ela tirou o celular do bolso e conseguiu filmar o conjunto de técnicas demonstrado por ambos. Lucas grita "êêê", todos batem palmas sorrindo e voltam para as suas cadeiras.

\section{f) Hoje é tempo de louvar a Deus}

Hoje é tempo de louvar a Deus. Em nós, agora, habita o teu Espírito (batem palmas e alternam o peso do corpo nós pés no ritmo da música). Então é só cantar (mãos em concha saem das laterais da boca e percorrem o espaço para frente e para o lado, desenhando as laterais de um triângulo no ar) e a Cristo exaltar (em posição ortostática, com as palmas das mãos voltadas para a frente, elevam-se as mãos para o alto, passando elas pela frente do corpo). E sua glória encherá este lugar (com as mãos lá no alto, voltam-se suas palmas para baixo e realizam-se flexões de punho). Vem louvar, vem louvar (as mãos movem-se alternadamente da lateral do tronco com o carpo estendido para a frente da barriga, flexionando os dedos/fechando a mão, simulando um movimento de chamar com as mãos e simultaneamente trocando o peso do corpo entre os pés).

No meio dos louvores Deus habita. É seu prazer cumprir o que nos diz (palmas). Então é só cantar e a Cristo exaltar. E sua glória encherá este lugar. Vem louvar, vem louvar. Glória a Deus, glória a Deus (mãos acima da cabeça movem-se, simultaneamente, de um lado para o outro).

\section{g) Homens de fé}

O mar (bate-se uma palma) se abriu (braços abertos na lateral para simular o movimento de abrir com as mãos) e o povo passou (todos ficam parados no mesmo lugar).

Cláudia tenta explicar que deve-se deslocar de uma extremidade da capela para a outra, independente das dificuldades de se chegar lá no tempo, ter um banco ou uma pessoa no caminho. Cláudia interrompe a explicação e diz que Ana questiona o fato de passar correndo em frente a Jesus (sacramentado no sacrário) e pergunta o que todos acham, na hipótese de "passar" outra música. Há uma bagunça de conversas, e a voz de Sandra sobressai-se ao dizer "Davi dançou na presença do Senhor" e todos sorriem. Após essa fala, Cláudia dá prosseguimento à coreografia.

O mar (uma palma) se abriu (simulação de abrir com as mãos), o povo passou (os servos atravessam com dificuldade o espaço da capela) e os israelitas louvavam ao Senhor (movimentos constantes de pronação e supinação de punhos, com os cotovelos flexionados, estando um braço na 
horizontal, na altura do peito e o outro braço na vertical na altura da cabeça). Para homens com fé (sinal de positivo com as mãos à frente do corpo, flexionando os dedos de modo a ficar com o polegar estendido e apontando para cima), Deus abre os caminhos (uma palma e o movimento de abrir com as mãos). O Mar se abriu (palma e o movimento de abrir com a mão) e o povo passou (atravessam com dificuldade). E os isrealitas louvaram ao Senhor (pronação/supinação, semelhante a palmas no sinal de libras). Para homens de fé (sinal de negativo realizado com a mão à frente do corpo, com os polegares apontados para baixo). Deus fecha os caminhos (braços abertos no primeiro momento e uma palma ao final, representando um movimento de fechar). O mar fechou (movimento de fechar com palma ao final), o povo se afogou (uma mão tapando o nariz e a boca, a outra mão totalmente estendida para cima, com agachamento).

Cláudia interrompe a música e diz que estão abaixando pouco para representar o "se afogou". Cláudia diz para todos dar as mãos de modo a formar um semicírculo, faz uma reflexão ao dizer que, desse modo, ao se afogar você morre, mas especialmente, se afogar você, afoga o irmão, ainda completa dizendo "é pra afogar o irmão aí". Com isso ela elege uma estratégia para fazer com que todos se abaixem com maior amplitude.

O mar fechou (eles praticamente só se moviam de um lado para o outro no ritmo da música, uma vez que as mãos dadas impediam um pouco a representação da coreografia dessa parte da canção), o Egito se afagou (e eles abaixavam muito; um deles, Vitor, chegou a colocar as mãos e os joelhos no chão, atrapalhando a representação dos que estavam ao seu lado e impedindo também a representação da parte seguinte da canção). O mar fechou (os que estavam do lado do Vitor o empurraram para que ele não se levantasse - enquanto isso muitos riam da situação). E os israelitas louvavam ao Senhor (Vitor finalmente conseguiu se levantar e os dançarinos pulavam de um lado para o outro levantando, quando possível, uma mão de cada vez, ou faziam a representação de dois tempos com as mãos pra cima ou pra baixo). E os Israelitas louvavam ao Senhor. O mar se abriu e o povo passou (todos correram para frente até se encontrarem no centro da capela). O mar se abriu e o povo passou (correram de costas até voltar à posição inicial). Ao fim da canção, fizeram uma onda com os braços, muitos sorriam e esperavam a hora certa para levantar cada um dos braços.

\section{h) Já chegou}

Antes de iniciar a música, havia três servas à frente e oito participantes, sendo duas mulheres e seis homens. Já chegou! Já chegou! (as mãos espalmadas realizam movimentos de pronação e supinação, enquanto os cotovelos flexionados em noventa graus movem-se alternadamente para frente e para trás) Espírito Santo já chegou! (o movimento descrito anteriormente continua, enquanto uma mão se encontra à frente do peito, a outra ao lado do quadril, além disso, um dos pés também se move, ora para frente e ora para trás) eu sinto em minhas mãos 
(realiza-se movimentos simultâneos de pronação e supinação de mãos com elas acima da cabeça), eu sinto em meus pés (movimentos simultâneos de pronação e supinação de mãos com elas abaixo do joelho), eu sinto em minh'alma e em todo o meu ser (os movimentos já citados de mãos acompanham o contorno do corpo da cabeça aos joelhos). Aquele que caminhou (vira-se para um dos lados, normalmente nessa hora observa-se para que lado a maioria das pessoas de sua linha de cadeira está virado, e caminha-se tranquilamente para um dos lados) sobre as águas (volta-se para a frente). Está aqui (salta para um dos lados, mas tem pessoas que saltam no mesmo lugar, algumas fazem isso, pois as pessoas de seus lados saltaram para o lado dela), está ao meu lado (salta-se para o lado oposto). Como um (uma mão acima da cabeça desenha um círculo no ar acima da pessoa que realiza) raio (a mão que se encontrava acima simula pegar algo no céu e lançar bruscamente ao chão), caindo sobre mim (as duas mãos acompanham o contorno do corpo da cabeça aos pés). Me queima, me queima, me queima (toca-se em vários lugares do corpo, como as laterais da cabeça, os ombros, as laterais dos quadris e os joelhos). Te queima, te queima, te queima (realizam-se os gesto de imposição de mãos e balançam-se as mãos no ritmo da música, alguns chegam a tocar os ombros, a cabeça de alguém ou, ainda tocar as mãos de outra pessoa como se tivesse batendo palmas).

\section{i) Na onda}

Eu vou na onda do amor, vou entrando nesta onda e me dar bem, eu vou (alguns batem palmas, outros realizam movimento de onda com a mão e o antebraço na horizontal). Eu vou pro lado de lá (as pessoas se deslocam andando, simulando uma corrida ou pulando para um dos lados, juntamente com a linha de sua cadeira), eu vou para o lado de cá (desloca-se para o outro lado). Eu vou pro lado de lá. Mergulhando de cabeça nessa onda de aprender amar (simula-se o nado do crawl com os braços, girando um braço e depois o outro).

Barbara pede para que os participantes formem duplas. Onde ele for, eu vou. Eu vou com meu Senhor (as duplas se deslocam pulando ou andando, pude perceber que alguns puxavam a outra pessoa forçando que ela se desloque). Ao final da música, Barbara diz que é uma missão muito importante rezar pelo irmão e conduz um momento de oração.

\section{j) O Senhor é rei}

Senhor é Rei, o Senhor é meu pastor e Rei (palmas batidas simulando a marcha com os pés). O Senhor está no céu (mãos acima da cabeça se movem de um lado para o outro), o Senhor está no mar (estendem os braços paralelos, à frente na altura do ombro e desenha-se um oito deitado - na verdade o símbolo do infinito - à frente, a fim de representar o movimento do mar), na extensão 
(uma das mãos, com a palma votada para a frente, desenha um semicírculo à frente, na altura do ombro) do infinito (aproveita-se o movimento anterior e com o indicador apontado para o céu, realizase o desenho de um círculo acima da cabeça). Está no céu (as mãos se agitam alternadamente acima da cabeça e ao mesmo tempo, as pessoas saltam), está no mar (braços estendidos paralelos à frente, na altura do ombro e desenha-se um oito deitado - na verdade o símbolo do infinito - à frente, a fim de representar o movimento do mar), na extensão do infinito (uma das mãos, com a palma votada para a frente, desenha-se um semicírculo à frente, na altura do ombro). Quando eu vacilar (move-se o quadril de um lado para o outro realizando leves agachamentos), eu não temerei (indicadores de um lado para o outro na altura dos ombros, a fim de sinalizar o não), pois o Senhor (indicadores apontados para o céu, com a mão elevada acima da cabeça) está comigo (polegares apontam para o peito).

\section{k) Passa fogo}

Vem, fogo vem, fogo vem (os participantes alternam o peso do corpo entre um pé e outro, balançando de um lado para o outro), fogo vem. Passa fogo (três palmas à frente na altura do peito) no meu braço agora (estende-se um dos braços com um movimento para frente e para o lado, fazendo-se com que a outra mão deslize na extensão de todo o braço), passa fogo no meu braço agora (mesmo movimento, só que do outro lado), passa fogo no meu braço agora, Oh senhor (mãos acima da cabeça balançando de um lado para o outro). Passa fogo (três palmas) na minha perna agora (mãos deslizadas na extensão de uma ou das duas coxas, de baixo para cima). Passa fogo na minha perna agora. Passa fogo na minha perna agora. Oh senhor. Passa fogo (três palmas) na minha cabeça (mãos sacodem ao lado da cabeça e alguns passam a mão sobre a cabeça). Passa fogo na minha cabeça. Passa fogo na minha cabeça. Oh senhor. Passa fogo (três palmas), no meu coração (as mãos espalmadas se agitam alternadamente à frente do peito). Passa fogo no meu coração. Passa fogo no meu coração. Oh! Senhor.

Vem, fogo vem, fogo vem, fogo vem, fogo vem (faz-se o movimento de chamar com a mão e com os braços estendidos acima). Eu disse, braço (braços estendidos ao alto), perna (mãos na coxa), cabeça (toca-se a cabeça) e coração (mãos sobre o peito). Braço, perna (alguns levantam somente uma dos joelhos à frente), cabeça e coração. Braço (os mais animados, com o mesmo movimento de braço, dá-se um passo para frente), perna (flexiona o quadril ao levantar um dos joelhos à frente), cabeça (tocando a cabeça, abaixa-se o joelho da perna que está levantada) e coração (com as mãos sobre o peito, dá-se um passo para trás).

Ao final, Lucas incentiva levantar os braços e pedir ao Espírito Santo trazer o fogo. E incentiva a oração. Depois conduz a um momento de reflexão ao som do violão. Ele começa a orar em línguas e todos assim fazem. 


\section{I) Quero louvar-te}

Quero louvar-te, sempre mais e mais. Buscar o Teu querer, Tua graça conhecer, quero louvar-Te (as pessoas batem palmas e realizam pequenos chutes para um lado e depois com a perna contrária para o outro). As aves do céu (braços estendidos ao lado do corpo e movimentados para cima e para baixo, simulando uma ave) cantam para ti (mãos em concha na lateral da boca), as feras do campo (com as mãos tendo os dedos semi-flexionados e afastados um dos outros - simulando garras - realiza-se um movimento em "c" no espaço à frente do peito, primeiro para cima, depois para frente e por fim para baixo) refletem Teu poder (mãos fechadas e abertas à frente do peito). Quero louvar (mãos para cima, deixando-as ainda na altura dos ombros), quero levantar as minhas mãos a $\mathrm{Ti}$ (mãos posicionadas acima da cabeça).

Paulo pede para aproveitar que as mãos estão para o céu e emitir uma oração de louvor a Deus.

\section{m) Templo vivo}

Seja (todos posicionados ao fundo do rincão e agachados) bem vindo Espírito Santo. O meu coração é o teu lar (bate-se palmas próximo ao chão até acima da cabeça, estendendo o quadril e os joelhos - de forma a ficar em pé - e ao mesmo tempo deslocando para frente, ao final agacha-se novamente). Seja bem vindo Espírito Santo (palmas próximo ao chão até em cima da cabeça, passando de agachado para de pé). A minha casa (de punho fechado, mas com polegar estendido, dirige-se o polegar ao peito) é também tua casa (de mão fechada, mas com o indicador estendido aponta-se para cima). A minha família (polegar ao peito) é o teu lugar (indicadores apontando para o céu), aaah (com as palmas da mão voltadas para frente, desenha-se um arco, começando da altura da cintura de um lado, passando por cima da cabeça até chegar àa altura da cintura do outro lado). Vem em mim morar (polegares das mãos apontam para o peito), aaah (com as palmas da mão voltadas para frente desenha-se um arco, começando da altura da cintura de um lado, passando por cima da cabeça até chegar na altura da cintura do outro lado). Quero ser o templo vivo (palmas) e te levar comigo (aponta-se para alguém com os dedos indicadores). Quero ser o templo vivo do teu amor (mãos sobrepostas sobre o coração, outros estendem os braços para o alto e ainda outros batem palmas).

\section{n) Tum-tum-tum de Deus}


É o amor de Deus, que mexe, que remexe, faz meu coração bater (parece que os participantes não sabem fazer a coreografia e ficam nas palmas, observando), tumtumtum (três palmas para um lado), tumtumtum (três palmas para outro lado). É o amor de Deus (desenha-se um coração no ar com o indicador), que mexe (agita-se o punho fechado à frente do corpo, inclinando-se o tronco à frente), que remexe (agita-se o punho fechado à frente da barriga, inclinando o tronco para trás), faz meu coração bater (mãos sobrepostas sobre o peito, afasta-as e encosta-as no peito novamente, simulando um batimento), tumtumtum (três palmas para um lado), tumtumtum (três palmas para outro lado). Nessa onda (faz-se o movimento de onda com uma das mãos inclinando o tronco para um dos lados) eu quero entrar (faz-se o movimento da onda com a outra mão inclinando o tronco para o lado oposto do anterior). Vou sem medo que Jesus vai ensinar (indicadores para o céu no ritmo da música, marchando com as pernas), a louvar, a louvar, a louvar (mãos balançadas em cima da cabeça, de um lado para o outro e as pernas continuam em simulação de marcha). Tiro, liro, liro, liro (requebra-se levemente o quadril, jogando-o de um lado para o outro e ao mesmo tempo realizando um leve agachamento) ah (volta-se para a posição natural, semelhante a ortostática, só que os braços são impulsionados para cima), a louvar, a louvar, a louvar (balança as mãos em cima da cabeça de um lado para o outro, simulando a marcha com as pernas).

É o amor de Deus, que mexe, que remexe, faz meu coração bater, tumtumtum, tumtumtum. Nessa onda eu quero entrar. Vou sem medo que Jesus vai ensinar. A pular, a pular a pular (alguns fazem três pulinhos para um lado - a-pu-lar- e três para o outro, outros levantam uma das pernas e fazem o pulinho característico do reggae, o ritmo da música lembra o reggae, mas a maioria só dá um pulo simples para cada lado). A confiar, a confiar (cada um fez uma coisa, uns simplesmente mantiveram o balanço do tronco no ritmo da música, outros abriam os braços em posição de cruz, alguns apontam para o céu, e outros colocam a mão no coração). Tiro, liro, liro, liro Ah. Confiar, confiar. Nessa onda eu quero entrar (Paulo faz um sinal para o ministério de música, este diminui a cadência da música). Vou sem medo que Jesus vai ensinar.

Paulo pede para que os participantes levantem os braços. Em seguida ele continua sem perder o tempo da música "A rezar, a rezar, a rezar". Paulo pede para por a mão no coração, dispensa os dois participantes que estavam representando à frente e novamente canta "a rezar, a rezar, a rezar". Paulo conduz uma reflexão sobre a oração e incentiva que as pessoas peçam a Deus que as ensinea rezar. Ele dá continuidade cantando "e Jesus vai me ensinar, a rezar a rezar a rezar, a louvar a louvar a louvar". Os participantes continuam com a mão no coração, a maioria embalados levemente pela música.

\section{o) Vai sacudir}


A Igreja vai buscar alegria no céu (gestos alternados com os braços, simulando o gesto de pegar algo, ou de chamar, abrindo e fechando a mão, acima da cabeça) e vai trazer aqui pra terra (com os cotovelos flexionados em noventa graus e as mãos pronadas, à frente do umbigo, faz-se extensão e flexão de punho, como se estivesse pedindo para abaixar, também agacha-se um pouquinho e gira de um lado para o outro, como se fizesse dois movimentos de flexão e extensão de punho de cada lado). E vai louvar, vai louvar, vai louvar (os braços balançam de um lado para o outro passando por cima da cabeça ao ritmo da música).

A Igreja vai buscar alegria no céu e vai trazer aqui pra terra. E vai dançar, vai dançar, vai dançar (faz-se o gesto característico de rock dos anos 1960).

Paulo pede ao ministério de música para que segurem o ritmo e as melodias sem o canto, e chama uma moça e homem para encenar a coreografia à frente. A Igreja vai buscar alegria no céu e vai trazer aqui pra terra. E vai dançar, vai dançar, vai dançar (os participantes simplesmente dão um passo de cada vez para cada um dos lados - direito e esquerdo - orientados pelo homem que está à frente, a moça faz o movimento de rock dos anos 60 mas parece fazer sozinha esse movimento). A Igreja vai buscar alegria no céu e vai trazer aqui pra terra. E vai pular, vai pular, vai pular (todos pulam, os dois que estão à frente parecem representar com mais afinco, as outras, nem tanto, algumas nem chegam a se desprender do chão). E vai louvar, vai louvar, vai louvar. E vai dançar, vai dançar, vai dançar (os homens e as duas pessoas que representam à frente pulam, algumas mulheres se embalam de um lado para o outro, duas nem sequer se mechem).

A Igreja vai buscar alegria no céu e vai trazer aqui pra terra. E vai rezar, vai rezar, vai rezar (as pessoas unem as palmas das mãos à frente do peito e seus corpos parecem estar embalados pelo ritmo da música). Vai abraçar, abraçar, abraçar (a metade abraça alguém que está ao lado).

Paulo pára a música e pergunta por que tem gente sozinha que não está representando o abraçar, e dá prosseguimento ao canto.

A Igreja vai buscar alegria no céu e vai trazer aqui pra terra. Vai abraçar, abraçar, abraçar (dessa vez todo mundo abraça alguém, até um menino que está sentado desde a hora que chegou com a sua mãe, abraça ela). E vai pular, vai pular, vai pular (nos desprendemos do braço para pular). E vai louvar, vai louvar, vai louvar. Vai cutucar, cutucar, cutucar (a maioria cutuca mais alguns ficam quietos - todas as pessoas quietas são mulheres que parecem estar sozinhas no encontro de sábado à noite - os dois que estão representando à frente, pulam muito nesse momento).

Paulo também observa haver pessoas que não estão se dedicando muito para cutucar, então ele pára, comenta o que ele reparou e pede para voltar à musica.

A Igreja vai buscar alegria no céu e vai trazer aqui pra terra. E vai louvar, vai louvar, vai louvar. E vai pular, vai pular, vai pular, vai cutucar, cutucar, cutucar (as pessoas mais quietas do 
fundo aumentam a amplitude do movimento). A Igreja vai buscar alegria no céu e vai trazer aqui pra terra. Vai abraçar, abraçar, abraçar. E vai rezar, vai rezar, vai rezar (e o casal que se encontra no fundo continua abraçado). E vai louvar, vai louvar, vai louvar.

O ministério da música diminui o ritmo da música e Paulo pede para deixar as mãos em cima para louvar a Deus ao tempo em que continua cantando "eu vou louvar, vou louvar, vou louvar". Ouve-se um pequeno balbúrdio gerado pelas falas egocêntricas. Paulo diz que na tristeza tem-se que louvar mesmo a Deus, porque na alegria é muito fácil e volta a cantar "eu vou louvar, vou louvar, vou louvar". Enquanto isso, os participantes continuam falando. Paulo, em seguida, conduz a um momento de reflexão sobre o louvor. Durante a dança dessa música, entram no auditório dois homens e três mulheres.

\section{p) Vamos cantar}

Vamos saudar, saudar na paz do meu Senhor Jesus (as pessoas se cumprimentam, geralmente dizendo "paz de Cristo", à medida que terminam de cumprimentar as pessoas ao redor, elas começam a bater palma no ritmo da música, algumas cumprimentam só uma pessoa e outras cumprimentam três ou mais). Deixar que o amor de Deus se torne em nossa vida Luz (Paulo segura o microfone com uma mão e simula palmas com a outra batendo em seu antebraço e os participantes continuam cumprimentando ou imitando Paulo nas palmas). É tão bom estar aqui (alguns param de bater palmas e ficam quietos sem saber o que fazer, enquanto Paulo continua sua simulação de palmas). Juntos louvando ao Senhor (braços livres para cima, balançando-os de um lado para o outro). Soltar a nossa voz (mãos livres ao redor da boca, depois amplia-a para frente e para os lados, desenhando as laterais de um triângulo à frente da boca) e assim (braços relaxados na lateral do corpo) exaltar o Deus de amor (mãos em direção ao céu, estando elas abertas e suas palmas voltadas para cima). Paulo diz "só vocês, vamos saudar". Barbara inicia, vamos saudar, saudar na paz do meu senhor Jesus (alguns batem palmas, inclusive Paulo, mas a maioria dos participantes nada fazem, parecem perdidos). Paulo se vira para o ministério de música e diz "segurou" fazendo um gesto de pare com a mão espalmada.

Paulo se certifica que os participantes sabem a letra da música, pede para que cantem mais forte e puxa a música do início. Parece que deu certo, as pessoas estão cantando. Vamos saudar, saudar na paz do meu Senhor Jesus (palmas). Deixar que o amor de Deus se torne em nossa vida Luz (palmas). É tão bom estar aqui. Juntos louvando ao Senhor (braços livres para cima, balançandoos de um lado para o outro)

\section{q) Vira de Jesus}


Vocês porque vieram (as pessoas só cantam, um moço aponta para a moça que veio com ele), viemos louvar ao Senhor (mãos acima da cabeça, balançando-as de um lado para o outro). Aleluia, aleluia, glória e louvor ao Senhor (mãos acima da cabeça, balançando-as de um lado para o outro).

Barbara pede para os blocos de pessoas posicionados nos bancos, que se virem de frente um para o outro. Barbara explica que um bloco pergunta, e o outro responde e depois a situação se inverte. Vocês por que vieram (aí sim, todos apontam a mão ou os dedos às pessoas à frente), viemos louvar ao Senhor (mãos acima da cabeça, balançando-as de um lado para o outro).

Todos juntos: Aleluia aleluia, glória e louvor ao Senhor (mãos acima da cabeça, balançando-as de um lado para o outro). Barbara pede para os homens sentarem-se, e diz que é a vez das mulheres. As mulheres por que vieram (ninguém faz nada), viemos louvar ao Senhor. Aleluia aleluia, glória e louvor ao Senhor (mãos acima da cabeça, balançando-as de um lado para o outro, observa-se um trio, movendo os braços conforme a pronúncia das palavras, ao falar aleluia, fazem mais devagar e combinam o mesmo lado, ao falar glória e louvor ao Senhor, fazem rapidamente).

Barbara pede para as mulheres sentar e os homens se levantar. Barbara pede para os homens perguntar as mulheres. Enquanto os homens falam, as mulheres permanecem sentadas, na hora de que precisam responder as perguntas, elas se levantam e os homens permanecem em pé.

Agora os homens sentam e as mulheres perguntam para eles. Os homens por que vieram, viemos louvar ao Senhor. Aleluia aleluia, glória e louvor ao Senhor (percebe-se que no bloco contrário ao que se posiciona o trio, algumas moças copiam o modo de mover os braços do trio). Barbara chama à frente todos os servos do Ágape e diz que os participantes vão perguntar aos servos.

Os servos por que vieram? Viemos louvar ao Senhor. Aleluia, aleluia (uma serva faz uma coreografia diferente, faz pronação e supinação de punho com o punho à altura do ombro, com uma mão para o primeiro "aleluia" e com a outra mão para o segundo), glória e louvor ao Senhor (ela balança as mãos acima da cabeça, de um lado para o outro, sem fazer pronação ou supinação). Quando a situação se repete, cinco pessoas a imitam na nova coreografia.

Barbara agradece a presença dos servos, pede para levantar os braços, fechar os olhos, soltar a voz e louvar a Deus. Barbara conduz o momento de oração.

\section{r) Vitória no deserto}

Quando a noite fria cair sobre mim (de punhos fechados e braços cruzados, faz-se um " $x$ " sobre o peito e um passo para um lado e depois para o outro é dado) nánáná (alguns movimentam ligeiramente o quadril de um lado para o outro ao realizar um leve agachamento), e o deserto eu 
encontrar (abana-se com as mãos o pescoço, como se tivesse sentindo calor). Me ver cercado por egípcios e por faraós (dedo indicador apontando para o céu, simulando círculos), óhóhóhs (palmas das mãos unidas a cima da cabeça e movimentos laterais com a cabeça), que me impediam de prosseguir (sinal de pare com as duas mãos à frente do corpo).

Dada uma pausa na música, Barbara diz que diretamente do retiro de música, eles trouxeram uma nova coreografia, e propõe que os outros imitem ela e Claudia. Sei que o teu fogo (mãos com a palma voltada para frente, fazendo repetidamente flexões de punho de acordo com o tempo da música, as mãos saem da esquerda e vão para a direita passando por cima da cabeça, como um arco) cairá sobre mim (faz-se o movimento contrário do arco batendo palmas, da direita para a esquerda, passando por cima da cabeça, no tempo da música) e me levará (polegares apontando para o peito) em ti confiar ah ah (indicadores apontando para o alto). Então eu direi, então eu direi (mãos em cunha ao redor da boca), ôhôh (mãos balançando ao céu), abra-se o mar (as mãos se juntam à frente do corpo e depois se separam como se estivesse abrindo um espaço à frente). $\mathrm{E}$ eu passarei pulando e dançando em tua presença (pula girando para um lado, agitando os braços para cima e para baixo, à frente do umbigo e depois realiza-se o mesmo movimento do outro lado, cerca de três vezes cada lado, até dar o fim do tempo da sentença na música). Por isso, eu danço, danço, danço na presença do Rei (as pessoas fazem um passo de dança muito conhecido no rock e usado por muitos cantores brasileiros da década de 1960, destaca-se aqui Cely Campelo em sua música estúpido cupido, em que a cantora, joga os quadris para um lado e para o outro, fazendo movimentos de vai e vem com os braços. Por isso eu cutuco tucotucotucotuco na presença do Rei (os servos se viram ou abrem os braços para cutucar os ombros ou a barriga dos outros, quando o cutucão é na barriga, a reação de quem recebe é mais exagerada, de proteção da barriga causado por uma possível dor, cócega ou encenação mesmo). Por isso abraço, abraço, abraço, abraço na presença do Rei (todos colocam as mãos nas costas um do outro, formando um grande semicírculo, pois aparentemente não se pode dar as costas para o sacrário, e pulam enquanto se abraçam). Por isso eu sorrio, rio, rio na presença do Rei (as pessoas ainda abraçadas e pulando, alguns cantam, outros abrem um sorriso e alguém encena dizendo háháhá, uns olham para os outros, talvez para conferir se estão sorrindo ou apenas para sorrir para alguém). Então eu direi (todos se soltam para colocar a mão em cunha, ao redor da boca). Bárbara diz "Amém!!!" e todos batem palmas, e alguns gritam "êêêê" enquanto batem palmas.

Durante a música, muitos olham um para o outro, às vezes tem-se a impressão que eles querem competir um com o outro, ver quem faz mais graça, ou quem faz a amplitude do movimento maior. Às vezes, quem agita os braços à frente do umbigo com mais agilidade. Nem sempre eles são respondidos com movimentos, na maioria das vezes, são sorrisos. O Coordenador do Grupo, Pedro, é o que mais faz graças com movimentos e, sempre as pessoas sorriem. 
Nota-se que todos estão muito descontraídos, às vezes se soltando mais na amplitude ou no olhar para o outro e fazendo caretas, que devem significar que estão gostando do que estão fazendo. Nota-se também que na maioria das vezes uma amplitude maior, a criação de um movimento, um atraso ou uma aceleração no passo em relação ao tempo da música, vem quando um está olhando para o outro. Nota-se ainda duas exceções, o coordenador do grupo que é muito entrosado, e Lucas aparentemente menos entrosado. A impressão é que o coordenador tem certeza que estão olhando para ele (e de fato, sempre tem ao menos um olhando para ele, talvez esperando alguma graça) e que o Lucas faz isso para não se sentir tão excluído do grupo, uma vez que todos fazem uma graça de vez em quando. Ainda quanto ao Lucas, de vez em quando, alguém olha para ele, apesar de que ele não retém o olhar mais assíduo de alguém, se está em círculos, então, com toda certeza alguém olha para ele, talvez "suas graças" sejam direcionadas ao grupo como um todo, para que todos sintam que ele está igualmente inserido ali, como também para que ele próprio não se sinta estranho no grupo (, portanto, igualmente inserido. Apesar de estar bem claro para mim que, na homogeneidade do grupo, ele é um, para não dizer o mais, excluído.

Quanto a mim, eu não fazia movimentos exagerados, tentava manter um padrão linear na minha dança, que era cada vez mais incentivada quando eu notava alguém criando ou exagerando nos movimentos. Ao ver que alguém olhava diretamente para mim, eu sentia vergonha por não saber a letra da música, e com toda certeza minha expressão facial era modificada com uma careta ou com o sorriso enquanto a dança se mantinha.

\section{t) Vontade de louvar}

Esse braço que não me dá (parados, braços estendidos para cima), nenhuma vontade de louvar (braços caem totalmente relaxados e inclina-se o corpo um pouco à frente para ver que os braços estão pendidos). Espírito Santo vem renovar (os braços se estendem aos céus) - a música que se encontrava em uma cadência muito lenta somente com o teclado, aumenta seu ritmo e mais instrumentos entram compondo a música. Para que se mova daqui para lá (balançam os braços por cima da cabeça de um lado para o outro, dando um passo para um lado e depois para o outro). Para que se mova daqui para lá (alguns fazem dois para lá e dois para cá com as pernas e com os braços no ritmo da música) - alguns instrumentos silenciam e a cadência diminui novamente.

Essa perna que não me dá (balança uma das pernas à frente), nenhuma vontade de louvar (a maioria continuou o movimento anterior, alguns fizeram não com o indicador apontando-o para cima e balançando os braços de um lado para o outro). Espírito Santo vem renovar (mãos para cima, da altura da cabeça, alguns deslizam acompanhando o comprimento do corpo de cima a baixo) - a cadência da música aumenta, assim como a quantidade de instrumentos. Para que se mova daqui acolá lá (alguns balançam essa perna de um lado para o outro, Bárbara pula de um lado para o outro 
e a maioria assim o faz; um trio de meninas mais ao fundo combina uma coreografia diferente, um moço à frente coloca as duas mãos para trás, na lombar e move um pé à frente depois atrás, continuamente). Essa cabeça que não me dá (uma ou as duas mãos tocam a fronte ou as laterais da cabeça), nenhuma vontade de louvar, Espírito Santo vem renovar (mãos para o alto).

Barbara interrompe a música e diz que é para pedir bênçãos ao irmão. Então todos direcionam as mãos à cabeça de alguém, realizando-se assim a imposição de mãos. Para que se mova daqui acolá. Esse corpo que não me dá (alguns movem os quadris de um lado para o outro), nenhuma vontade de louvar (ninguém faz nada). Barbara pára a música e diz que quando não se quer fazer nada com o corpo, normalmente senta-se ou deita-se. Então, ela diz que todos podem ficar à vontade e retorna a música.

Esse corpo que não me dá (a maioria senta), nenhuma vontade de louvar. Espírito Santo vem renovar (todos se levantam com as mãos erguidas acima da cabeça e fazendo o movimento de chamar com as mãos, outros colocam a mão acima da cabeça e descem tendo-as acompanhando o contorno do corpo).

Barbara diz que vai fazer novamente e que quando for chamar o Espírito Santo, deve-sedar um pulo da cadeira. Esse corpo que não me dá (dessa vez todos sentam), nenhuma vontade de louvar. Espírito Santo vem renovar (a maioria pula). Para que se mova daqui acolá, (Barbara pede muita criatividade antes de iniciar essa frase, e observa-se uma diversidade de passos, mais dá a metade faz o movimento já relatado, o trio de moças é o que mais diversifica, elas estendem os braços à frente e no decorrer da música fazem um movimento de onda com ambos, enquanto o tronco acompanha, e à medida que o movimento vai fluindo, elas se deslocam para trás e para a lateral).

Barbara diz que a mensagem da música é de não deixar o corpo manipular-se e impedir assim de ir até Deus, de ir à Igreja e de ir à missa. Dá o primeiro passo e pede ao Espírito Santo. Barbara pede para olhar nos olhos do irmão e conversar, perguntar pelo motivo que o trouxera ali. 